\title{
Organic-walled microphytoplankton assemblage of the Middle Devonian (Givetian) Arkona, Hungry Hollow and Widder formations, Ontario, Canada: biostratigraphic and palaeogeographic significance
}

\author{
R. Wicander ${ }^{(1,2)}$ and G. Playford ${ }^{(2)}$ \\ (1) Department of Earth and Atmospheric Sciences, Central Michigan University, Mount Pleasant, Michigan, U.S.A. 48859. \\ wican1r@cmich.edu \\ (2) School of Earth and Environmental Sciences, The University of Queensland, Brisbane, Q 4072, Australia. \\ g.playford@uq.edu.au
}

\begin{abstract}
A diverse and abundant organic-walled microphytoplankton assemblage, consisting of 49 species of acritarchs, prasinophyte phycomata and chitinozoans, was recovered from a $13.3 \mathrm{~m}$-section of the Middle Devonian (Givetian) Arkona, Hungry Hollow and Widder formations at Hungry Hollow, Ontario, Canada. Close similarity exists between this assemblage and others described previously from the Givetian of North America. Marine palynofloras of comparable age from elsewhere in North America share between $59-96 \%$ of the species identified in the present assemblage, thus testifying to its stratigraphic-correlative applicability in a regional context. Species widely occurring in North America and typically Givetian (although not restricted therein) include: Arkonites bilixus, Cymatiosphaera canadense, Diexallophasis simplex, Duvernaysphaera angelae, D. tenuicingulata, Estiastra rhytidoa, Exochoderma arca, Gorgonisphaeridium inflatum, Hapsidopalla chela, Leiofusa pyrena, Muraticavea munifica, Oppilatala sparsa, Palacanthus ledanoisii, Polyedryxium ambitum, Staplinium cuboides, Tyligmasoma alargada, Uncinisphaera acantha, Veryhachium pastoris, Villosacapsula compta and V. rosendae. Palaeogeographically, Middle Devonian organic-walled microphytoplankton taxa display a conspicuous degree of cosmopolitanism, with many species shared with Laurasia (Laurentia, Avalonia, Baltica), Gondwana (principally Argentina, Ghana, Libya, Algerian Sahara, Western Australia) and Kazakhstan (northwestern China).
\end{abstract}

Keywords: Acritarchs, Givetian, Canada, biostratigraphy, palaeogeography.

\section{Asociaciones de micropláncton de pared orgánica del Devónico Medio (Givetiense) de Arkona, formaciones Hungry, Hollow y Widder, Ontario, Canadá: significado bioestratigráfico y paleogeográfico}

\author{
RESUMEN
}

Una asociación diversa de micropláncton de pared orgánica con gran abundancia de ejemplares, que está integrada por 49 especies de acritarcos, ficomas de prasinofitos y quitinozoos, fue obtenida en los materiales de la sección de 13,3 m de potencia del Devónico Medio (Givetiense) de Arkona, formaciones Hungry, Hollow y Widder, Ontario, Canadá. Esta asociación es muy parecida a otras que previamente se describieron en el Givetiense de Norte América. Algunas palinofloras marinas de otras partes de Norte América presentan asociaciones compuestas por un 59-96\% de las especies que se estudian en este trabajo. De este modo, se pone de manifiesto su aplicación estratigráfica y de correlación en un contexto regional. Entre el conjunto de especies norteamericanas y típicamente givetienses (aunque no se encuentran restringidas a esta edad) identificadas están: Arkonites bilixus, Cymatiosphaera canadense, Diexallophasis simplex, Duvernaysphaera angelae, D. tenuicingulata, Estiastra rhytidoa, Exochoderma arca, Gorgonisphaeridium inflatum, Hapsidopalla chela, Leiofusa pyrena, Muraticavea munifica, Oppilatala sparsa, Palacanthus ledanoisii, Polyedryxium ambitum, Staplinium cuboides, Tyligmasoma alargada, Uncinisphaera acantha, Veryhachium pastoris, Villosacapsula compta y V. rosendae. Paleogeográficamente, los taxones microplanctónicos de 
Wicander, R. and Playford, G., 2017. Organic-walled microphytoplankton assemblage... Boletín Geológico y Minero, 128 (4): $839-883$

pared orgánica del Devónico Medio que hemos identificados, son cosmopolitas en un alto grado, con muchas especies distribuidas por Laurasia (Laurentia, Avalonia, Báltica), Gondwana (principalmente Argentina, Ghana, Libia, el Sahara argelino, el Oeste de Australia) y Kazakhstan (noroeste de China).

Palabras clave: Acritarcos, Givetiense, Canadá, bioestratigrafía, paleogeografía.

\section{VERSIÓN ABREVIADA EN CASTELLANO}

\section{Introducción}

El registro publicado sobre las asociaciones de micropláncton de pared orgánica del Devónico Medio (acritarcos y ficomas de prasinofitos) es menos conocido de lo que puede ser esperado. Muchos de los trabajos, especialmente los más antiguos sobre el tema, no tienen una estratigrafía precisa y/o son inadecuados desde un punto de vista taxonómico y de la ilustración de los taxones. Además, las asociaciones inferidas simplemente se atribuyeron al Devónico Medio sin considerar los pisos Eiffeliense y Givetiense. Afortunadamente, las publicaciones más reciente tienden a presentar una mejor documentación estratigráfica y una sistemática e ilustración de los taxones mucho más precisa. En relación con esto, se han mejorado las interpretaciones bioestratigráficas y paleogeográficas.

El estudio de una palinoflora del Devónico Medio (Givetiense) del suroeste de Ontario (Canadá) presenta una interesante estimación taxonómica de una asociación microplanctónica bien conservada y diversa de acritarcos y prasinofitos. La identificación de los taxones que la integran facilita su comparación con otras palinofloras de edad similar tanto norteamericanas como de otras partes del mundo. De esta manera, se incrementa el conocimiento de la distribución de las palinofloras planctónicas de pared orgánica del Devónico Medio.

\section{Metodología}

Se recogieron catorce muestras en los materiales de 13,3 $m$ de potencia de edad Givetiense de las formaciones Arkona, Hungry Hollow y Widder que están situadas a lo largo del banco norte del río Au Sable en Hungry Hollow (Ontario, Canadá) (Figs. 1-2). Todas las muestras tuvieron contenido palinológico, aunque sus asociaciones presentaron diferente grado de preservación, abundancia y diversidad de taxones.

En esta localización, la Formación Arkona está compuesta por 6,8 $\mathrm{m}$ de pizarras con un nivel delgado de limestones arcillosos cerca de su techo. La Formación Hungry Hollow que se encuentra de forma disconforme por encima de la anterior, muestra 0,5 $\mathrm{m}$ de limestones cristalinos seguidos por $1 \mathrm{~m}$ de niveles calizos muy fosilíferos. Por encima de la anterior, de forma conforme o disconforme, está la Formación Widder (la que se encuentra en la parte más superior en esta localidad) que es una unidad fosilifera de unos 5 metros de niveles carbonáticos con intercalaciones de limestones y de limestones arcillosos.

Las tres formaciones mencionadas comprenden la mitad de las que constituyen el Grupo Hamilton del sur de Ontario (Fig. 3). Estas seis formaciones en orden estratigráfico ascendente son las de Bell, Rockport Quarry, arkona, Hungry Hollow, widder e Ipperwash , y están principalmente constituidas por mudstones y pizarras con delgadas y persistentes unidades carbonáticas laterales. Los materiales de las seis están atribuidos al Givetiense a partir de relaciones estratigráficas y evidencias de faunas de invetebrados (Stumm et al., 1956; Driscoll et al., 1965; Boneham 1967a,b; Mitchell, 1967; Winder and Sanford, 1972; Legault, 1973; Uyeno et al., 1982; Landing and Brett, 1987; Johnson et al., 1992).

Las catorce muestras que representan todas las litologías recogidas en Hungry Hollow, fueron procesadas usando las técnicas palinológicas tipo. Las láminas fueron preparadas a partir de los residuos resultantes después de filtrarlos a través de tamices de 52 y 20 m. Se realizó una contabilización de los diferentes taxones que se encontraron en cada muestra realizándose una tabulación de las abundancias de palinomorfos.

\section{Resultados}

Las asociaciones microplanctónicas obtenidas en la localidad de Hungry Hollow están integradas por 49 taxones: 32 de acritarcos (27 especies y cinco mencionadas informalmente, que se han asignado a 25 géneros), 16 de prasinofitos (14 especies y dos que se han dejado en nomenclatura abierta, pertenecientes a nueve géneros) y uno de quitinozoos. Adicionalmente se han encontrado otros quitinozoos, escolecodontos, miosporas y partículas amorfas de kerógeno en proporciones variables, pero no se han identificado.

Los ficomas de prasinofitos están encuadrados en la Clase Prasinophyceae Christensen, 1962 y las espe- 
Wicander, R. and Playford, G., 2017. Organic-walled microphytoplankton assemblage... Boletín Geológico y Minero, 128 (4): $839-883$

cies identificadas se han ordenado considerando los géneros a los que pertenecen. Los acritarcos se han tratado como géneros y especies-forma siguiendo las normas del Código Internacional de Nomenclatura para algas, hongos y plantas (ICN: McNeill et al., 2012), y también se han ordenado alfabéticamente bajo el informal Grupo Acritarcha Evitt, 1963. Los quitinozoos se han consignado en el Orden Operculatifera Eisenack, 1931.

En la lista de sinonimias de cada especie, se indica la designación binomial (basiónimo) de cada una de ellas así como cualquier transferencia genérica que se haya realizado. Además, se señalan las especies tipo de cada género. Cuando nos pareció apropiado, se incluye la referencia completa de una sinonimia. En donde ha sido posible, se han documentado observaciones y comparaciones sobre cada especie, así como su presencia en cada una de las muestras estudiadas. La distribución estratigráfica y geográfica de cada especie se señala de en la sección denominada registros previos.

Los acritarcos dominan numéricamente la palinoflora tanto a nivel genérico como específico $183 \%$ y $67 \%$, respectivamente). Los taxones más comunes de acritarcos y prasinofitos se encuentran regularmente a lo largo de la sección muestreada. Excluyendo a las leiosferas y a los tasmanítidos, las cinco especies más abundantes son en orden decreciente: Multiplicisphaeridium ramusculosum, Navifusa bacilla, Duvernaysphaera tenuicingulata y D. angelae. Los cinco taxones hallados en menor número, en orden también decreciente y cuantitativo, son: Arkonites bilixus, Solisphaeridium sp. A, Tyligmasoma alargada, Cymatiosphaera cornifera y Diexallophasis simplex. La presencia a lo largo de la sección del resto de los taxones identificados oscila de raro a muy abundante.

Numerosos estudios fundamentados en los principios modernos de la Sedimentología, Biología y de la relación físico-química de las aguas marinas, junto con los análisis sedimentológicos de facies, los de asociaciones de invertebrados así como la distribución de fitopláncton y de esporas/polen, han sido utilizados para analizar paleoambientes. Particularmente, la pequeña talla y durabilidad de los palinomorfos son de una gran ayudar para realizar tales interpretaciones. Además, las fluctuaciones en la relación inversa entre el micropláncton marino y las esporas-polen derivados de las zonas continentales están bien establecidas y se usan de forma general para determinar la extensión de las paleolíneas de costa, y el reconocimiento de ciclos transgresivos/regresivos.

Varios modelos basados en la diversidad del microfitopláncton, la composición de las asociaciones y las clases de morfotipos se han propuesto para interpretar y reconocer paleolíneas de costa, medios cercanos y alejados a la orilla, profundidades y ciclos transgresivos/regresivos. Los estudios basados sobre estos modelos y los principios previamente articulados están en general de acuerdo cuando se aplica a interpretaciones paleoambientales.

El uso de estos principios generales de síntesis paleoambiental, litologías y fauna invertebrada asociada, claramente indica que las formaciones Arkona, Hungry Hollow y Widder fueron depositadas en un medio marino normal de baja energía, alejado de la costa. Además, la palinoflora obtenida confirma esta interpretación paleoambiental.

Cambios en la diversidad y abundancia de las asociaciones de Arkona/Hungry Hollow/Widder están en consonancia con los ciclos transgresivos/regresivos litológicamente inferidos. Además, la composición de las asociaciones es también indicativa de un medio marino rocoso alejado de la costa.

Teniéndolos en cuenta de forma conjunta, los factores citados anteriormente denotan que los sedimentos de las formaciones Arkona, Hungry Hollow y Widder se acumularon en medios marinos bien oxigenados, alejados de la costa. Además, esto se encuentra ejemplificado por las asociaciones palinológicas que se encontraban asociadas a sedimentos de grano fino, con regresiones periódicas que promovían el desarrollo de limestones coralinos de grano grueso dentro de un medio arrecifal.

Comparaciones de las palinofloras Arkona/Hungry Hollow/Widder con asociaciones abundantes, diversas y bien conservadas del Devónico Medio de otras seis localidades de Norte América (Figs. 4-5), muestran apreciables similitudes (aproximadamente un $59-60 \%$ de taxones en común). Esto no debe sorprendernos y, a causa de la proximidad geográfica, encontramos un alto porcentaje de taxones en común (89\%) en el Grupo Hamilton del suroeste de Ontario. Lo mismo puede ser observado en el Givetiense de Dolomite Boyle (Kentucky) en donde hay un $96 \%$ de elementos en común.

El número sustancial de especies de acritarcos/prasinofitos que podemos encontrar en las siete asociaciones norteamericanas mencionadas es claramente sintomático de una entidad palinostratigráfica devónica que posibilita una correlación estratigráfica con el paleocontinente de Laurentia.

Aunque se han publicado numerosos estudios de asociaciones microplanctónicas de pared orgánica fuera de Norte América, muchas de estas son inaceptables para hacer comparaciones a causa de una o varias limitaciones, esencialmente, un insuficiente control estratigráfico, una pobre preservación de los palinomorfos, y una inadecuada documentación sistemática o de ilustración. No menos de doce asociaciones de Sudamérica, África, Europa, Australia y China poseen el criterio necesario para realizar una comparación significativa con la asociación de Ontario. El grado de parecido de estas asociaciones oscila entre el $12 \%$ de los taxones (Cuenca de Canning, Oeste de Australia) y más de un 77\% (Cuenca de Junggar, Xinjiang, China).

Durante el Devónico Medio (Fig. 6), Laurentia se encontraba en latitudes bajas, entre unos $30^{\circ} \mathrm{N}$ y $30^{\circ} \mathrm{S}$. 
Wicander, R. and Playford, G., 2017. Organic-walled microphytoplankton assemblage... Boletín Geológico y Minero, 128 (4): $839-883$

Las asociaciones bien conservadas y estratigráficamente delimitadas de acritarcos/prasinofitos del Devónico Medio que se discuten en este trabajo son, en un alto grado, cosmopolitas. Aunque un buen número de taxones se encuentran predominantemente en Laurentia, la mayoría de las especies muestra una dispersión por todo el mundo durante el Devónico Medio. Por último, algunas especies como Maranhites brasiliensis, M. mosesii, Pterospermella pernambucensis, Umbellasphaeridium deflandrei y U. saharicum, fueron endémicas de regiones de latitudes altas de Gondwana y estuvieron ausentes en latitudes bajas y medias hasta el Devónico tardío.

\section{Conclusiones}

La asociación diversa y bien conservada de acritarcos/prasinofitos obtenida en los 13,3 m de exposición que presentan los materiales del Devónico Medio (Givetiense) de las formaciones Arkona, Hungry Hollow y Widder (Hungry Hollow, suroeste de Ontario, Canadá), está compuesta por 49 especies (32 acritarcos, 16 prasinofitos y 1 quitinozoo).

La edad givetiense de la asociación estudiada está confirmada por los rangos estratigráficos de ciertas especies de acritarcos y prasinofitos que se habian identificado previamente en otras bien delimitadas biostratigráficamente en Norte América y otras regiones.

La composición de la palinoflora indica una deposición de los sedimentos que la contiene en un medio marino y rocoso, bien oxigenado y alejado de la costa con periódicas regresiones que se producían por el desarrollo de medios de tipo arrecifal.

La asociación de microfitopláncton de pared orgánica de Arkona/Hungry Hollow/Widder es altamente cosmopolita, y solo contiene un conjunto pequeño de especies que se encontraban confinadas en Norte América.

La distribución paleogeográfica global de las especies del Devónico Medio confirma la existencia de un componente endémico de latitudes altas de Gondwana. Muchas de sus especies no se dispersaron a latitudes bajas o medias hasta el Devónico tardío.

\section{Introduction}

Acritarchs and prasinophyte phycomata (collectively termed organic-walled microphytoplankton) of the Middle Devonian (Givetian) Arkona, Hungry Hollow and Widder formations of the Hamilton Group have previously been reported from the subsurface by Legault (1973). Although not extensively studied, Middle Devonian phytoplankton assemblages have also been reported from elsewhere in North America by Baschnagel (1942), Deunff (1954, 1955, 1961, 1966a, 1971), Audretsch (1967), Peppers and Damberger (1969), Nautiyal (1975), Playford (1977), Wicander and Wood (1981, 1997), Wicander (1983, 1984), Wicander and Wright (1983), Wood and Clendening (1985) and Huysken et al. (1992).

Several of these papers are only of historical interest, and neglible for biostratigraphic correlation. The first record of North American Middle Devonian acritarchs is that of Baschnagel (1942), who described and illustrated several taxa from cherts of the Onondaga Formation in the Syracuse area of New York State. His specimens are from thin sections only and are poorly preserved.

Acritarchs recovered from sediment within the corallum of the tabulate coral Favosites turbinata, provided the basis of a series of papers by Deunff (1954, 1955, 1961, 1966a, 1971). Although Deunff named many new species, there is uncertainty as to the stratum and geographic location of the coral specimen, thus limiting the biostratigraphical usefulness of his papers.

Audretsch (1967) briefly described and illustrated six acritarch species from the Givetian Pine Point Formation, Great Slave Lake area, Northwest Territories. Peppers and Damberger (1969) recorded Leiospheridia sp., Tasmanites huronensis and Stellinium octoaster ( $=S$. micropolygonale) from the lower Givetian Davenport Limestone Member of the Wapsipinicon Formation, Illinois. Lastly, Nautiyal (1975) reported, and illustrated, a number of previously named organic-walled microphytoplankton species from the subsurface Givetian Elk Point Group of Saskatchewan and Alberta.

The other papers listed above, all document reasonably well preserved and diverse suites of Middle Devonian acritarchs and prasinophyte phycomata with reliable stratigraphic control. These assemblages are analyzed and discussed in subsequent sections as they relate to Middle Devonian biostratigraphy and palaeogeography.

\section{Stratigraphy and correlation}

Fourteen samples for this study were collected from a $13.3 \mathrm{~m}$-exposure of the Givetian-age Arkona, Hungry Hollow and Widder formations along the north bank 
of the Au Sable River at Hungry Hollow, Ontario, located ca $3 \mathrm{~km}$ northeast of Arkona (Fig. 1). These samples (Fig. 2) were subsequently processed for palynomorphs.

At this site, the Arkona Formation (sometimes referred to as the Arkona Shale) consists of $6.8 \mathrm{~m}$ of bluish-gray to gray shale with a thin argillaceous limestone bed near its top. Disconformably overlying the Arkona, is the $1.5 \mathrm{~m}$-thick Hungry Hollow Formation, comprising $0.5 \mathrm{~m}$ of blue-gray, coarsely crystalline limestone, succeeded by $1.0 \mathrm{~m}$ of richly fossiliferous, gray, calcareous shale. Either conformably or possibly disconformably, the Hungry Hollow Formation is overlain by the Widder Formation, a $5 \mathrm{~m}$-thick unit of fossiliferous, gray, calcareous shale with interbeds of limestone and argillaceous limestone.

The Hamilton Group in southern Ontario (Fig. 3) consists mostly of mudstones and shales, with thin, laterally persistent carbonate units. It is divided into six formations that, in ascending stratigraphic order, are: the Bell, Rockport Quarry, Arkona, Hungry Hollow, Widder and Ipperwash formations (Stumm et al., 1956; Boneham, 1967a; Legault, 1973; Johnson et al., 1992; Armstrong and Carter, 2006). Based on invertebrate faunal evidence (e.g. corals, brachiopods, trilobites, crinoids) and stratigraphic relationships, all six formations are considered Givetian in age (Stumm et al., 1956; Driscoll et al., 1965; Boneham, 1967a, b; Mitchell, 1967; Winder and Sanford, 1972; Legault, 1973; Uyeno et al., 1982; Landing and Brett, 1987; Johnson et al., 1992).

The Hamilton Group of Ontario correlates with the middle part of the more arenaceous Hamilton Group of New York State, and with the calcareous Traverse Group of the Michigan Basin (Uyeno et al., 1982; Johnson et al., 1992). In Ohio, the Plum Brook and Silica formations, along with the Olentangy Shale, are correlative with the Arkona Formation (Driscoll et al., 1965; Bartholomew and Brett, 2007; Brett et al., 2011), and the Ten Mile Creek Formation is considered stratigraphically equivalent to the Hungry Hollow Formation (Sandford, 1967).

\section{Materials and methods}

The fourteen samples collected and prepared for palynologic analysis represent all of the lithotopes of the three aforementioned formations (Fig. 2).

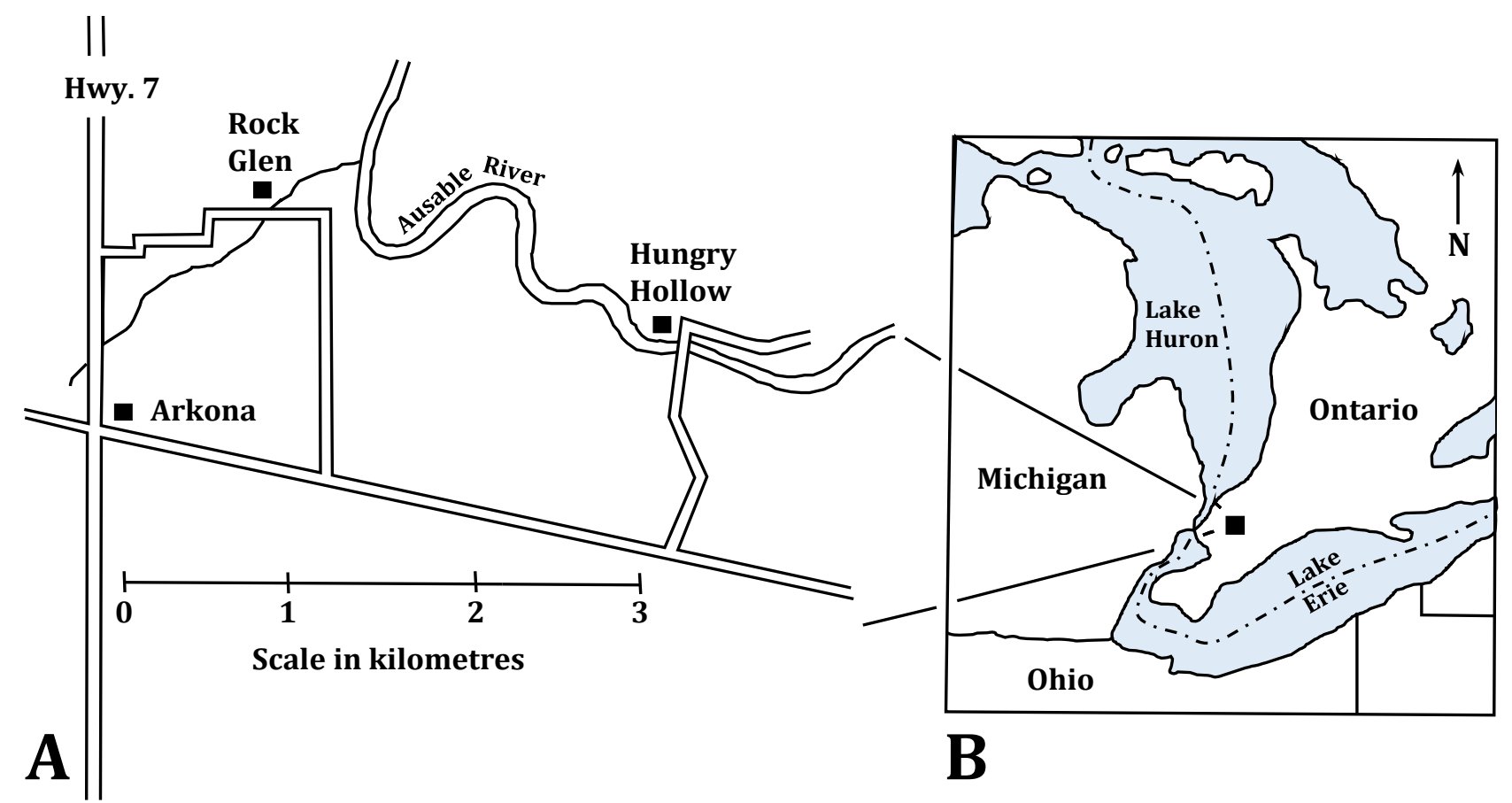

Figure 1. A. Hungry Hollow locality where 14 samples from the Middle Devonian (Givetian) Arkona, Hungry Hollow and Widder formations were collected from an exposure along the north bank of the Au Sable River. B. Generalized map of southwestern Ontario, Canada, with the location of the Hungry Hollow collecting site indicated by a solid square.

Figura 1. A. Localidad de Hungry Hollow donde se tomaron catorce muestras del Devónico Medio (Givetiense) de las formaciones Arkona, Hungry Hollow y Widder, en una zona expuesta a lo largo del banco norte del Río Au Sable. B. Mapa general del sur de Ontario (Canadá), con la localización del lugar de recogida de muestras en Hungry Hollow indicada por un cuadrado. 


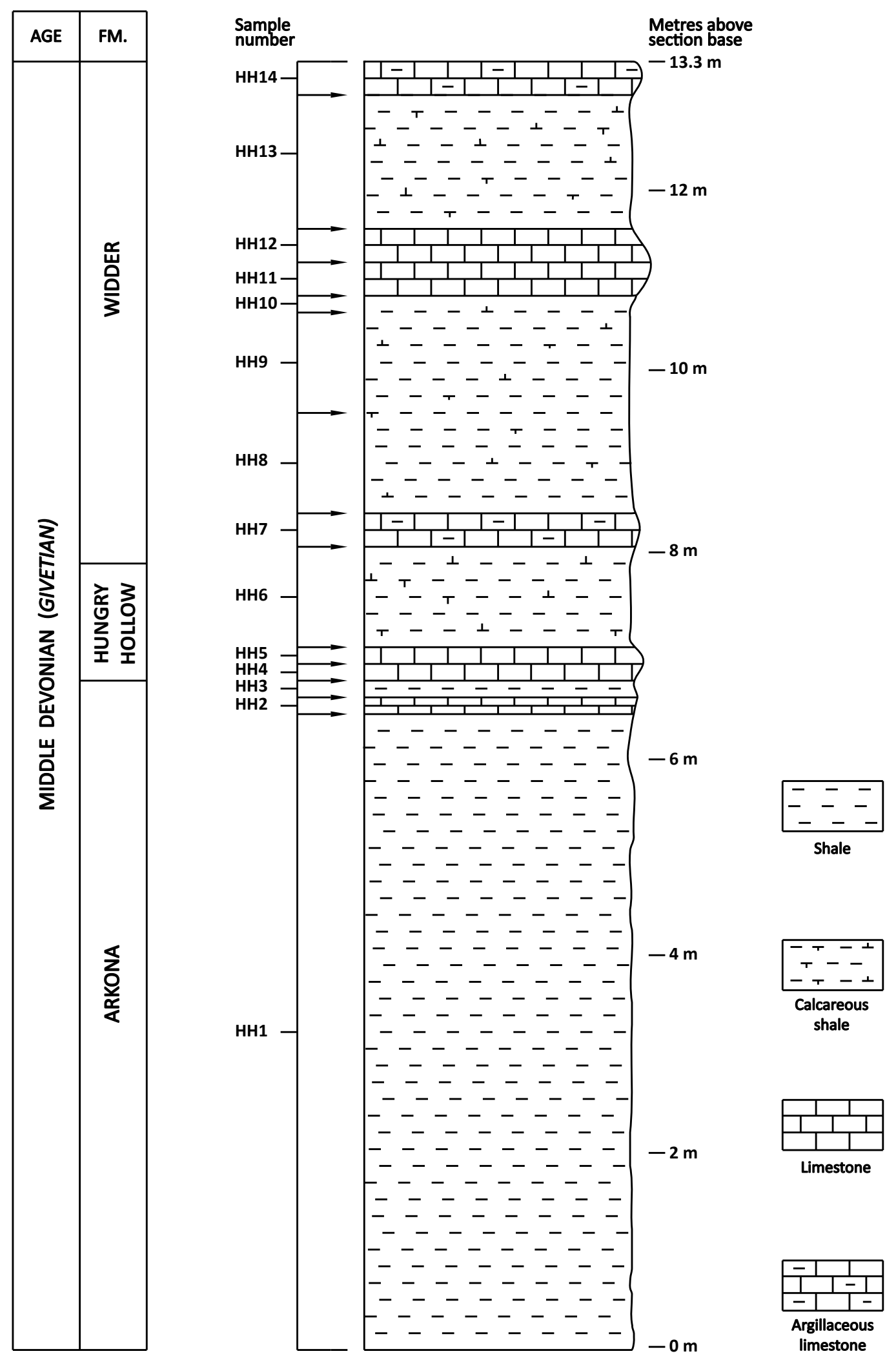

Figure 2. Stratigraphic section at the Hungry Hollow collecting site showing palynologic sampling levels in the Arkona, Hungry Hollow and Widder formations.

Figura 2. Sección estratigráfica de la zona de recogida de muestras en Hungry Hollow en la que se indican los niveles palinológicos en las formaciones Arkona, Hungry Hollow y Widder. 


\begin{tabular}{|c|c|c|c|}
\hline SERIES & STAGE & GROUP & FORMATION \\
\hline & & \multirow{6}{*}{ 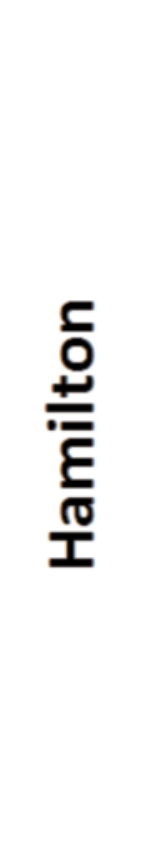 } & Ipperwash \\
\hline & & & Widder \\
\hline & & & Hungry Hollow \\
\hline \multirow{3}{*}{$\begin{array}{l}\mathbf{u} \\
\underline{\mathbf{2}} \\
\underline{\Sigma}\end{array}$} & $\frac{2}{10}$ & & Arkona \\
\hline & & & Rockport Quarry \\
\hline & & & Bell \\
\hline
\end{tabular}

Figure 3. Stratigraphy of the Middle Devonian Hamilton Group in southwestern Ontario, Canada (modified from Armstrong and Carter, p. 17, table 3). Shading indicates the three formations sampled for the present study.

Figura 3. Estratigrafía del Devónico Medio del Grupo Hamilton en el suroeste de Ontario, Canadá (modificado de Armstrong and Carter, p. 17, tabla 3). El sombreado indica las tres formaciones muestreadas para el presente estudio.

Sampling consisted of either individual spot samples (HH2-HH5), or composite samples within an interval of uniform lithology ( $\mathrm{HH} 1, \mathrm{HH} 6-\mathrm{HH} 14)$.

Approximately $50 \mathrm{~g}$ of each sample were processed using standard palynologic techniques consisting of successive treatments with cold $\mathrm{HCl}, \mathrm{HF}$ and $\mathrm{HNO}_{3}$ for the respective removal of carbonates, silicates and sulfides, with washings in distilled water for neutralization between each acid treatment. The resultant residue was treated with $3 \% \mathrm{NH}_{3} \mathrm{OH}$ to remove excess humic material.

Those residues showing significant disparities in palynomorph size were sieved through a $52 \mu \mathrm{m}$ screen and three slides of the $>52 \mu \mathrm{m}$ fraction were prepared. The remaining residue was sieved via a $20 \mu \mathrm{m}$ screen and three slides of the $20-52 \mu \mathrm{m}$ fraction and one slide of the $<20 \mu \mathrm{m}$ fraction were prepared (samples $\mathrm{HH} 1-3, \mathrm{HH} 7-10, \mathrm{HH} 12, \mathrm{HH} 13)$. The residues con- taining palynomorphs of relatively uniform size were sieved only through a $20 \mu \mathrm{m}$ screen and three slides of the $>20 \mu \mathrm{m}$ fraction and one slide of the $<20 \mu \mathrm{m}$ fraction were prepared (samples $\mathrm{HH} 4-6, \mathrm{HH} 11, \mathrm{HH} 14$ ). Petropoxy 154 was the permanent mounting medium for all slides.

For relative abundance data (Table 1), all palynomorphs from the three $>20 \mu \mathrm{m}$ fraction slides were counted. In those samples where $>52 \mu \mathrm{m}$ slides were prepared, the palynomorphs from the three $>52 \mu \mathrm{m}$ fraction slides, as well as the three 20-52 $\mu \mathrm{m}$ slides, were counted. Counts were not made from the $<20$ $\mu \mathrm{m}$ slide, but the slide was examined to confirm that there were no palynomorphs in that fraction that were not present in the larger fractions.

Strew slides $(\mathrm{HH} 1-\mathrm{HH} 14)$ of the $>52 \mu \mathrm{m}, 20-52 \mu \mathrm{m}$ and $>20 \mu \mathrm{m}$ fractions were examined with an Olympus $\mathrm{BH} 2$ binocular microscope, under brightfield illumination. With the exception of Tasmanites sp. (Plate 2, Fig. 5), which was photographed using a $40 x$ objective, all the other palynomorphs are illustrated via a $60 x$ oil-immersion objective, with an Olympus DP26 digital camera. The images were captured with Olympus cellSens ${ }^{\circledR}$ software.

\section{Repository}

The 31 strew slides from which 71 palynomorph specimens are illustrated (Plates 1-4), are housed permanently in the Geological Survey of Canada, National Invertebrate and Plant Type Fossil Collection, 601 Booth Street, Ottawa, Ontario, Canada. Curatorial details (slide numbers, England Finder ${ }^{\mathrm{TM}}$ (EF) coordinates of individual specimens on the slides and the Geological Survey of Canada type catalogue numbers) are specified in Appendix 1.

\section{Systematic palaeontology}

Forty-nine species of organic-walled microphytoplankton - 32 acritarch species, 16 prasinophyte species and one chitinozoan species - were recovered from the Hungry Hollow locality (Fig. 1). The assemblage consists of 27 named acritarch species, 14 named prasinophyte species and one named chitinozoan species. Five acritarch and two prasinophyte species are left in open nomenclature. In addition, other chitinozoans, scolecodonts (e.g. Plate 4, Fig. 4) and amorphous kerogen particles in varying proportions were also encountered, but not identified taxonomically.

Taxa considered herein to be prasinophyte phyco- 

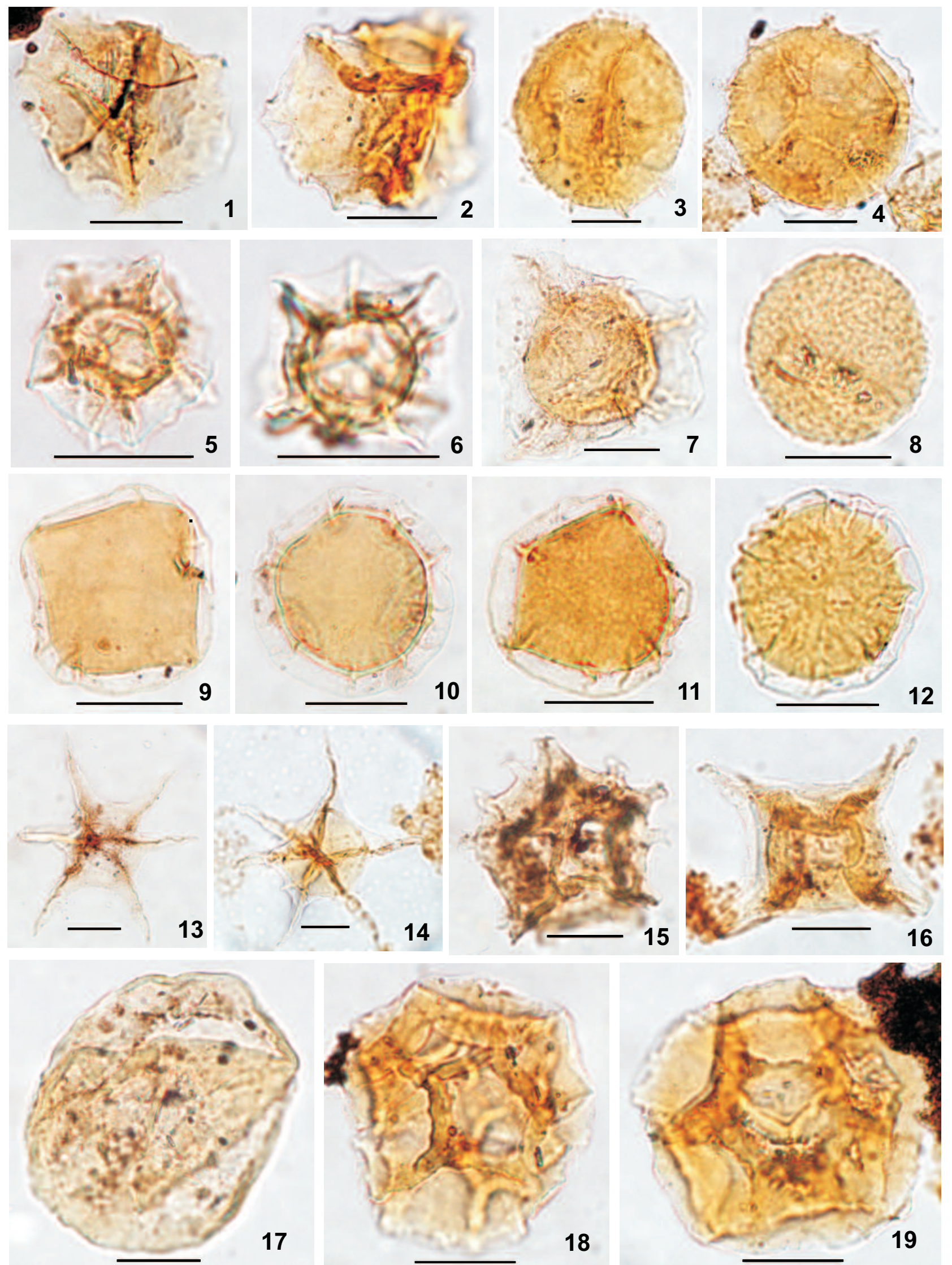
mata are placed in the Class Prasinophyceae Christensen, 1962, and arranged alphabetically by genera. The acritarchs are treated as form genera and species following the rules of the International Code of Nomenclature for algae, fungi, and plants (ICN: McNeill et al., 2012), and are also arranged alphabetically under the informal Group Acritarcha Evitt, 1963. The named chitinozoan species is placed in the chitinozoan Order Operculatifera Eisenack, 1931.

In the synonymy listings, the original binomial designation (basionym) and any subsequent generic transfers are listed, and where deemed apt, a reference to a complete synonymy is given. Remarks and comparisons (where appropriate), sample occurrence and stratigraphic and geographic distribution are also documented. Measurements of each species are not recorded because of close conformity with published size ranges thereof. For those species cited in open nomenclature, and those in which it was thought necessary for clarification, descriptions and measurements are appended.

Type-species designations are abbreviated as follows: OD, original designation; SD, subsequent designation; $\mathrm{M}$, monotypy.

\section{Prasinophyte phycomata}

Division CHLOROPHYTA Pascher, 1914

Class PRASINOPHYCEAE Christensen, 1962

Genus Arkonites Legault, 1973

Type species: Arkonites bilixus Legault, 1973 [OD; M].

Arkonites bilixus Legault, 1973

Plate 1, Figs. 1, 2

1967a Polyedryxium sp. Brito, p. 13, pl. 2, fig. 8.

1973 Arkonites bilixus Legault, pp. 52-53, pl. 11, figs. $22,23$.

1974 Acritarch sp. Anan-Yorke, p. 200, pl. 20, fig. 10. 1979 Polyedryxium sp. cf. P. talus Pöthe de Baldis, pp. 167-168, pl. 1, figs. 6, 10, pl. 2, fig. 2.

1999 Arconites bilixius (sic) Legault; Turnau and Racki, pp. 249, 268, pl. 4, fig. 19.

Occurrence. Samples HH2, HH4, HH5, HH9.

Previous records. Arkonites bilixus Legault, 1973 has been reported from the Givetian, Ontario (Legault 1973); Givetian, Ohio (Wicander and Wood 1981); Middle Devonian, Ohio and Kentucky (Wicander and Wright 1983; Huysken et al. 1992); Givetian-early Frasnian, Argentina (Barreda 1986; Ottone 1996; Rubinstein 1999, 2000; Amenábar et al. 2006); Late Devonian, Paraguay (Pöthe de Baldis 1979); ?Mississippian, Lake Titikaka, Bolivia (Vavrdová et al. 1993); Givetian, central Poland (Turnau and Racki 1999); and possibly Emsian-Frasnian, Ghana (AnanYorke 1974).

Genus Cymatiosphaera O. Wetzel, 1933 ex Deflandre, 1954

Type species: Cymatiosphaera radiata O. Wetzel, 1933 [SD; Deflandre 1954, p. 257].

Cymatiosphaera canadense Deunff, 1954 ex Deunff, 1961

Plate 1, Figs. 3, 4

1954 Cymatiosphaera canadensis Deunff, p. 1065, fig. 10 (nom. nud.).

1955 Cymatiosphaera canadensis Deunff, p. 142, fig. 10 (nom. nud.).

1961 Cymatiosphaera canadensis Deunff, p. 218.

Remarks. We doubt that Górka's (1969) Tremadoc occurrence of Cymatiosphaera canadense from Poland is correct because of poor preservation and the fact that $C$. canadense has been reported authentically only from the Devonian (see Previous records below).

Occurrence. Samples HH3, HH4, HH7-HH10, HH12, $\mathrm{HH} 13$.

Previous records. Cymatiosphaera canadense Deunff, 1954 ex Deunff, 1961 has been reported as follows: from the presumed Early or Middle Devonian of Ontario (Deunff 1954, 1955, 1956, 1961, 1966a); late Pragian-Givetian, Ontario (Legault 1973; Playford 1977); Middle Devonian, Ohio (Wicander and Wright 1983); Givetian-early Frasnian, Argentina (Rubinstein 1999, 2000; Amenábar et al. 2006); late Tremadoc and

Plate 1 (lámina 1). Prasinophyte photomicrographs. 1, 2, Arkonites bilixus Legault, 1973. 3, 4, Cymatiosphaera canadense Deunff, 1954 ex Deunff, 1961. 5, 6, Cymatiosphaera cornifera Deunff, 1955. 7, Cymatiosphaera winderi Deunff, 1967. 8, Dictyotidium variatum Playford, 1977. 9, Duvernaysphaera angelae Deunff, 1964. 10-12, Duvernaysphaera tenuicingulata Staplin, 1961. 13, 14, Polyedryxium ambitum Wicander and Wood, 1981. 15, Polyedryxium decorum Deunff, 1955. 16, Polyedryxium embudum Cramer, 1964. 17, Leiosphaeridia sp. 18, 19, Muraticavea munifica Wicander and Wood, 1981. Scale bars $=20 \mu \mathrm{m}$. 
Wicander, R. and Playford, G., 2017. Organic-walled microphytoplankton assemblage... Boletín Geológico y Minero, 128 (4): $839-883$

late Famennian, Poland (Górka 1969, 1974); and Givetian, western Libya (Moreau-Benoit 1984).

\section{Cymatiosphaera cornifera Deunff, 1955 Plate 1, Figs. 5, 6}

1955 Cymatiosphaera cornifera Deunff, p. 147, fig. 23.

Remarks. Notwithstanding Deunff's (1955) provision of only a single line-drawing, this species is easily recognized by its delicate high muri and the relatively large meshes of its reticulum (Playford 1977, p. 17, pl. 4, figs. 4-14).

Occurrence. Samples HH1, $\mathrm{HH} 4, \mathrm{HH} 12$.

Previous records. Cymatiosphaera cornifera Deunff, 1955 has been recorded from the Middle Devonian-Frasnian, Ontario (Deunff 1955, 1966a, 1967); late Pragian-middle Givetian, Ontario (Playford 1977); Givetian, Ohio (Wicander and Wood 1981); Middle Devonian, Ohio (Wicander and Wright 1983); Pragian, northern Bolivia (Vavrdová et al. 1996); late Givetian-early Frasnian, Boulonnais, France (Deunff 1981); Eifelian, China (Zhu Huaicheng et al. 2008); and Tournaisian/Tn1b, Xizang/Tibet (Gao Lianda 1986). Stockmans and Willière (1969) figured a putative example of $C$. cornifera from the early Famennian of Belgium, but a positive attribution is considered questionable (Playford 1977).

\section{Cymatiosphaera winderi Deunff, 1967 Plate 1, Fig. 7}

1967 Cymatiosphaera winderi Deunff, pp. 259-260, figs. 13, 17.

1967 Cymatiosphaera sp. cf. C. winderi Deunff; Deunff, p. 259, fig. 15.

Occurrence. Samples HH1, HH2, HH4, HH6-HH9, $\mathrm{HH} 12, \mathrm{HH} 13$.

Previous records. Cymatiosphaera winderi Deunff, 1967 occurs in the Frasnian, Ontario (Deunff 1967); Emsian-middle Eifelian and early-middle Givetian, Ontario (Playford 1977); Givetian, Ohio and Kentucky (Wicander and Wood 1981; Wood and Clendening 1985); late Givetian, lowa (Wicander and Wood 1997); and Givetian, western Libya (Moreau-Benoit 1984).

Genus Dictyotidium Eisenack, 1955 emend. Staplin, 1961
Type species: Dictyotidium dictyotum (Eisenack, 1938) Eisenack, 1955 [OD].

\section{Dictyotidium variatum Playford, 1977}

Plate 1, Fig. 8

1973 Dictyotidium dictyotum Legault, p. 52 (pars), pl. 11, fig. 10 (only).

1977 Dictyotidium variatum Playford, pp. 18-19, pl. 5, figs. 2-4, pl. 6, figs. 1-6.

1983 Dictyotidium sp. cf. D. variatum Playford; Wicander and Wright, p. 5, fig. 3 (5).

Occurrence. Samples HH2, HH4.

Previous records. Prior reports of Dictyotidium variatum Playford, 1977 are as follows: Givetian, Ontario (Legault 1973); late Pragian-middle Givetian, Ontario (Playford 1977); Lochkovian, Oklahoma (Wicander 1986); Givetian, Ohio and Kentucky (Wicander and Wood 1981; Wood and Clendening 1985); late Givetian, lowa (Wicander and Wood 1997); Middle Devonian, Ohio (Wicander and Wright 1983); and Tournaisian/Tn1b, Xizang/Tibet (Gao Lianda 1986).

\section{Genus Duvernaysphaera Staplin, 1961, emend. Deunff, 1964}

Type species: Duvernaysphaera tenuicingulata Staplin, 1961 [OD].

Duvernaysphaera angelae Deunff, 1964 Plate 1, Fig. 9

1964 Duvernaysphaera angelae Deunff, pp. 211-212, fig. 1.

1964 Duvernaysphaera tessella Deunff, p. 212, fig. 5. 1966 Veliferites tenuimarginatus Brito, p. 79 (nom. nud.).

1967b Veliferites tenuimarginatus Brito, p. 477, pl. 1, figs. 4-8.

1981 Duvernaysphaera tessella Deunff; Playford and Dring, pp. 26-28, pl. 6, figs. 4-9.

1986 Duvernaysphaera tessella Deunff; Barreda, p. 231, pl. 1, figs. 1, 2.

For further synonymy up to 1981 , see Wicander and Wood (1981, p. 23).

Description. Vesicle typically quadrangular ( \pm square) in outline, each side 26-32 $\mu \mathrm{m}$ long; margins straight to slightly convex or slightly concave; eilyma $\sim 1 \mu \mathrm{m}$ thick, psilate to faintly scabrate; thin, diaphanous, psilate membrane (equatorial flange), 2.4-4.8 $\mu \mathrm{m}$ wide, 
surrounding vesicle; membrane supported by 1-4, narrow, solid, rod-like planar extensions (1.6-4 $\mu \mathrm{m}$ long) at or near vesicle corners; flange, where complete, presenting an overall subcircular outline, 34-40 $\mu \mathrm{m}$ in diameter. No excystment structure observed.

Remarks and comparison. The holotype description of Duvernaysphaera Deunff, 1964 does not mention the vesicle wall surface, and although its line-drawing suggests superficial punctation or scabration, we interpret his illustrations as artistic license because all of the other described species show the same type of surface character for both the vesicle and the equatorial membrane. This artistic rendition likewise applies to Duvernaysphaera tessella Deunff, 1964, despite Deunff's description specifying a granulate vesicle.

Our specimens have a psilate to faintly scabrate eilyma and the same vesicle diameter as, but slightly smaller overall diameter than, D. tessella of Playford (in Playford and Dring 1981). The latter author considered Veliferites tenuimarginatus Brito, 1967 to be a junior synonym of $D$. tessella; this is endorsed herein.

Occurrence. Samples HH1-HH10, $\mathrm{HH} 12, \mathrm{HH} 13$.

Previous records. The extensive palaeogeographic and (mainly Middle-Late) Devonian distribution of Duvernaysphaera angelae Deunff, 1964 is evident from prior publications, as follows: Givetian, Ohio and Kentucky (Wicander and Wood 1981; Wood and Clendening 1985); Middle Devonian, Ohio (Wicander and Wright 1983); Middle and Late Devonian, Kentucky (Huysken et al. 1992); Early Devonian (= Zone R), Maranhão Basin, Brazil (Brito 1966, 1967a, b, c); Middle Devonian, northwest Paraguay (Pöthe de Baldis 1974); Givetian-early Frasnian, Argentina (Barreda 1986; Ottone 1996; Amenábar et al. 2006); late Famennian, southeast Bolivia (Wicander et al. 2011); Late Devonian-Mississippian, Bolivia (Vavrdová et al. 1993, 1996); early Frasnian, Boulonnais, France (Deunff 1981); late Famennian, Portugal (Pereira et al. 2008); undifferentiated Devonian, Tunisia (Deunff 1964, 1966b); Eifelian-Famennian, Algerian Sahara (Jardiné and Yapaudjian 1968; Lanzoni and Magloire 1969; Jardiné 1972; Jardiné et al. 1974); Emsian-Frasnian, Ghana (Anan-Yorke 1974); and Frasnian, Western Australia (Playford and Dring 1981).

Duvernaysphaera tenuicingulata Staplin, 1961 Plate 1, Figs. 10-12

1961 Duvernaysphaera tenuicingulata Staplin, pp. 415-416, pl. 49, figs. 10, 11.
Description. Vesicle circular to rounded polygonal in outline, 29-37 $\mu \mathrm{m}$ in diameter; eilyma 1.8-2.1 $\mu \mathrm{m}$ thick, psilate to slightly scabrate; vesicle surrounded equatorially by thin, diaphanous, psilate membrane (equatorial flange), 3.2-4.8 $\mu \mathrm{m}$ wide, exhibiting an overall circular outline, 35-45 $\mu \mathrm{m}$ in diameter; equatorial flange braced by 9-13 narrow, irregularly spaced, solid, spine-like planar extensions, extending $4.8-8 \mu \mathrm{m}$ radially. No method of excystment observed.

Remarks. Although showing some morphological variation, the present specimens conform to the description and measurements cited in numerous publications (see below).

\section{Occurrence. Samples HH1-HH14.}

Previous records. Duvernaysphaera tenuicingulata Staplin, 1961 occurs in the late Emsian, late Eifelian and early-middle Givetian, Ontario (Playford 1977); Late Devonian, Alberta (Staplin 1961); Givetian, Ohio and Kentucky (Wicander and Wood 1981; Wood and Clendening 1985); late Givetian, lowa (Wicander and Wood 1997); Middle Devonian, Ohio (Wicander and Wright 1983); late Givetian-early Frasnian, Argentina (Barreda 1986; Ottone 1996); early Frasnian, Boulonnais, France (Deunff 1981); undifferentiated Devonian, Tunisia (Deunff 1964, 1966b); late Famennian, Portugal (Pereira et al. 2008); Givetian-Famennian, Algerian Sahara (Jardiné et al. 1974); and Frasnian, Western Australia (Playford and Dring 1981).

\section{Genus Leiosphaeridia Eisenack, 1958}

Type species: Leiosphaeridia baltica Eisenack, 1958 [OD].

\section{Leiosphaeridia sp.} Plate 1, Fig. 17

Remarks. Numerous specimens of Leiosphaeridia Eisenack, 1958 occur in all 14 samples. However, because of their simple, psilate, spherical morphology, we are leaving them in open nomenclature and simply noting their presence as part of the palynoflora.

Occurrence. Samples HH1-HH14.

Previous records. Leiosphaeridia spp. are widely dispersed, with a stratigraphic range of Proterozoic to Recent. 
Wicander, R. and Playford, G., 2017. Organic-walled microphytoplankton assemblage... Boletín Geológico y Minero, 128 (4): $839-883$

Genus Muraticavea Wicander, 1974

Type species: Muraticavea enteichia Wicander, 1974 [OD; M].

Muraticavea munifica Wicander and Wood, 1981 Plate 1, Figs. 18, 19

1981 Muraticavea munificus Wicander and Wood, pp. 24-25, pl. 2, figs. 6-9.

Occurrence. Samples HH1-HH9, HH11-HH13.

Previous records. This species has been reported from the Givetian, Ohio (Wicander and Wood 1981); late Givetian, lowa (Wicander and Wood 1997); Middle Devonian, Ohio (Wicander and Wright 1983); Givetian-early Frasnian, Argentina (Barreda 1986; Ottone 1996; Rubinstein 1999, 2000, Amenábar et al. 2006); and late Famennian, southeast Bolivia (Wicander et al. 2011).

\section{Genus Polyedryxium Deunff, 1954 ex Deunff, 1961}

Type species: Polyedryxium deflandrei Deunff, 1954 [SD; Deunff 1961, p. 216].

Polyedryxium ambitum Wicander and Wood, 1981 Plate 1, Figs. 13, 14

1981 Polyedryxium ambitum Wicander and Wood, p. 26 , pl. 3, figs. 1,2 .

1983 Polyedryxium sp. cf. P. ambitum Wicander and Wood; Wicander and Wright, p. 10, fig. 3 (9).

Occurrence. Samples HH2, HH6-HH9, HH13.

Previous records. Polyedryxium ambitum Wicander and Wood, 1981 has been recorded from the Givetian, Ohio (Wicander and Wood 1981); Middle Devonian, Ohio (Wicander and Wright 1983, cf. designation only); and late Givetian-early Frasnian, Argentina (Barreda 1986; Ottone 1996).

\section{Polyedryxium decorum Deunff, 1955 Plate 1, Fig. 15}

1955 Polyedryxium decorum Deunff, pp. 146-147, pl. 2, fig. 1.

1967 Polyedryxium sp. cf. P. decorum Deunff; Deunff, p. 259 , fig. 6 .

For further synonymy, see Wicander and Wood (1981, p. 27).
Occurrence. Sample HH1.

Previous records. Polyedryxium decorum Deunff, 1955 occurs in the Middle Devonian, Ontario (Deunff 1955, 1966a, 1971); Late Devonian, Saskatchewan and Ontario (Deunff 1967; Nautiyal 1977); late Emsian, early-middle Eifelian and early-middle Givetian, Ontario (Playford 1977); Givetian, Ohio and Kentucky (Wicander and Wood 1981; Wood and Clendening 1985); late Givetian, lowa (Wicander and Wood 1997); late Frasnian, lowa (Wicander and Playford 1985); Givetian-early Frasnian, Argentina (Rubinstein 1999, 2000; Amenábar et al. 2006); Ludlovian-Emsian (in part), northwest Spain (Cramer 1963, 1964); Givetian, western Libya (Moreau-Benoit 1984; Massa and Moreau-Benoit 1985); and late Emsian-Famennian, Algerian Sahara (Jardiné 1972; Jardiné et al. 1974).

\section{Polyedryxium embudum Cramer, 1964 Plate 1, Fig. 16; Plate 2, Fig. 1}

1964 Polyedryxium embudum Cramer, pp. 318-319, fig. 32 (5).

1966a Polyedryxium nudatum Deunff, pp. 91-92, pl. 13, fig. 150.

1981 Polyedryxium sp. cf. P. embudum Cramer; Wicander and Wood, p. 27, pl. 3, fig. 5.

1983 Polyedryxium embudum? Cramer; Wicander and Wright, p. 10, fig. 3 (12).

1984 Polyedryxium sp. cf. P. embudum Cramer; Molyneux, Manger and Owens, p. 47, pl. 2, figs. 9, 10. 1985 Polyedryxium sp. cf. P. embudum Cramer; Wicander and Playford, p. 114, pl. 5, figs. 4, 7. 1990 Polyedryxium sp. cf. P. embudum Cramer; Colbath, p. 198, pl. 3, figs. 7, 21, 22, text-fig. 7.

Remarks. Playford (1977, p. 34) noted that when Deunff (1971) included both Polyedryxium nudatum and Cramer's (1964) P. embudum in his treatise on Polyedryxium and related species, he did not attempt any differential distinction between them. In fact, neither species was given anything other than a cursory description, nor was either adequately illustrated. Hence, we consider $P$. nudatum and $P$. embudum as conspecific.

Occurrence. Samples HH2, HH7-HH11, HH13.

Previous records. With an inclusive stratigraphic range of Pragian-Famennian, Polyedryxium embudum Cramer, 1964 has been variously reported as follows: Early and Middle Devonian, Ontario (Deunff 1966a, 1971); Emsian and early Eifelian, Ontario 
(Playford 1977); Late Devonian, Alberta (Nautiyal 1977); Givetian, Ohio (Wicander and Wood 1981); Middle Devonian, Ohio (Wicander and Wright 1983); late Frasnian, lowa (Wicander and Playford 1985); late Famennian, Ohio (Molyneux et al. 1984) and Illinois (Wicander and Playford 2013); Givetian-early Frasnian, Argentina (Barreda 1986; Ottone 1996; Amenábar 2009); middle Pragian-Emsian (in part), northwest Spain (Cramer 1964); undifferentiated Devonian, Tunisia (Deunff 1971); Frasnian-Famennian, northern Iran (Ghavidel-syooki 1994); Eifelian, China (Zhu Huaicheng et al. 2008); late Frasnian-Famennian, Xinjiang, China (Lu Li-chang and Wicander 1988); Givetian-Frasnian, Western Australia (Colbath 1990); and Frasnian, Western Australia (Playford and Dring 1981).

Polyedryxium fragosulum Playford, 1977 Plate 2, Figs. 2, 3

1977 Polyedryxium fragosulum Playford, pp. 34-35, pl. 16, figs. 8-14.

1986 Eisenackidium duplex auct. non Cramer; Barreda, p. 231, pl. 2, fig. 10.

Occurrence. Samples HH1, HH2, HH4, HH7-HH9, $\mathrm{HH} 13$.

Previous records. Polyedryxium fragosulum Playford, 1977 is known from the late Pragian-middle Emsian, Ontario (Playford 1977); Givetian, Ohio and Kentucky (Wicander and Wood 1981; Wood and Clendening 1985); Middle Devonian, Ohio (Wicander and Wright 1983); late Givetian-early Frasnian, Argentina (Ottone 1996); and undifferentiated Devonian, Tunisia (Deunff 1966b).

\section{Polyedryxium pharaone Deunff, 1961} Plate 2, Figs. 6, 7

1954 Polyedryxium pharaonis Deunff, p. 1065, fig. 13 (nom. nud.).

1955 Polyedryxium pharaonis Deunff, p. 143, fig. 13 (nom. nud.).

1961 Polyedryxium pharaonis Deunff, p. 217.

1966a Polyedryxium pharaonis (Deunff, 1961); Deunff, pp. 58-62, pl. 7, figs. $79,80,82-85$, pl. 8, figs. 92-94, pl. 12, fig. 126, pl. II, fig. 12, pl. VI, figs. 42, 43.

1972 Crameria pharaonis (Deunff, 1961) Jardiné, Combaz, Magloire, Peniguel and Vachey, pp. 301-302, pl. 2, figs. 6-10. (?non Crameria pharaonis (Deunff) subsp. duplex (Cramer) Jardiné, Combaz, Magloire, Peniguel and Vachey, 1972, p. 301).
For further synonymy, see Wicander and Wood (1981, pp. 28-29), Wicander (1983, p. 71) and Lu Lichang and Wicander (1988, p. 127).

\section{Occurrence. Samples HH1-HH14.}

Previous records. Polyedryxium pharaone Deunff, 1961 is widely distributed in North America, South America, North Africa, the Middle East, Europe, Australia and China, with a stratigraphic range of Pragian-Famennian (Wicander and Playford 2013). For citations of preceding occurrences and their stratigraphic ranges therein, see Playford and McGregor (1993) and Hashemi and Playford (1998).

\section{Genus Staplinium Jansonius, 1962}

Type species: Staplinium hexaeder Jansonius, 1962 [OD; M].

\section{Staplinium cuboides (Deunff, 1955) Deunff, 1971} Plate 2, Fig. 4

1955 "Polyedryxium" cuboides Deunff, p. 147, fig. 19. 1967 Polyedryxium sp. aff. P. cuboides Deunff; Deunff, p. 258, fig. 18.

1971 Staplinium cuboides (Deunff, 1955); Deunff, p. 42, pl. 1, figs. 11, 12, 17, pl. 8, fig. 16.

1980 Cymatiosphaera cubus Deunff, p. 493, table 1.

Remarks and comparison. Deunff (1961, p. 216; 1971, p. 42) implied that Polyedryxium cuboides Deunff, 1955 might be synonymous with Staplinium hexaeder Jansonius, 1962 (= type species of Staplinium). However, S. hexaeder is Early Triassic in age, whereas all occurrences of Staplinium cuboides (Deunff, 1955) Deunff, 1971 are Devonian.

This species is similar to Polyedryxium embudum Cramer, 1964 but lacks the irregularly crenate boundaries or crests present in Cramer's species. This distinction is not always clearly evident, and the two species cannot be differentiated unequivocally, especially if the specimens are not well preserved. Hence, indifferently preserved specimens are sometimes attributed to $S$. cuboides, rather than to P. embudum.

Occurrence. Samples HH1, HH2, HH4-HH9, HH12, $\mathrm{HH} 13$.

Previous records. Staplinium cuboides (Deunff, 1955) Deunff, 1971 has been reported from the Middle Devonian, Ontario (Deunff 1955, 1956, 1971); Givetian, Ontario (Legault 1973); Lochkovian, Frasnian, France 

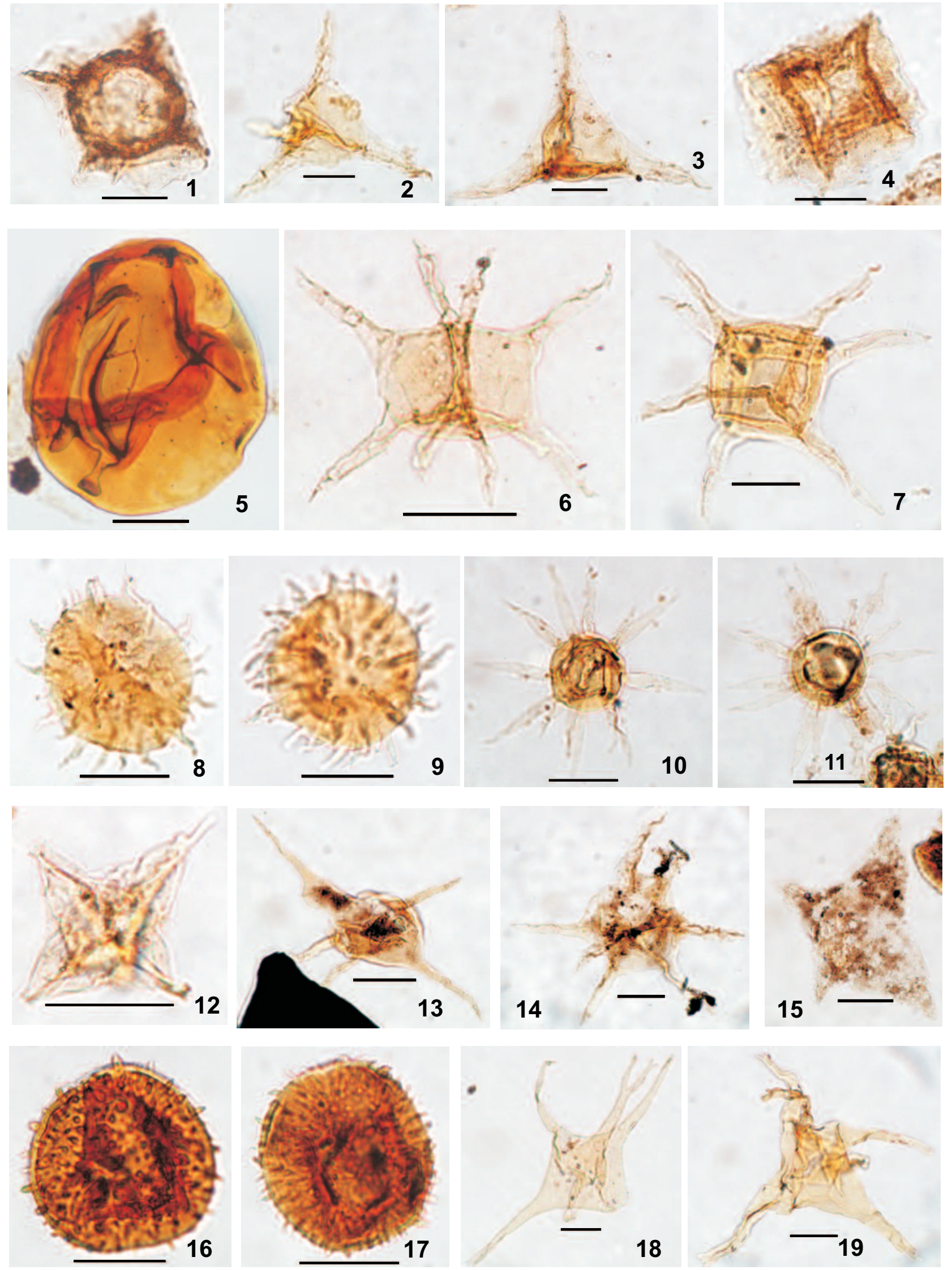
(Deunff 1980, 1981); and Pragian-Emsian (in part), northwest Spain (Cramer 1963).

Genus Tasmanites Newton, 1875

Type species: Tasmanites punctata Newton, 1875 [OD].

Tasmanites sp.

Plate 2, Fig. 5

Remarks. Specimens of Tasmanites Newton, 1875 are present throughout the sampled section. However, because of their simple, thick-walled, punctate, spherical morphology, we are leaving the cohort in open nomenclature and simply noting their occurrence as part of the palynologic assemblage.

Occurrence. Samples HH1-HH14.

Previous records. Tasmanites spp. are globally distributed, ranging from Proterozoic to Recent.

\section{Acritarcha}

Group ACRITARCHA Evitt, 1963

Genus Ammonidium Lister, 1970

Type species: Ammonidium microcladum (Downie, 1963) Lister, 1970 [OD].

\section{Ammonidium sp. A \\ Plate 2, Figs. 8, 9}

Description. Vesicle originally spherical, circular to subcircular in outline, distinct from processes; 34-38 $\mu \mathrm{m}$ in diameter; eilyma $0.6-1.6 \mu \mathrm{m}$ thick, surface psilate; numerous (24-31) hollow, homomorphic (predominantly) to heteromorphic psilate processes, 6-10 $\mu \mathrm{m}$ long, \pm evenly distributed over eilyma; typically straight to curved proximal contacts $(1.6-3.2 \mu \mathrm{m}$ in diameter); processes slightly taper to typically spinelike bifurcant or less commonly acuminate distal tip; bifurcant spine-like projections seemingly solid, subequal, $0.5-1 \mu \mathrm{m}$ long; process interiors appear uncommunicative with vesicle interior. No method of excystment observed.

Comparison and remarks. This species differs from Ammonidium inornatum Colbath, 1990 (GivetianFrasnian, Western Australia) in having a larger vesicle and more numerous and longer processes, which are either distally acuminate or bifurcant. It differs from A. garrasinoi Ottone, 1996 (late Givetian-early Frasnian, Argentina) in possessing a psilate eilyma and numerous, shorter processes that are either acuminate or bifurcant distally. Lastly, the present form differs from $A$. hamatum Wicander, 1974 (Late Devonian, Ohio) in its larger vesicle, somewhat longer and distally bifurcatant or acuminate processes.

Although distinct from other named species of Ammonidium, a lack of sufficient, well-preserved specimens necessitates leaving this form in open nomenclature.

Occurrence. Samples HH1-HH10, HH12, HH13.

Genus Baltisphaeridium Eisenack, 1958 ex Eisenack, 1959 emend. Eisenack, 1969

Type species: Baltisphaeridium longispinosum (Eisenack, 1931) Eisenack, 1958 [OD].

Baltisphaeridium distentum Playford, 1977 Plate 2, Figs. 10, 11

1977 Baltisphaeridium distentum Playford, pp. 12-13, pl. 1, figs. 13,14 , pl. 2, figs. 1-5, text-fig. 4.

1993 Baltisphaerosum sp. A Playford and McGregor, pp. 12-13, pl. 3, figs. 3,4 .

1996 Baltisphaerosum distentum (Playford, 1977) Ottone, pp. 121-122, pl. 4, fig. 8.

For further synonymy, see Ottone (1996, p. 121).

Remarks. Baltisphaeridium distentum Playford, 1977 is a distinctive species with basally constricted processes having well-developed basal plugs preventing free communication with the vesicle interior. Furthermore, the processes are thin-walled in contrast to the thicker-walled eilyma.

Plate 2 (lámina 2). Prasinophyte (1-7) and acritarch (8-19) photomicrographs. 1, Polyedryxium embudum Cramer, 1964. 2, 3, Polyedryxium fragosulum Playford, 1977. 4, Staplinium cuboides (Deunff, 1955). 5, Tasmanites sp. 6, 7, Polyedryxium pharaone Deunff, 1961. 8, 9, Ammonidium sp. A. 10, 11, Baltisphaeridium distentum Playford, 1977. 12, Daillydium pentaster (Staplin, 1961) emend. Playford in Playford and Dring, 1981. 13, Diexallophasis simplex Wicander and Wood, 1981. 14, Eisenackidium appendiculum Wicander and Wood, 1981. 15, Estiastra rhytidoa Wicander and Wood, 1981. 16, 17, Gorgonisphaeridium inflatum Wicander and Wood, 1981. 18, 19, Exochoderma arca Wicander and Wood, 1981. Scale bars $=20 \mu \mathrm{m}$. 
Wicander, R. and Playford, G., 2017. Organic-walled microphytoplankton assemblage... Boletín Geológico y Minero, 128 (4): $839-883$

Occurrence. Samples HH1-HH13.

Previous records. Baltisphaeridium distentum Playford, 1977 is known from the Pragian-Famennian of North America (Playford 1977; Wicander and Wood 1981; Wicander and Wright 1983; Wood and Clendening 1985; Wood 1986; Playford and McGregor 1993; Wicander and Playford 2013); late Givetian-early Frasnian, Argentina (Barreda 1986; Ottone 1996); and late Famennian, southeast Bolivia (Wicander et al. 2011).

\section{Genus Daillydium Stockmans and Willière, 1969}

Type species: Daillydium pentaster (Staplin, 1961)

Playford in Playford and Dring, 1981 [OD as

Daillydium quadridactylites (Stockmans and Willière, 1962a) Stockmans and Willière, 1969 = junior synonym of $D$. pentaster].

\section{Daillydium pentaster (Staplin, 1961) emend. Playford, 1981 \\ Plate 2, Fig. 12}

1961 Cymatiosphaera pentaster Staplin, p. 416, pl. 49, fig. 18.

1961 Cymatiosphaera tetraster Staplin, p. 416, pl. 49, fig. 15.

1962a Hystrichosphaeridium quadridactylites Stockmans and Willière, pp. 67-68, pl. 1, fig. 18, textfig. 29.

non 1962b Cymatiosphaera pentaster Staplin; Stockmans and Willière, p. 97, pl. 1, fig. 15, text-fig. 16. 1969 Daillydium quadridactylites (Stockmans and Willière, 1962a) Stockmans and Willière, pp. 33-35, pl. 1, figs. 1-14.

1976 Cymatiosphaera sp. 3 Nautiyal, p. 299, fig. 1 (4). 1976 Cymatiosphaera sp. 6 Nautiyal, p. 299, fig. 1 (5). 1976 Cymatiosphaera sp. 4 Nautiyal, p. 299, fig. 1 (6). 1977 Cymatiosphaera pentaster Staplin; Nautiyal, pp. 56-57, pl. 1, figs. 2, 3.

1977 Cymatiosphaera sp. 3 Nautiyal, pp. 56-57, pl. 1, figs. 4,5 .

1977 Cymatioshpaera sp. 4 Nautiyal, pp. 56-57, pl. 1, figs. 6,7 .

1981 Daillydium pentaster (Staplin, 1961) Playford, in Playford and Dring, pp.17-18, pl. 3, figs. 1-14, text fig. 4.

For further synonymy, see Colbath (1990, p. 114.)

Remarks. Playford in Playford and Dring (1981) discussed the morphological variability of Daillydium pentaster (Staplin, 1961) Playford, 1981 and provided an overview of the taxonomy of this species as it rela- tes to Cymatiosphaera pentaster Staplin, 1961, C. tetraster Staplin, 1961 and Daillydium quadridactylites (Stockmans and Willière, 1962a) Stockmans and Willière, 1969.

Occurrence. Samples HH1, HH2, HH4, HH6-HH8, $\mathrm{HH} 10-\mathrm{HH} 13$.

Previous records. Although Daillydium pentaster (Staplin, 1961) Playford, 1981 is characteristic of the Late Devonian, it has also been recorded from the Middle Devonian. Its occurrence and stratigraphic range are as follows: Late Devonian, western Canada (Staplin 1961; Nautiyal 1976, 1977); late Famennian-?early Tournaisian, southern Saskatchewan (Playford and McGregor 1993); Givetian-?Frasnian, Tennessee (Reaugh 1978, listed without illustration); late Givetian and late Frasnian, lowa (Wicander and Playford 1985; Wicander and Wood 1997); Givetian-Frasnian boundary, Argentina (Barreda 1986); Late Devonian, Paraguay (Pöthe de Baldis 1979); late Famennian, southeast Bolivia (Wicander et al. 2011); Givetian, central Poland (Turnau and Racki 1999); late Givetian-middle Frasnian, France (Deunff 1981; Le Hérissé and Deunff 1988); Frasnian-Famennian, Franco-Belgian Ardennes (Stockmans and Willière 1962a, 1969, 1974; Bain and Doubinger 1965; Martin 1981, 1985); late Frasnian-early Famennian, Brabant Massif, Belgium (Kimpe et al. 1978); Famennian, Portugal (Cunha and Oliveira 1989; Pereira et al. 1994; Pereira et al. 2008); late Famennian, Poland (Górka 1974); Frasnian, eastcentral Iran (Hashemi and Playford 1998); undifferentiated Devonian, Tunisia (Deunff 1966b); Givetian-Famennian, Algerian Sahara (Jardiné 1972; Jardiné et al. 1974); late Frasnian-Famennian, Xinjiang, China (Lu Li-chang and Wicander 1988); Givetian-Frasnian, Western Australia (Colbath 1990); and Frasnian, Western Australia (Playford 1981; Playford and Dring 1981).

\section{Genus Diexallophasis Loeblich, 1970}

Type species: Diexallophasis denticulata (Stockmans and Willière, 1963) Loeblich, 1970 [OD].

Remarks. Le Hérissé (1989, p. 125) considered both Diexallophasis Loeblich, 1970 and Exochoderma Wicander, 1974 as junior synonyms of Evittia Brito, 1967 emend. Lister, 1970. However, we do not accept that these genera constitute the morpho-continuum synthesized by Le Hérissé (1989), viz., from an inflated vesicle bearing short processes without consistent 
vesicle-process differentiation (cf. Evittia), to a distinct vesicle clearly segregated from long processes having well-defined acuminate to multi-furcate distal tips (as in Diexallophasis and Exochoderma).

We are cognizant that it is sometimes difficult to assign generically, some species that appear intermediate between these morphotype categories. Nevertheless, we consider it practicable to consign those species bearing processes that are clearly separated from the vesicle, to either Diexallophasis or Exochoderma.

\section{Diexallophasis simplex Wicander and Wood, 1981 Plate 2, Fig. 13}

1977 Diexallophasis remota (Deunff, 1955) Playford, pp. 19-20 (pars), pl. 7, figs. 2, 6, 8 (only).

1981 Diexallophasis simplex Wicander and Wood, pp. 33-34, pl. 5, fig. 7, pl. 6, figs. 1-3.

2008 Diexallophasis remota (Deunff, 1955) Playford; Zhu Huaicheng, Wicander and Marshall, p. 148, pl. 4, fig. 3.

Comparison and remarks. Diexallophasis simplex Wicander and Wood, 1981 superficially resembles several of the specimens illustrated by Playford (1977). However, as noted by Wicander and Wood (1981), there is a wide variety in eilyma sculpture, process width, and types of distal furcations, such that they did not consider all of Playford's illustrated specimens to represent a single species.

Furthermore, D. simplex closely resembles Hystrichosphaeridium spiciferum Deunff, 1955, but no description of the latter's eilyma surface was given, nor were the described grana putatively present on the processes evident in Deunff's figured specimen.

Our specimens clearly fit the circumscription of $D$. simplex, and are therefore assigned to that species rather than to D. remota (Deunff, 1955) Playford, 1977.

Occurrence. Samples HH1, HH6, HH13.

Previous records. Diexallophasis simplex Wicander and Wood, 1981 has been reported from the Givetian, Ohio (Wicander and Wood, 1981). The stratigraphic range of $D$. remota given in Playford (1977) for Ontario is Pragian-Givetian. D. remota has also been reported from the Eifelian, China (Zhu Huaicheng et al. 2008).

Genus Eisenackidium Cramer and Diez, 1968, ex Eisenack, Cramer and Diez, 1973
Type species: Eisenackidium triplodermum (Cramer, 1967) Eisenack, Cramer and Diez, 1973 [OD].

Eisenackidium appendiculum Wicander and Wood, 1981

Plate 2, Fig. 14

1981 Eisenackidium appendiculum Wicander and Wood, pp. 35-36, pl. 6, fig. 4, pl. 7, figs. 1, 2.

Occurrence. Samples HH1-4, HH6, HH9, HH12, HH13.

Previous records. This species has been reported from the Givetian, Ohio (Wicander and Wood 1981) and late Famennian-?Tournaisian, Saskatchewan (Playford and McGregor 1993).

\section{Genus Estiastra Eisenack, 1959}

Type species: Estiastra magna Eisenack, 1959 [OD]. Estiastra rhytidoa Wicander and Wood, 1981 Plate 2, Fig. 15

1973 Veryhachium sp. 1 Legault, p. 54, pl. 12, figs. 1, 2, 15, 18.

1981 Estiastra rhytidoaWicander and Wood, pp. 37-38, pl. 7, figs. 5, 6, pl. 8, figs. 1, 2 .

1999 Estiastra sp. cf. E. rhytidoa Wicander and Wood; Rubinstein, p. 16, fig. 3. D.

Occurrence. Samples HH1, HH9, HH13.

Previous records. Estiastra rhytidoa Wicander and Wood, 1981 occurs in the Givetian, Ontario (Legault 1973); Givetian, Ohio and Kentucky (Wicander and Wood 1981; Wood and Clendening 1985); Middle Devonian, Ohio (Wicander and Wright 1983); Eifelian-early Frasnian, Argentina (Barreda 1986; Rubinstein 1999, 2000; Amenábar et al. 2006).

\section{Genus Exochoderma Wicander, 1974}

Type species: Exochoderma irregularis Wicander, 1974 [OD].

Remarks. Our rationale for distinguishing between Evittia (Brito, 1967) emend. Lister, 1970 and Diexallophasis Loeblich, 1970 and Exochoderma Wicander, 1974 is discussed above, under Diexallophasis. Although Diexallophasis and Exochoderma are morphologically similar, and in our opinion, distinct from Evittia (notwithstanding Le 
Wicander, R. and Playford, G., 2017. Organic-walled microphytoplankton assemblage... Boletín Geológico y Minero, 128 (4): $839-883$

Hérissé's (1989) arguments of a morphologic continuum), we consider Exochoderma to be differentiable from Diexallophasis in having a triangular to quadrate vesicle, that commonly bears broader processes than the latter genus.

\section{Exochoderma arca Wicander and Wood, 1981 Plate 2, Figs. 18, 19}

1965 Baltisphaeridium aff. B. visbyense Brito, p. 3, pl. 1, fig. 4.

1972 Evittia remota (Deunff, 1955) remota Jardiné, Combaz, Magloire, Peniguel and Vachey, pp. 297-298, pl. 1, figs. 11, 12.

1973 Veryhachium sp. cf. V. lairdii Legault, pp. 53-54 (pars), pl. 12, figs. 3, 7, 11 (only).

1974 Veryhachium rabiosum Anan-Yorke, pp. 122-123, pl. 23, fig. 4.

1976 Diexallophasis remotum (Deunff, 1955) Brito, p. 753, fig. 6d.

1977 Diexallophasis remota (Deunff) Playford, pp. 1920 (pars), pl. 6, fig. 14 (only).

1981 Exochoderma arca Wicander and Wood, pp. 3839 , pl. 8, figs. 3, 4, pl. 9, figs. 1-3.

2008 Exochoderma sp. cf. E. arcaWicander and Wood; Zhu Huaicheng, Wicander and Marshall, p. 148, pl. 4, fig. 1.

\section{Occurrence. Samples HH1-HH14.}

Previous records. Exochoderma arca Wicander and Wood, 1981 has a stratigraphic range and occurrence as follows: Givetian, Ontario (Legault 1973); late Pragian-middle Givetian, Ontario (Playford 1977); Givetian, Ohio and Kentucky (Wicander and Wood 1981; Wood and Clendening 1985); late Givetian, lowa (Wicander and Wood 1997); Middle Devonian, Ohio (Wicander and Wright 1983) and Kentucky (Huysken et al. 1992); Middle Devonian, Brazil (Brito, 1965; 1976); Givetian-early Frasnian, Argentina (Ottone 1996; Amenábar et al. 2006); late Famennian, southeast Bolivia (Wicander et al. 2011); Givetian, central Poland (Turnau and Racki 1999); Givetian-Frasnian, Ghana (Anan-Yorke 1974); Emsian-Frasnian, Algerian Sahara (Jardiné et al. 1972); and Eifelian, China (Zhu Huaicheng et al. 2008; cf. designation).
Genus Gorgonisphaeridium Staplin, Jansonius and Pocock, 1965

Type species: Gorgonisphaeridium winslowiae Staplin, Jansonius and Pocock, 1965 [OD].

Gorgonisphaeridium inflatum Wicander and Wood, 1981

Plate 2, Figs. 16, 17

cf. 1954 Micrhystridium sericum Deunff, p. 1065, fig. 16 (nom. nud.).

cf. 1955 Micrhystridium sericum Deunff, p. 143, fig. 16 (nom. nud.).

cf. 1956 Micrhystridium sericum Deunff, p. 80, fig. 19 (nom. nud.).

cf. 1961 Micrhystridium sericum Deunff, p. 218.

1977 Gorgonisphaeridium sp. cf. Micrhystridium sericum Deunff, 1961; Playford, p. 24, pl. 9, figs. 17-21.

1981 Gorgonisphaeridium inflatum Wicander and Wood, p. 41, pl. 10, figs. 3-5.

Remarks. Gorgonisphaeridium inflatum Wicander and Wood, 1981 was erected because the description of Micrhystridium sericum Deunff, 1961 was very brief, generalized and seemingly based on only one specimen (Playford 1977).

Occurrence. Samples HH1, HH2, HH7, HH8, HH13.

Previous records. The cf. designations of Deunff (1954, 1955, 1956, 1961) are from imprecisely dated Early, but probably Middle Devonian samples from Ontario, whereas Gorgonisphaeridium sp. cf. Micrhystridium sericum (Deunff) Playford, 1977 is from the late Eifelian, Ontario (Playford 1977), and G. inflatum Wicander and Wood, 1981 occurs in the Givetian/Middle Devonian, Ohio (Wicander and Wood 1981; Wicander and Wright 1983).

Genus Hapsidopalla Playford, 1977 emend. Wicander and Wood, 1981

Type species: Hapsidopalla sannemannii (Deunff, 1957) Playford, 1977 [OD].

Hapsidopalla chela Wicander and Wood, 1981 Plate 3, Figs. 1, 2

Plate 3 (lámina 3). Acritarch photomicrographs. 1, 2, Hapsidopalla chelaWicander and Wood, 1981. 3, Micrhystridium stellatum Deflandre, 1942 ex Deflandre, 1945. 4, Leiofusa pyrena Wicander and Wood, 1981. 5, Multiplicisphaeridium ramusculosum (Deflandre, 1945) Lister, 1970. 6, Multiplicisphaeridium sp. A. 7, 8, Micrhystridium sp. A. 9, 10, Oppilatala sparsa Wicander and Wood, 1981. 11, Palacanthus ledanoisii (Deunff, 1957) emend. Playford, 1977. 12, 13, Uncinisphaera acanthaWicander and Wood, 1981. 14, Solisphaeridium sp. A. 15, 16, Navifusa bacilla (Deunff, 1955) Playford, 1977. Scale bars $=20 \mu \mathrm{m}$. 

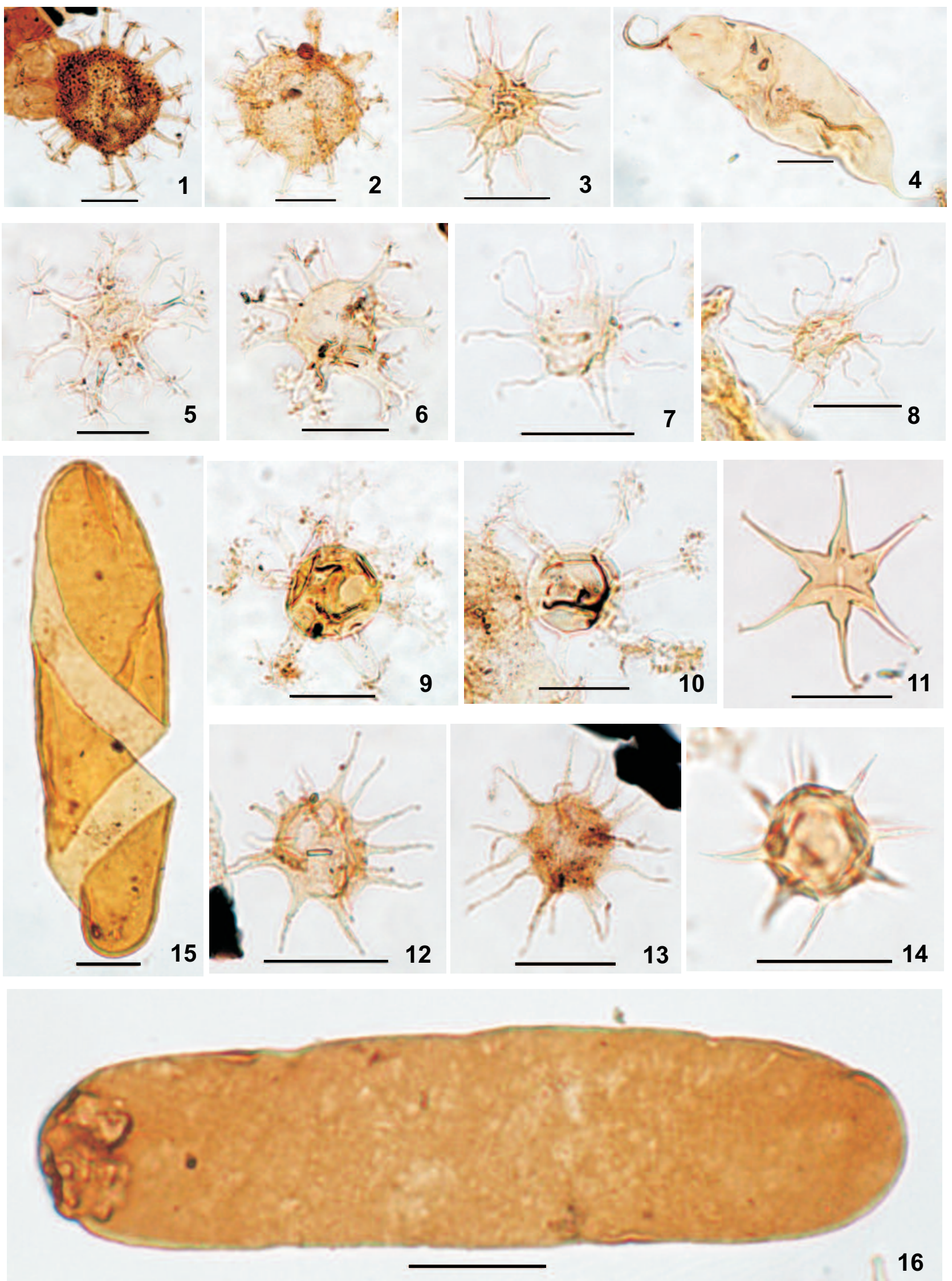
1981 Hapsidopalla chela Wicander and Wood, p. 46, pl. 10, fig. 8, pl. 11, figs. 1, 2.

Comparison. Hapsidopalla chela Wicander and Wood, 1981 differs from $H$. exornata (Deunff, 1967) Playford, 1977 and H. sannemannii (Deunff, 1957) Playford, 1977 in having typically more and longer distal spinose projections, and a finer vesicle rosette-like sculpture.

Occurrence. Samples HH1, HH2, HH4, HH6-HH10, $\mathrm{HH} 12, \mathrm{HH} 13$.

Previous records. This distinctive species has previously been reported from the Givetian, Ohio and Kentucky (Wicander and Wood 1981; Wood and Clendening 1985), and Middle Devonian, Ohio (Wicander and Wright 1983).

Genus Leiofusa Eisenack, 1938 emend. Eisenack, 1965, emend. Combaz, Lange and Pansert, 1967

Type species: Leiofusa fusiformis Eisenack (1934) ex Eisenack, 1938 [OD].

Leiofusa pyrena Wicander and Wood, 1981 Plate 3, Fig. 4

1981 Leiofusa pyrena Wicander and Wood, p. 45, pl. 12 , figs. $2-5$.

Occurrence. Samples HH1, HH2, HH4, HH6, HH9, $\mathrm{HH} 12, \mathrm{HH} 13$.

Remarks. Ottone (1996) considered that the specimen illustrated by Barreda (1986) as Leiofusa pyrena Wicander and Wood, 1981, should be referred simply to Leiofusa sp. (Ottone 1996, p. 126, 128; plate 7, figs. 7, 8). However, we disagree and note that Ottone (1996) included Leiofusa pyrena in his synonymy for Leiofusa sp.

Previous records. Leiofusa pyrena Wicander and Wood, 1981 has been recorded previously from the Givetian, Ohio (Wicander and Wood 1981), and Givetian-Frasnian boundary, Argentina (Barreda 1986).

Genus Micrhystridium Deflandre, 1937

Type species: Micrhystridium inconspicuum Deflandre, 1937 [OD].
Micrhystridium stellatum Deflandre, 1942 ex

Deflandre, 1945

Plate 3, Fig. 3

1942 Micrhystridium stellatum Deflandre, p. 476, figs. 7, 8 (nom. nud.).

1945 Micrhystridium stellatum Deflandre, p. 65, pl. 3, figs. 16-19.

Occurrence. Samples HH1-HH5, HH7-HH14.

Previous records. Micrhystridium stellatum Deflandre, 1942 ex Deflandre, 1945, cosmopolitan in distribution, has a stratigraphic range of Ordovician-Mesozoic.

Micrhystridium sp. A Wicander and Wood, 1981 Plate 3, Figs. 7, 8

1981 Micrhystridium sp. A Wicander and Wood, p. 49, pl. 13, fig. 4.

Remarks. Our specimens accord with Wicander and Wood's (1981) description of their Micrhystridium sp. $A$, and we follow them in leaving it in open nomenclature.

Occurrence. Samples HH1, HH2, HH4, HH7-HH10, $\mathrm{HH} 12$.

Previous records. Previously reported only from the Middle Devonian, Ohio (Wicander and Wood 1981; Wicander and Wright 1983).

Genus Multiplicisphaeridium Staplin, 1961 emend. Staplin, Jansonius and Pocock, 1965

Type species: Multiplicisphaeridium ramispinosum Staplin, 1961 [OD].

Multiplicisphaeridium ramusculosum (Deflandre, 1945) Lister, 1970

Plate 3, Fig. 5

1942 Hystrichosphaeridium ramusculosum Deflandre, p. 475 , figs. 2-6 (nom. nud.).

1945 Hystrichosphaeridium ramusculosum Deflandre, p. 63 , pl. 1, figs. 8-16, text-figs. $38,39$.

1961 Multiplicisphaeridium ramispinosum Staplin, p. 411 , pl. 48, fig. 24, text-fig. 9g-h.

1970 Multiplicisphaeridium ramusculosum (Deflandre, 1945) Lister, pp. 92-93, pl. 11, figs. 8, 11-14, text-fig. 25a. 
1974 Multiplicisphaeridium anastomosis Wicander, p. 29, pl. 14, figs. 7-9.

Occurrence. Samples HH1-HH14.

Previous records. Multiplicisphaeridium ramusculosum (Deflandre, 1945) Lister, 1970 is a cosmopolitan species with a stratigraphic range of Late Ordovician through Late Devonian.

\section{Multiplicisphaeridium sp. A Plate 3, Fig. 6}

Description. Vesicle originally spherical, circular to subcircular in outline, 19-21 $\mu \mathrm{m}$ in diameter; eilyma ca $0.5 \mu \mathrm{m}$ thick, surface psilate; 11-12 distinct, hollow, subcylindrical, psilate processes, opening into vesicle interior; proximal contacts slightly curved, thence near-cylindrical to point of furcation (ca $50-60 \%$ of distance from base); each bifurcant splitting to third, occasionally fourth order; distal tips sharply pointed, processes $2.4-4 \mu \mathrm{m}$ wide basally, 11-16 $\mu \mathrm{m}$ long. No excsytment structure observed.

Comparison and remarks. Multiplicisphaeridium sp. A superficially resembles $M$. ramusculosum, but differs in having more numerous and commonly longer processes that initially bifurcate ca $50-60 \%$ from their base, and typically have shorter distal tips. The limited number of well-preserved specimens necessitates informal species designation.

Occurrence. Samples HH2-HH5, HH7-10, HH12, HH13.

Genus Navifusa Combaz, Lange and Pansart, 1967

Type species: Navifusa navis (Eisenack, 1938) Eisenack, 1976 [OD].

Navifusa bacilla (Deunff, 1955) Playford, 1977 Plate 3, Figs. 15, 16

1955 Leiofusa bacillum Deunff, p. 148, pl. 4, fig. 2. 1977 Navifusa bacillum (Deunff, 1955) Playford, pp. 29-30, pl. 12, figs. 1-9.

For a complete synonymy and taxonomic discussion, see Fatka and Brocke (2008, pp. 117-118).

Occurrence. Samples HH1-HH14.

Previous records. Navifusa bacilla (Deunff, 1955) Playford, 1977 is a cosmopolitan Devonian
(Emsian-Famennian) species (Wicander and Wood 1981; Le Hérissé et al. 2000).

Genus Oppilatala Loeblich and Wicander, 1976

Type species: Oppilatala vulgaris Loeblich and Wicander, 1976 [OD].

Oppilatala sparsa Wicander and Wood, 1981 Plate 3, Figs. 9, 10

1981 Oppilatala sparsa Wicander and Wood, p. 54, pl. 14, figs. 2-4.

2008 Oppilatala sp. cf. O. sparsa Wicander and Wood; Zhu Huaicheng, Wicander and Marshall, p. 148, pl. 4, fig. 4.

Occurrence. Samples HH1-4, HH7-12.

Previous records. Oppilatala sparsa Wicander and Wood, 1981 has previously been reported from the Givetian, Ohio and Kentucky (Wicander and Wood 1981; Wood and Clendening 1985); late Givetian, lowa (Wicander and Wood 1997); and Eifelian, China (Zhu Huaicheng et al. 2008, cf. designation).

\section{Genus Ozotobrachion Loeblich and Drugg, 1968}

Type species: Ozotobrachion palidodigitatus (Cramer, 1967) Playford, 1977 [OD; as O. dactylos Loeblich and Drugg, 1968 (p. 130) = junior synonym of O. palidodigitatus vide Playford (1977, p. 31)].

\section{Ozotobrachion furcillatus (Deunff, 1955) Playford, 1977 \\ Plate 4, Fig. 1}

1955 Veryhachium furcillatum Deunff, p. 146, fig. 18. 1966a Veryhachium vipereum Deunff, pp. 80-81, pl. 6, figs. 69,70 , pl. 10, fig. 78 .

1968 Ozotobrachion dicros Loeblich and Drugg, p. 132, pl. 6, figs. 1-7.

?1971 Baltisphaeridium dicros Cramer, p. 170, pl. 13, fig. 189, fig. 52k.

1973 Multiplicisphaeridium dicros (Loeblich and Drugg, 1968); Eisenack, Cramer and Díez, pp. 605-606. 1973 Multiplicisphaeridium furcillatum (Deunff, 1955) Eisenack, Cramer and Díez, p. 649.

1975 Ozotobrachion? sp. Pöthe de Baldis, p. 512, pl. 3, fig. 4.

1977 Ozotobrachion furcillatus (Deunff, 1955) Playford, p. 31 , pl. 13, figs. 1-9, pl. 14, figs. 13-16. 

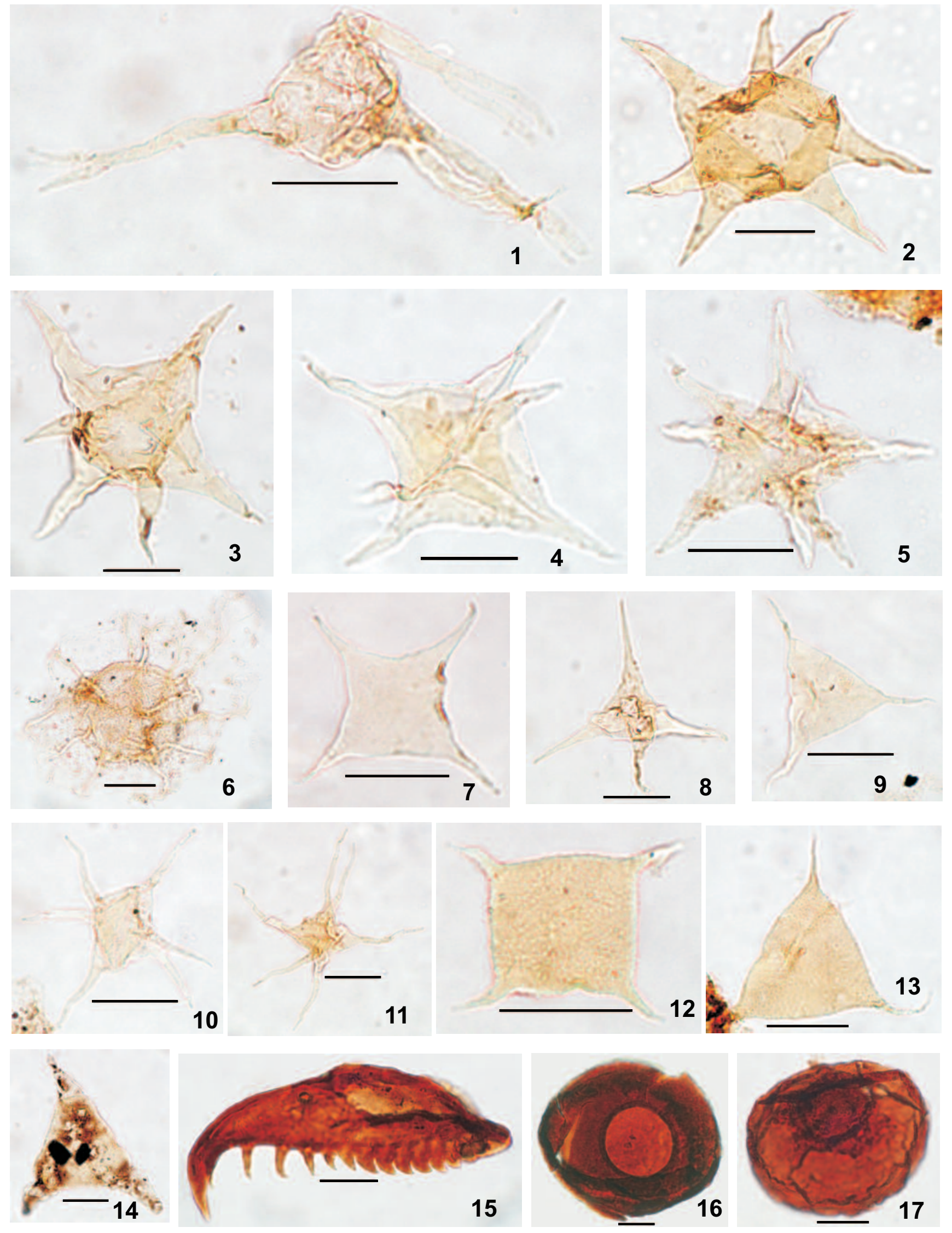
Occurrence. Samples HH1, HH4, HH5, HH7-HH9, $\mathrm{HH} 12$.

Comparison. See discussion in Playford (1977, p. 31) for distinction of present specimens from O. palidodigitatus.

Previous records. Ozotobrachion furcillatus (Deunff, 1955) Playford, 1977 has been recorded from the Middle Devonian, Ontario (Deunff 1955, 1966a); late Pragian-early Eifelian, Ontario (Playford 1977); Ludlovian, Florida (Cramer 1971; Cramer and Díez 1972); late Lochkovian, Oklahoma (Loeblich and Drugg 1968; Loeblich and Wicander 1976); Givetian, Ohio (Wicander and Wood 1981); late Givetian, lowa (Wicander and Wood 1997); Middle Devonian, Ohio (Wicander and Wright 1983); Wenlockian, Argentina (Pöthe de Baldis 1975); Ludlovian, northwest Spain (Cramer 1971; Cramer and Díez 1972); and Lochkovian, Algerian Sahara (Jardiné et al. 1974).

\section{Genus Palacanthus Wicander, 1974}

Type species: Palacanthus acutus Wicander, 1974 [OD].

Palacanthus ledanoisii (Deunff, 1957) emend. Playford, 1977

Plate 3, Fig. 11

1957 Veryhachium le danoisi Deunff, p. 9, fig. 9. 1962b Veryhachium stelligerum auct. non Deunff, 1957; Stockmans and Willière, p. 85, pl. 1, fig. 8, textfig. 10.

1966a Veryhachium sp. cf. V. stelligerum Stockmans and Willière, 1962b; Deunff, p. 78 (pars), pl. 3, figs. 35, 38, 39 (only).

1966b Veryhachium sp. cf. V. Ie danoisi Deunff; Deunff, p. 23, fig. 7.

1974 Estiastra pentagonalis Pöthe de Baldis, p. 71, pl. 2, fig. 5.

1977 Palacanthus ledanoisii (Deunff, 1957) Playford, p. 32, pl. 14, figs. 1-10.

1988 Palacanthus sp. cf. P. ledanoisii (Deunff, 1957)
Playford; Lu Li-chang and Wicander, p. 126, pl. 2, fig. 8.

\section{Occurrence. $\mathrm{HH} 1-\mathrm{HH} 5, \mathrm{HH} 7-\mathrm{HH} 13$.}

Previous records. Palacanthus ledanoisii (Deunff, 1957) Playford, 1977 has been recorded from the Middle Devonian, Ontario (Deunff 1957, 1966a); Emsian-middle Givetian, Ontario (Playford 1977); Givetian, Ohio and Kentucky (Wicander and Wood 1981; Wood and Clendening 1985); late Givetian, lowa (Wicander and Wood 1997); Middle Devonian, Ohio and Kentucky (Wicander and Wright 1983; Huysken et al. 1992); Middle Devonian, Paraguay (Pöthe de Baldis 1974); Givetian-Frasnian boundary, Argentina (Barreda 1986; Ottone 1996); Frasnian-early Famennian, Belgium (Stockmans and Williere 1962b; Martin 1985); Famennian, Portugal (Cunha and Oliveira 1989; Pereira et al. 2008); Devonian, Brittany, France (Deunff 1966a); undifferentiated Devonian, Tunisia (Deunff 1966b); late Frasnian-Famennian, Xinjiang, China (Lu Li-chang and Wicander 1988); Tournaisian/Tn1b, Xizang/Tibet (Gao Lianda 1986); and Frasnian, Western Australia (Playford and Dring 1981).

\section{Genus Polygonium Vavrdová, 1966}

Type species: Polygonium gracilis Vavrdová, 1966 [OD; M].

\section{Polygonium sp. A \\ Plate 4, Figs. 2, 3}

Description. Vesicle originally inflated, subcircular to subpolyhedral in outline, 30-32 $\mu \mathrm{m}$ in diameter; eilyma $<0.5 \mu \mathrm{m}$ thick, psilate; $6-8$ homomorphic psilate processes, $24-30 \mu \mathrm{m}$ long, \pm distinct from vesicle, freely communicating with vesicle interior; processes tapering from subcircular base, $6.4-12.8 \mu \mathrm{m}$ in diameter, to simple, acuminate tip; proximal contacts curved. No method of excystment observed.

Remarks and comparison. We assign this form to

Plate 4 (lámina 4). Photomicrographs of acritarchs (1-14), scolecodont (15), and chitinozoan (16, 17). 1, Ozotobrachion furcillatus (Deunff, 1955) Playford, 1977. 2, 3, Polygonium sp. A. 4, Stellinium comptum Wicander and Loeblich, 1977. 5, Stellinium micropolygonale (Stockmans and Willière, 1960) Playford, 1977. 6, Tunisphaeridium tentaculaferum (Martin, 1967) Cramer, 1971. 7, Veryhachium lairdii (Deflandre, 1946) ex Deunff, 1959. 8, Veryhachium europaeum Stockmans and Willière, 1960. 9, Veryhachium trispinosum (Eisenack, 1938) Stockmans and Willière, 1962 "complex." 10, Veryhachium pastoris Deunff, 1966. 11, Veryhachium polyaster Staplin, 1961. 12, Villosacapsula compta Wicander and Wood, 1997. 13, Villosacapsula rosendae (Cramer, 1964) Loeblich and Tappan, 1976. 14, Tyligmasoma alargada (Cramer, 1964) Playford, 1977. 15, Scolecodont. 16, 17, Hoegisphaera glabra Staplin, 1961. Scale bars $=20 \mu \mathrm{m}$. 
Polygonium Vavrdová, 1966 rather than to Micrhystridium Deflandre, 1937, partly because our specimens are larger than those that characterize Micrhystridium (generally $<20 \mu \mathrm{m}$ ) and, moreover, they display a somewhat distinct vesicle. Sarjeant and Stancliffe (1994, p. 42; 1996, p. 357) emended Polygonium and relegated a number of species to synonymy. However, Vavrdová's (1966, p. 413) diagnosis is followed here because the vesicle is polygonal in outline, with few $(15)$ relatively long, broadbased processes disposed regularly around the vesicle.

Polygonium sp. A differs from other species of the genus (e.g. P. gracilis Vavrdová, 1966; P. barredae Ottone, 1996) in having a mostly larger vesicle, generally fewer processes and wider proximal contacts with the vesicle. However, given the insufficiency of specimens, they are herein designated only informally.

Occurrence. Samples HH3, HH6-HH9, HH12.

Genus Solisphaeridium Staplin, Jansonius and Pocock, 1965 emend. Sarjeant, 1968

Type species: Solisphaeridium stimuliferum (Deflandre, 1968) Staplin, Jansonius and Pocock, 1965 [OD].

Remarks. On balance, we incline toward retaining Solisphaeridium Staplin, Jansonius and Pocock, 1965 emend. Sarjeant, 1968 as a genus distinct from Micrhystridium, notwithstanding the arguments expressed by Sarjeant and Stancliffe (1994, p. 12; 2000, p. 164) cf. Moczydlowska (1998, p. 44).

\section{Solisphaeridium sp. A \\ Plate 3, Fig. 14}

Description. Vesicle originally inflated, roundly polygonal to circular in outline, $14-16 \mu \mathrm{m}$ in diameter; eilyma $<1 \mu \mathrm{m}$ thick, psilate; processes numerous (15), clearly distinct from vesicle, psilate, \pm rigid, opening proximally into vesicle interior; processes discrete, homomorphic, spine-like in form, regularly tapering from angular proximal contacts $(1.6-2.4 \mu \mathrm{m}$ in basal diameter), to simple acuminate tips; process length 8-11 $\mu \mathrm{m}$. No excystment structure observed.

Remarks. Although resembling several described species, e.g. Solisphaeridium spinoglobosum (Staplin, 1961) Wicander, 1974, numerical insufficiency of the present specimens, and their somewhat nondescript morphology, preclude formal designation at the specific level.

Occurrence. Samples HH4, HH7, HH8, HH12.

Genus Stellinium Jardiné, Combaz, Magloire, Peniguel and Vachey, 1972

Type species: Stellinium micropolygonale (Stockmans and Willière, 1960) Playford, 1977 [OD, as Stellinium octoaster (Staplin, 1961) Jardiné, Combaz, Magloire, Peniguel and Vachey, 1972 by Jardiné et al. (1972, p. 298)].

Stellinium comptum Wicander and Loeblich, 1977 Plate 4, Fig. 4

1977 Stellinium comptum Wicander and Loeblich, pp. 151-152, pl. 9, figs. 1-6.

Occurrence. Samples HH1-HH3, HH7-HH10, HH12, $\mathrm{HH} 13$.

Previous records. Stellinium comptum Wicander and Loeblich, 1977 is a widely occurring species, with reports from the late Famennian-?Tournaisian, Saskatchewan (Playford and McGregor 1993); Givetian, Ohio and Kentucky (Wicander and Wood 1981; Wood and Clendening 1985); late Givetian, lowa (Wicander and Wood 1997); late Frasnian, lowa (Wicander and Playford 1985); late Famennian, Ohio (Molyneux et al. 1984); Late Devonian, Indiana (Wicander and Loeblich 1977); late Famennian, Illinois (Wicander and Playford 2013); late Givetian-early Frasnian, Argentina (Barreda 1986; Ottone 1996); late Frasnian-early Famennian, Belgium (Martin 1981, 1985); late Givetian-early Frasnian, Boulonnais, France (Deunff 1981; Le Hérissé and Deunff 1988); Famennian, Portugal (Cunha and Oliveira 1989; Pereira et al. 2008); late Famennian-Mississippian, South Wales (McNestry 1988); Frasnian, northern Iran (Ghavidel-syooki 1995); Frasnian, east-central Iran (Hashemi and Playford 1998); and late Frasnian-Famennian, Xinjiang, China (Lu Li-chang and Wicander 1988).

Stellinium micropolygonale (Stockmans and Willière, 1960) Playford, 1977

Plate 4, Fig. 5

1960 Micrhystridium micropolygonale Stockmans and Willière, p. 4, pl. 1, fig. 12. 
1961 Veryhachium octoaster Staplin, pp. 413-414, pl. 49, figs. 3, 4.

1962a Veryhachium micropolygonale (Stockmans and Willière, 1960) Stockmans and Willière, pp. 52-53, pl. 2, fig. 19, text-figs. 9a, b.

1962b Veryhachium sp. aff. Veryhachium octoaster Staplin; Stockmans and Willière, p. 85, pl. 1, fig. 7.

$1962 \mathrm{~b}$ Veryhachium vandenbergheni Stockmans and Willière, pp. $86-87$, pl. 2 , figs. 11,13 , text-figs. 5 a, b.

1972 Stellinium octoaster (Staplin, 1961) Jardiné, Combaz, Magloire, Peniguel and Vachey, pp. 298-299, pl. 2, figs. 1, 2.

1972 Stellinium octoaster (Staplin, 1961) var. elongatum Jardiné, Combaz, Magloire, Peniguel and Vachey, p. 299, pl. 2, figs. 3-5.

1975 Polyedryxium micropolygonale (Stockmans and Willière, 1960) Jux, p. 128, pl. 6, figs. 3a-c.

1977 Stellinium micropolygonale (Stockmans and Willière, 1960) Playford, pp. 36-37, pl. 18, figs. 7-9.

1983 Stellinium octoaster (Staplin, 1961) Jardiné, Combaz, Magloire, Peniguel and Vachey; Wicander and Wright, p. 11, fig. 5 (15).

For additional synonymy, see Wicander and Wood (1981, pp. 57-58).

\section{Occurrence. Samples HH1-HH5, HH7-HH14.}

Previous records. Stellinium micropolygonale (Stockmans and Willière, 1960) Playford, 1977 is a commonly occurring, globally distributed species with a stratigraphic range of Pragian-Famennian, and possibly lowermost Mississippian (Wicander and Wood 1981; Playford and McGregor 1993; González et al. 2005; Wicander and Playford 2013).

Genus Tunisphaeridium Deunff and Evitt, 1968

Type species: Tunisphaeridium concentricum Deunff and Evitt, 1968 [OD].

\section{Tunisphaeridium tentaculaferum (Martin, 1967) Cramer, 1971 \\ Plate 4, Fig. 6}

1961 'A Silurian hystrichosphere' Evitt, p. 396, pl. 4, fig. 11.

1967 Baltisphaeridium tentaculaferum Martin, p. 312, pl. 1, fig. 23, text-fig. 3 .

1968 Tunisphaeridium venosum Deunff (1966?) Cramer, p. 66, pl. 1, fig. 5.

1968 Tunisphaeridium concentricum Deunff and Evitt, p. 3 , pl. 1, figs. 1-12.

1971 Tunisphaeridium tentaculaferum (Martin, 1967)

Cramer, pp. 192-193, pl. 6, figs. 105, 106, 108, 109.
For expanded synonymy, see Wicander and Wood (1981, pp. 59-60).

\section{Occurrence. Samples HH1-HH14.}

Previous records. Tunisphaeridium tentaculaferum (Martin, 1967) Cramer, 1971 has a predominately northern hemisphere, Silurian-Late Devonian distribution. Previous reports are as follows: Silurian, Ontario (Thusu 1973a); late Pragian-middle Givetian, Ontario (Playford 1977); Givetian, Ontario (Legault 1973); Middle Silurian, New York (Evitt 1961; Deunff and Evitt 1968; Cramer 1968; Thusu 1973b; Thusu and Zenger 1974); Givetian, Ohio and Kentucky (Wicander and Wood 1981; Wood and Clendening 1985); late Givetian, lowa (Wicander and Wood 1997); Middle Devonian, Ohio (Wicander and Wright 1983); Wenlockian-Ludlovian?, Argentina (Pöthe de Baldis 1975); early Llandoverian-late Ludlovian, Gotland, Sweden (Le Hérissé 1989); Silurian, Belgium (Martin 1967); ?Silurian, France (Moreau-Benoit 1974); late Ludlovian, northwest Spain (Cramer 1967, 1971); late Llandoverian-Ludlovian, Turkey (Erkmen and Bozdogan 1979); Givetian, western Libya (MoreauBenoit 1984; Massa and Moreau-Benoit 1985); Wenlockian?-Ludlovian, Emsian?-Frasnian?, Algerian Sahara (Jardiné et al. 1974); and Emsian-Frasnian, Ghana (Anan-Yorke 1974).

\section{Genus Tyligmasoma Playford, 1977}

Type species: Tyligmasoma alargadum (Cramer, 1964) Playford, 1977 [OD].

Tyligmasoma alargada (Cramer, 1964) Playford, 1977 Plate 4, Fig. 14

1964 Triangulina alargada Cramer, pp. 334-335, pl. 6, figs. 1, 4, text-fig. 39 .

1973 Triangulina sp. cf. T. alargada Cramer; Legault, p. 58, pl. 11, figs. 11, 12.

1977 Tyligmasoma alargadum (Cramer, 1964) Playford, p. 38, pl. 19, figs. 1-6.

For additional synonymy, see Wicander and Wood (1981, p. 61).

Remarks. Although specifically identifiable specimens of Tyligmasoma alargada (Cramer, 1964) Playford, 1977 from the Hungry Hollow locality are not well preserved (see Plate 4, Fig. 14), they are sufficiently distinct for confident attribution.

Occurrence. Samples HH1, HH7, HH8, HH12. 
Previous records. Tyligmasoma alargada (Cramer, 1964) Playford, 1977 has a wide palaeogeographic distribution. Occurrences and stratigraphic ranges are as follows: Givetian, Ontario (Legault 1973); Emsian-Eifelian, Ontario (Playford 1977); Givetian, Ohio (Wicander and Wood 1981); late Givetian, lowa (Wicander and Wood 1997); Middle Devonian, Ohio (Wicander and Wright 1983); Pragian, northern Bolivia (Vavrdová et al. 1996); Early Devonian (= Zones R and S), Maranhão Basin, Brazil (Brito 1967a, b, c, 1969); Emsian, Uruguay (Pöthe de Baldis 1977); Silurian, France (Moreau-Benoit 1974); Lochkovian, Finistere, France (Deunff 1980); Ludlovian, Pragian-Emsian (in part) northwest Spain (Cramer 1964; Cramer and Díez 1976); late Famennian-Mississippian, South Wales (McNestry 1988); ?Late Devonian, Siberia (Sheshegova 1971); Givetian, western Libya (MoreauBenoit 1984); Emsian, Algerian Sahara (Jardiné 1972; Jardiné and Yapaudjian 1968; Jardiné et al. 1972, 1974); Emsian-Frasnian, Ghana (Anan-Yorke 1974); and Eifelian, China (Zhu Huaicheng et al. 2008).

\section{Genus Uncinisphaera Wicander, 1974}

Type species: Uncinisphaera lappa Wicander, 1974 [OD; M].

Uncinisphaera acantha Wicander and Wood, 1981 Plate 3, Figs. 12, 13

1981 Uncinisphaera acantha Wicander and Wood, p. 63 , pl. 16, figs. 5,6 .

Occurrence. Sample HH1, HH7, HH8.

Previous records. Uncinisphaera acantha Wicander and Wood, 1981 has previously been reported only from the Givetian, Ohio (Wicander and Wood 1981).

\section{Genus Veryhachium Deunff, 1959 ex Downie, 1959}

Type species: Veryhachium trisulcum (Deunff, 1954) Deunff 1959 [SD; Downie 1959, p. 62].

Veryhachium europaeum Stockmans and Willière, 1960

Plate 4, Fig. 8

1960 Veryhachium europaeum Stockmans and Willière, p. 3, pl. 2, fig. 25.

1962a Veryhachium legrandi Stockmans and Willière, p. 54 , pl. 1 , figs. 3,4 , text-figs. 11 a, b.
See Wicander and Wood (1981, pp. 64-65) for an extensive synonymy.

\section{Occurrence. Samples HH1-HH13.}

Previous records. Veryhachium europaeum Stockmans and Willière, 1960 is a cosmopolitan species with a stratigraphic range of Silurian-Famennian (Lu Li-chang and Wicander, 1988).

Veryhachium lairdii (Deflandre, 1946) ex Deunff, 1959 Plate 4, Fig. 7

1946 Hystrichosphaeridium lairdi Deflandre, fichier 1112,2 figs. (nom. nud.).

1959 Veryhachium lairdi (Deflandre, 1946) Deunff, p. 28, pl. 8, figs. 75-79.

1970 Veryhachium lairdii (Deflandre, 1946) ex Deunff; Loeblich, pp. 741-742.

For other synonymy, see Wicander and Wood (1981, pp. 65-66).

Remarks. We agree with Loeblich (1970, pp. 741-742) concerning the history of the naming and subsequent taxonomy of Veryhachium lairdii (Deflandre, 1946) ex Deunff, 1959.

Occurrence. Samples HH1-HH4, HH6-HH13.

Previous records. Veryhachium lairdii (Deflandre, 1946) ex Deunff, 1959, a predominantly northern hemisphere species, ranges from Ordovician through Devonian (Playford, 1977; Wicander and Wood 1981).

\section{Veryhachium pastoris Deunff, 1966b Plate 4, Fig. 10}

1966b Veryhachium pastoris Deunff, p. 22, fig. 4. 1997 Veryhachium pastore Deunff; Wicander and Wood, p. 137, pl. 3, fig. 12.

Occurrence. Samples HH2, HH4, HH7-HH9, HH12, $\mathrm{HH} 13$.

Previous records. Veryhachium pastoris Deunff, 1966 has been recorded from the Givetian, Ohio (Wicander and Wood 1981); late Givetian, lowa (Wicander and Wood 1997); Middle Devonian, Ohio (Wicander and Wright 1983); undifferentiated Devonian, Tunisia (Deunff 1966b); Givetian, western Libya (MoreauBenoit 1984); and Emsian-Frasnian, Ghana (AnanYorke 1974). 
Wicander, R. and Playford, G., 2017. Organic-walled microphytoplankton assemblage... Boletín Geológico y Minero, 128 (4): $839-883$

Veryhachium polyaster Staplin, 1961

Plate 4, Fig. 11

1961 Veryhachium polyaster Staplin, p. 413, pl. 49, fig. 20. 1961 Veryhachium polyaster var. hexaster Staplin, p. 413, pl. 49, fig. 19.

Occurrence. Samples HH1-HH10, HH12, HH13.

Previous records. Veryhachium polyaster Staplin, 1961 is a cosmopolitan species with a stratigraphic range of Pragian-Famennian (Playford and McGregor 1993; Ottone 1996). Heal and Clayton's (2008) unillustrated report is from the Lower Mississippian Hannibal Shale, Illinois.

Veryhachium trispinosum (Eisenack, 1938) Stockmans and Willière, 1962a "complex" Plate 4, Fig. 9

1938 Hystrichosphaeridium trispinosum Eisenack, pp. 14, 16, text-figs. 2, 3.

1962a Veryhachium trispinosum (Eisenack, 1938) Stockmans and Willière, pp. 46-47, pl. 2, figs. 25, 26, text-fig. 1.

See Wicander and Wood (1981, pp. 67-70 and Servais et al. (2007, pp. 191-203) for an extensive synonymy and discussion of this morpho-taxonomic "complex."

Occurrence. Samples HH1-HH13.

Previous records. The Veryhachium trispinosum (Eisenack, 1938) Stockmans and Willière, 1962a "complex" is cosmopolitan and ranges from Ordovician through Permian (Wicander and Wood 1981).

Genus Villosacapsula Loeblich and Tappan, 1976

Type species: Villosacapsula setosapellicula (Loeblich, 1970) Loeblich and Tappan, 1976 [OD].

Villosacapsula compta Wicander and Wood, 1997 Plate 4, Fig. 12

1997 Villosacapsula compta Wicander and Wood, p. 147, pl. III, figs. 8-11.

Occurrence. Samples HH2-4, HH6-HH10, HH12, HH13.

Previous records. Villosacapsula compta Wicander and Wood, 1997 has previously been reported exclusively from the late Givetian, lowa (Wicander and Wood 1997).
Villosacapsula rosendae (Cramer, 1964) Loeblich and Tappan, 1976

Plate 4, Fig. 13

1963 Veryhachium rosendae Cramer, pp. 215-216, pl. 1, figs. 4-6 (nom. nud.).

1964 Veryhachium rosendae Cramer, p. 313, pl. 13, figs. 6-9.

1976 Villosacapsula rosendae (Cramer, 1964) Loeblich and Tappan, p. 307.

Occurrence. Samples HH3, HH4, HH7, HH8, HH10$\mathrm{HH} 12$.

Previous records. Villosacapsula rosendae (Cramer, 1964) Loeblich and Tappan, 1976 is known from the Givetian, Ohio (Wicander and Wood 1981); Devonian, Bolivia (Kimyai 1983); Givetian-Frasnian, northern Bolivia (Vavrdová et al. 1996); Ludlovian-Emsian (in part), northwest Spain (Cramer 1963, 1964, 1967, 1971); and Frasnian, east-central Iran (Hashemi and Playford 1998).

\section{Chitinozoa}

Order Operculatifera Eisenack, 1931

Family Desmochitinidae Eisenack, 1931, emend. Paris, 1981

Subfamily Desmochitininae Paris, 1981

Genus Hoegisphaera Staplin, 1961, emend. Paris, Grahn, Nestor and Lakova, 1999

Type species: Hoegisphaera glabra Staplin, 1961

[OD].

Hoegisphaera glabra Staplin, 1961

Plate 4, Figs. 16, 17

1961 Hoegisphaera glabra Staplin, pp. 419-420, pl. 50, figs. 5-7.

1964 Hoegisphaera glabra Staplin; Jansonius, p. 912, pl. 2, fig. 18 (holotype re-illustrated).

Occurrence. Samples HH1-HH14.

Previous records. Hoegisphaera glabra Staplin, 1961 is a commonly occurring and widespread species with a stratigraphic range of Middle-Late Devonian (Staplin 1961; Urban 1972; Legault 1973; Wood 1974; Wood and Clendening 1985). 
Wicander, R. and Playford, G., 2017. Organic-walled microphytoplankton assemblage... Boletín Geológico y Minero, 128 (4): 839-883

\begin{tabular}{|c|c|c|c|c|c|c|c|c|c|c|c|c|c|c|}
\hline \multirow{2}{*}{\begin{tabular}{r|} 
Group \\
Formation \\
Sample number
\end{tabular}} & \multicolumn{14}{|c|}{ HAMILTON } \\
\hline & \multicolumn{3}{|c|}{ ARKONA } & \multicolumn{3}{|c|}{ HUNGRY HOLLOW } & \multicolumn{8}{|c|}{ WIDDER } \\
\hline \multicolumn{15}{|l|}{ Prasinophyte species } \\
\hline Cymatiosphaera canadense & & & $\mathrm{R}$ & $\mathrm{R}$ & & & $\mathrm{R}$ & $\mathrm{R}$ & C & $\mathrm{R}$ & & $\mathrm{R}$ & $\mathrm{R}$ & \\
\hline Cymatiosphaera cornifera & $\mathrm{R}$ & & & $\mathrm{R}$ & & & & & & & & $\mathrm{R}$ & & \\
\hline Cymatiosphaera winderi & $\mathrm{R}$ & $\mathrm{C}$ & & $\mathrm{R}$ & & $R$ & $R$ & $R$ & $\mathrm{R}$ & & & $\mathrm{R}$ & $R$ & \\
\hline Duvernaysphaera tenuicingulata & C & A & VA & VA & $R$ & C & C & C & A & VA & $\mathrm{R}$ & VA & A & $\mathrm{R}$ \\
\hline Leiosphaeridia sp. & $\mathrm{R}$ & VA & $\mathrm{C}$ & $\mathrm{C}$ & $\mathrm{R}$ & $\mathrm{R}$ & $\mathrm{R}$ & $\mathrm{R}$ & $\mathrm{R}$ & VA & $\mathrm{R}$ & VA & VA & VA \\
\hline Muraticavea munifica & $R$ & $\mathrm{R}$ & $R$ & $R$ & $R$ & $\mathrm{R}$ & $\mathrm{R}$ & $\mathrm{R}$ & C & & $R$ & $\mathrm{R}$ & C & \\
\hline Polyedryxium ambitum & & $\mathrm{R}$ & & & & $\mathrm{R}$ & $R$ & $R$ & $R$ & & & & $\mathrm{R}$ & \\
\hline Polyedryxium decorum & $\mathrm{C}$ & & & & & & & & & & & & & \\
\hline Polyedryxium embudum & & $\mathrm{R}$ & & & & & $\mathrm{R}$ & $\mathrm{R}$ & $\mathrm{R}$ & $\mathrm{R}$ & $R$ & & $\mathrm{C}$ & \\
\hline Ammonidium sp. A & $\mathrm{R}$ & $\mathrm{R}$ & $\mathrm{R}$ & $\mathrm{C}$ & $R$ & $R$ & $R$ & $\mathrm{R}$ & $\mathrm{C}$ & $R$ & & $R$ & $\mathrm{C}$ & \\
\hline Baltisphaeridium distentum & $\mathrm{R}$ & $\mathrm{C}$ & $\mathrm{R}$ & C & $\mathrm{R}$ & $\mathrm{R}$ & $\mathrm{C}$ & $\mathrm{C}$ & $A$ & $\mathrm{C}$ & $R$ & $\mathrm{C}$ & $\mathrm{R}$ & \\
\hline Daillydium pentaster & $\mathrm{R}$ & $\mathrm{R}$ & & A & & $\mathrm{R}$ & $\mathrm{R}$ & $\mathrm{R}$ & & $\mathrm{R}$ & $\mathrm{R}$ & $\mathrm{R}$ & $\mathrm{R}$ & \\
\hline Diexallophasis simplex & $R$ & & & & & $\mathrm{R}$ & & & & & & & $\mathrm{R}$ & \\
\hline Eisenackidium appendiculum & $\mathrm{C}$ & C & $R$ & A & & $\mathrm{C}$ & & & $R$ & & & $R$ & $\mathrm{R}$ & \\
\hline Estiastra rhytidoa & $\mathrm{R}$ & & & & & & & & $\mathrm{R}$ & & & & $\mathrm{R}$ & \\
\hline Exochoderma arca & $A$ & VA & $R$ & A & $\mathrm{R}$ & $\mathrm{C}$ & C & C & $\mathrm{C}$ & A & C & $\mathrm{R}$ & $R$ & \\
\hline Gorgonisphaeridium inflatum & $\mathrm{A}$ & $\mathrm{R}$ & & & & & $R$ & $R$ & & & & $\mathrm{R}$ & & \\
\hline Hapsidopalla chela & $\mathrm{C}$ & $\mathrm{R}$ & & $\mathrm{R}$ & & $\mathrm{R}$ & $\mathrm{R}$ & $\mathrm{R}$ & $\mathrm{R}$ & $\mathrm{R}$ & & C & $\mathrm{R}$ & \\
\hline Leiofusa pyrena & $R$ & $R$ & & $\mathrm{R}$ & & & & & $R$ & & & $\mathrm{R}$ & $\mathrm{R}$ & \\
\hline Micrhystridium stellatum & $R$ & $\mathrm{C}$ & $\mathrm{R}$ & $\mathrm{C}$ & $\mathrm{R}$ & & C & $\mathrm{C}$ & $A$ & $\mathrm{C}$ & $\mathrm{R}$ & $A$ & $\mathrm{R}$ & $\mathrm{R}$ \\
\hline Micrhystridium sp. A & $R$ & $\mathrm{R}$ & & $R$ & & & $\mathrm{R}$ & $\mathrm{R}$ & $\mathrm{R}$ & $R$ & & $\mathrm{R}$ & & \\
\hline Stellinium comptum & $\mathrm{C}$ & $\mathrm{R}$ & $\mathrm{R}$ & & & & $\mathrm{R}$ & $\mathrm{R}$ & $\mathrm{C}$ & $\mathrm{R}$ & & C & C & \\
\hline Stellinium micropolygonale & C & C & $\mathrm{R}$ & $\mathrm{R}$ & $\mathrm{R}$ & & C & C & VA & $\mathrm{R}$ & $\mathrm{R}$ & $\mathrm{C}$ & $\mathrm{C}$ & $\mathrm{R}$ \\
\hline Tunispheridium tentaculaferum & C & C & $\mathrm{R}$ & $\mathrm{C}$ & $\mathrm{R}$ & $\mathrm{R}$ & C & $\mathrm{C}$ & $\mathrm{C}$ & $\mathrm{R}$ & $\mathrm{R}$ & $\mathrm{R}$ & $\mathrm{C}$ & $\mathrm{R}$ \\
\hline Tyligmasoma alargada & $\mathrm{R}$ & & & & & & $\mathrm{R}$ & $\mathrm{R}$ & & & & $\mathrm{R}$ & & \\
\hline Uncinisphaera acantha & $\mathrm{C}$ & & & & & & $R$ & $R$ & & & & & & \\
\hline Veryhachium europaeum & C & A & $R$ & C & $R$ & $\mathrm{R}$ & C & C & VA & A & $\mathrm{R}$ & C & $\mathrm{R}$ & \\
\hline Veryhachium lairdii & $\mathrm{R}$ & A & $\mathrm{R}$ & C & & $\mathrm{R}$ & $\mathrm{R}$ & $\mathrm{R}$ & $\mathrm{C}$ & C & $\mathrm{R}$ & VA & $\mathrm{R}$ & \\
\hline Veryhachium pastoris & & $\mathrm{R}$ & & C & & & $\mathrm{R}$ & $\mathrm{R}$ & $\mathrm{R}$ & & & $\mathrm{C}$ & $\mathrm{R}$ & \\
\hline Veryhachium polyaster & $\mathrm{R}$ & VA & C & $A$ & $\mathrm{R}$ & $\mathrm{R}$ & $A$ & A & C & A & & VA & $\mathrm{R}$ & \\
\hline Veryhachium trispinosum "complex" & $\mathrm{C}$ & VA & $\mathrm{C}$ & VA & $\mathrm{R}$ & $\mathrm{R}$ & $\mathrm{C}$ & $\mathrm{C}$ & $\mathrm{C}$ & A & C & $\mathrm{R}$ & $\mathrm{R}$ & \\
\hline Villosacapsula compta & & $\mathrm{R}$ & $\mathrm{R}$ & $\mathrm{R}$ & & $\mathrm{R}$ & $\mathrm{C}$ & C & $\mathrm{R}$ & $\mathrm{R}$ & & $\mathrm{C}$ & $\mathrm{R}$ & \\
\hline Villosacapsula rosendae & & & $\mathrm{R}$ & $\mathrm{R}$ & & & $\mathrm{R}$ & $\mathrm{R}$ & & $\mathrm{R}$ & $\mathrm{R}$ & $R$ & & \\
\hline \multicolumn{15}{|l|}{ Chitinozoan species } \\
\hline Hoegisphaera glabra & $\mathrm{R}$ & VA & C & VA & $\mathrm{R}$ & $\mathrm{R}$ & $R$ & $\mathrm{R}$ & $R$ & A & C & A & $A$ & $\mathrm{R}$ \\
\hline
\end{tabular}

Table 1. Distribution of microphytoplankton taxa within the sampled Arkona, Hungry Hollow and Widder formations at Hungry Hollow, Ontario, Canada. Relative abundance of taxa is based on counts from three $>50 \mu \mathrm{m}$ and three 20-50 $\mu \mathrm{m}$ slides, or three $>20 \mu \mathrm{m}$ slides (see Materials and methods section). VA (very abundant) = > 100 specimens; A (abundant) $=51-100$ specimens; $\mathrm{C}$ (common) = 11-50 specimens and $\mathrm{R}$ (rare) $=10$ or fewer specimens. The taxa are arranged alphabetically within the prasinophytes, acritarchs and chitinozoans. Tabla 1. Distribución de los taxones de microfitopláncton a lo largo de las formaciones Arkona, Hungry Hollow y Widder, Ontario, Canadá. La abundancia relativa de taxones está basada en conteos de tres láminas con residuos $>50 \mu m$ y tres con residuos de 20-50 $\mu$ m, o tres con residuos $>20 \mu \mathrm{m}$ (ver la sección de materiales y métodos). VA (muy abundante) = > 100 especímenes; $A$ (abundante) = 51-100 especímenes; $C$ (común) = 11-50 especímenes y $R$ (raro) $=10$ o menos especímenes. Los taxones están ordenados alfabéticamente considerando cada una de las tres categorías estudiadas: prasinofitos, acritarcos y quitinozoos. 


\section{Composition of the palynoflora}

The palynoflora of the Middle Devonian (Givetian) Arkona, Hungry Hollow and Widder formations consists of prasinophyte phycomata, acritarchs, chitinozoans, scolecodonts and some miospores. The organic-walled microphytoplankton component includes 16 prasinophyte species (two of which are designated informally) that are distributed among nine genera. Acritarchs comprise 27 identified species and five informally named species; these are allocated to 25 genera. One chitinozoan species is also described. In addition, other chitinozoans and a few miospores and scolecodonts are also present, but unnamed.

Excluding the single named chitinozoan taxon (Plate 4, Figs. 16, 17), acritarchs dominate the palynoflora at both generic and specific levels (83\% and $67 \%$ respectively). With the exception of sample $\mathrm{HH} 14$, where diversity and abundance significantly decrease, the most common taxa occur regularly throughout the sampled section (Table 1).

Disregarding Leiosphaeridia sp. and Tasmanites sp., the five most abundant species are, in decreasing order: Multiplicisphaeridium ramusculosum, Navifusa bacilla, Duvernaysphaera tenuicingulata, Polyedryxium pharaone and $D$. angelae. The least abundant species, having only two-four occurrences throughout the section and a rare abundance level per sample are, in decreasing quantitative order: Arkonites bilixus, Solisphaeridium sp. A, Tyligmasoma alargada, Cymatiosphaera cornifera, Diexallophasis simplex, Estiastra rhytidoa and Dictyotidium variatum. The remaining taxa fluctuate in their occurrences through the section, ranging from rare to very abundant (Table 1).

Chitinozoans, scolecodonts and indifferently preserved miospores also occur in the Arkona/Hungry Hollow/Widder assemblage, although in much lesser proportions than the acritarchs and prasinophytes. Overall, the marine component of the palynoflora is predominant, with the terrestrial (miospore) contribution being very minor.

\section{Palynostratigraphic correlations and age}

The palynoflora retrieved from the Hungry Hollow locality is characterized by a diverse and abundant acritarch/prasinophyte assemblage (Table 1) including many cosmopolitan species, together with taxa restricted to North America or the northern hemisphere. Although no new species are described herein, several taxa that are left in open nomenclature are probably new species, but poor preservation and/or

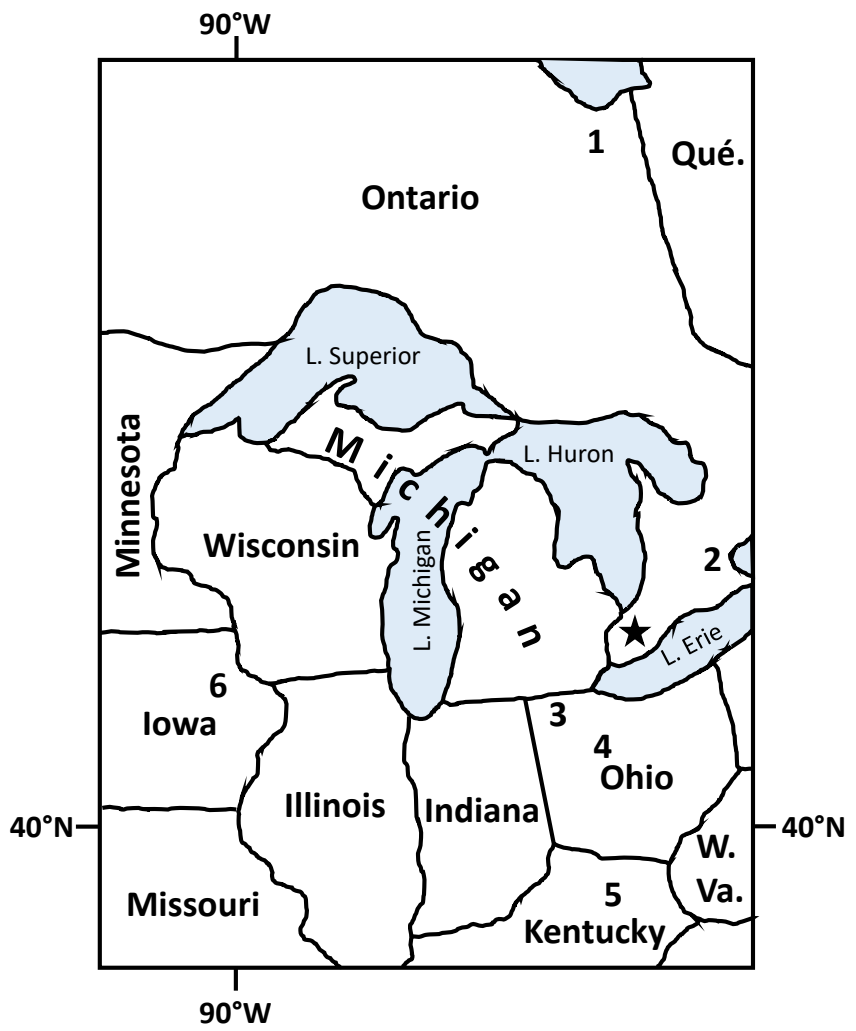

Figure 4. Geographic occurrences of well-dated Middle Devonian organic-walled microphytoplankton assemblages in North America. Star symbol denotes Hungry Hollow collecting site in southwestern Ontario (Arkona, Hungry Hollow and Widder formations of present study); W.Va = West Virginia; Qué = Québec. Key to numbered locations (generalized) and data sources: 1 , Eifelian-Givetian Kwataboahegan, Moose River, Murray Island and Williams Island formations, Moose River Basin, Ontario (Playford 1977); 2, Middle Devonian Hamilton Group, southwestern Ontario (Legault 1973); 3, Givetian Silica Formation, Ohio (Wicander and Wood 1981); 4, Middle Devonian Columbus and Delaware limestones, Ohio (Wicander and Wright 1983); 5, Givetian Boyle Dolomite, Kentucky (Wood and Clendening 1985); 6, Givetian Rapid Member of Cedar Valley Formation, lowa (Wicander and Wood 1997).

Figura 4. Situación geográfica de los puntos en donde se han encontrado asociaciones microplanctónicas de pared orgánica en Norte América. La estrella indica la zona de tma de muestras de la localidad de Hungry Hollow en el suroeste de Ontario (Arkona, Hungry Hollow y Widder de este estudio); W.Va = Oeste de Virginia; Qué = Québec. Clave de numeración de las localidades mencionadas en el texto y fuente de datos: 1, Eiffeliense-Givetiense de Kwataboahegan, Río Moose, formaciones Murray Island y Williams Island, Cuenca del Río Moose, Ontario (Playford 1977); 2, Devónico Medio del Grupo Hamilton Group, suroeste de Ontario (Legault 1973); 3, Givetiense de Silica Shale, Ohio (Wicander and Wood 1981); 4, devónico Medio de los limestones de Columbus y Delaware, Ohio (Wicander and Wright 1983); 5, Givetiense de Boyle Dolomite, Kentucky (Wood and Clendening 1985); 6, Givetiense del Miembro Rapid de la Formación Cedar Valley, lowa (Wicander and Wood 1997).

lack of sufficient specimens preclude their formal designation. As discussed below, the assemblage, as a whole, corroborates the Middle Devonian (Givetian) 
age for the Arkona, Hungry Hollow and Widder formations that has hitherto been based on lithostratigraphy and their contained marine invertebrate fauna (e.g. Stumm et al. 1956; Driscoll et al. 1965; Winder and Stanford 1972; Landing and Brett 1987).

A close similarity is evident in terms of species shared among Middle Devonian organic-walled microphytoplankton assemblages within North America (Fig. 4), and to a lesser extent elsewhere. Detailed comparison of the Arkona/Hungry Hollow/Widder palynoflora with correspondingly abundant, diverse and well-preserved Middle Devonian acritarch/prasinophyte assemblages from Laurentia and other palaeocontinents is provided in a subsequent section.

As cited earlier, there have been 17 publications describing Middle Devonian acritarch/prasinophyte assemblages or occurrences within North America. However, only six papers are of interest here (Fig. 4). These six assemblages show a degree of similarity between $59-96 \%$ commonalty with the palynoflora of the present study. As would be expected from the close geographic proximity, a high percentage (89\%) of taxa recorded herein are shared with the Hamilton Group from southwestern Ontario (Legault 1973). An even higher percentage (96\%) of co-occurring species link the present assemblage with that of the Givetian Boyle Dolomite from Kentucky (Wood and Clendening 1985).

Based on the high number of common species among the six Middle Devonian acritarch/prasinophyte assemblages from North America, it is clear that the palynofloras represent a distinct palynostratigraphic entity, incorporating both short- and long-ranging species, thereby facilitating stratigraphic correlation within the Laurentian palaeocontinent. In addition, many of the organic-walled microphytoplankton taxa from the Hungry Hollow locality, including several with restricted stratigraphic ranges, are globally distributed, allowing for intercontinental correlation and recognition of open oceanic connections.

Four distinctive species, occurring only in Laurentia and restricted there to the Eifelian-Givetian (Gorgonisphaeridium inflatum and Hapsidopalla chela) and Givetian (Uncinisphaera acantha and Villosacapsula compta), are biostratigraphically effi-

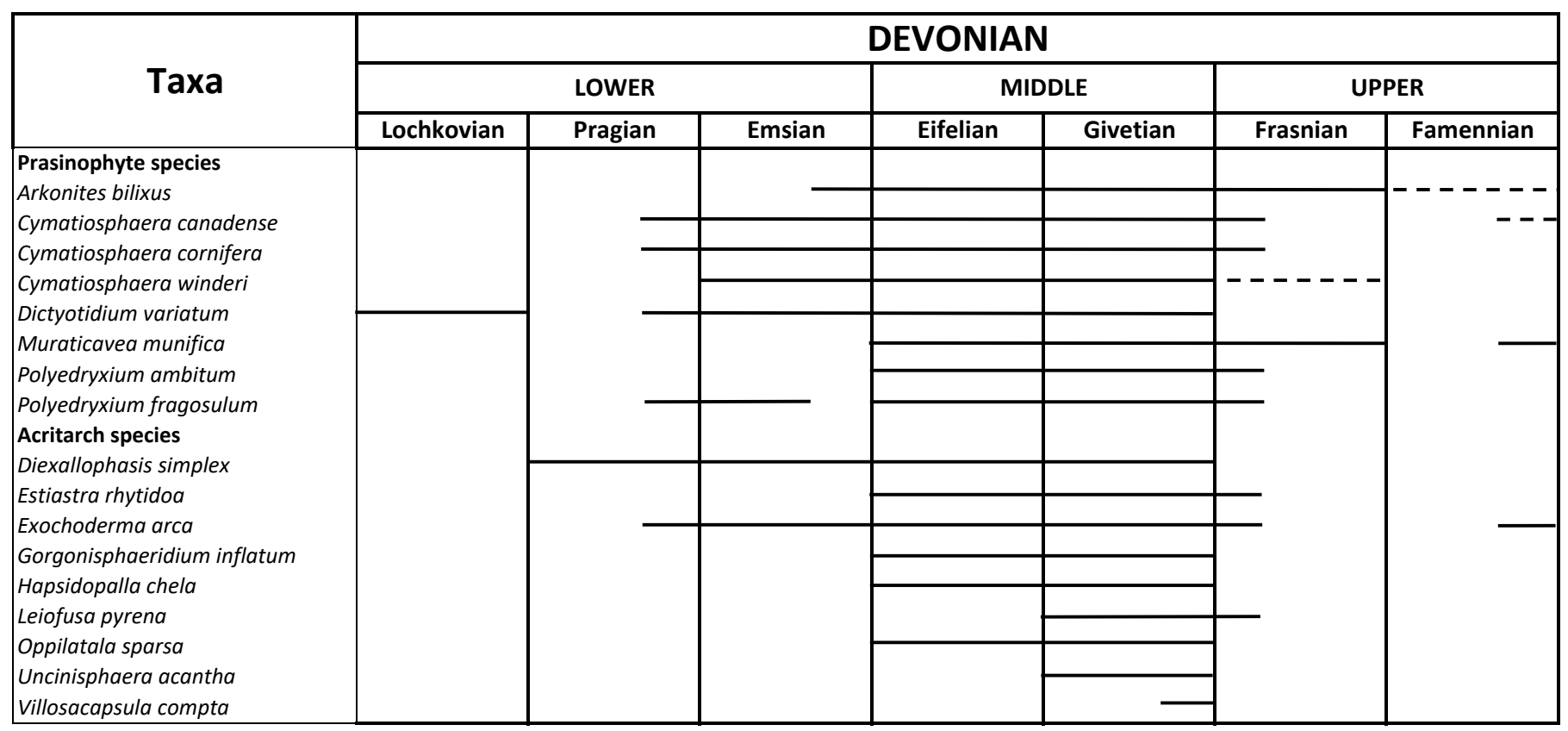

Figure 5. Chronostratigraphic ranges of selected prasinophyte and acritarch species present in the Arkona, Hungry Hollow and Widder formations, southwestern Ontario. Taxa and ranges are based on illustrated specimens from stratigraphically documented occurrences. See Systematic palaeontology section for sources of data. Solid lines indicate known stratigraphical ranges; dashed lines are probable occurrences.

Figura 5. Rangos cronoestratigráficos de especies seleccionadas de prasinofitos y acritarcos presentes en las formaciones Arkona, Hungry Hollow y Widder, suroeste de Ontario. Los taxones y sus rangos estratigráficos están basados en especímenes ilustrados a partir de aparaciones estratigráficamente bien documentadas. Ver la sección de Paleontología Sistemática para consultar la fuente de los datos. Las líneas continuas indican rangos estratigráficos bien conocidos; las líneas discontinuas señalan apariciones probables. 
caceous (Fig. 5). Two species - Leiofusa pyrena and Oppilatala sparsa - are constrained to the Givetian in North America, and are also reported respectively from Givetian-Frasnian boundary beds in Argentina (Barreda 1986) and possibly Eifelian of China (Zhu Huaicheng et al. 2008 as Oppilatala cf. O. sparsa) (Fig. 5). Both Estiastra rhytidoa and Polyedryxium ambitum occur in the Eifelian-Givetian of North America, with $E$. rhytidoa present in the Givetian-early Frasnian in Argentina (Barreda 1986; Rubinstein 1999, 2000) and $P$. ambitum restricted to the late Givetian-early Frasnian in Argentina (Barreda 1986; Ottone 1996) (Fig. 5).

The high percentage of co-occurring Givetian or undifferentiated Middle Devonian acritarch/prasinophyte species recorded from the aforementioned six North American localities, corroborate a Givetian age for the Arkona, Hungry Hollow and Widder formations, and are in agreement with Middle Devonian lithostratigraphic and invertebrate faunal studies. This palynoflora, in toto, also enables palynologic correlation between Laurentia and other palaeocontinents during the Middle Devonian.

\section{Paleoenvironmental synthesis}

Interpreting palaeoenvironments involves the application of modern principles of sedimentology, biology, complex physico-chemical seawater relationships and hydrodynamic factors affecting water masses and circulation, to name a few. Sedimentary facies and the accompanying association of megaand micro-invertebrates, phytoplankton and dispersed spores-pollen can all facilitate interpretation of past depositional and environmental conditions. In particular, the minute size and durability of microphytoplankton enhance their usefulness in palaeoenvironmental reconstructions.

Fluctuations in the inverse relationship between marine microphytoplankton and land-derived sporespollen is well established and has been used for determining proximity to palaeoshorelines and the recognition of transgressive/regressive cycles (Sarmiento 1957; Upshaw 1964; Gray and Boucot 1972; Wicander and Wood 1997).

Various models based on microphytoplankton diversity, assemblage composition, morphotype and form-classes have been proposed for identifying and interpreting palaeoshorelines, inshore-offshore environments and water depths. Staplin (1961) was the first to show a relationship between acritarch morphotypes and diversity, on the one hand, and distance from a Devonian reef on the other. Subsequent stu- dies confirming the value of applying the above methods to palaeoenvironmental syntheses include papers by such authors as Smith and Saunders (1970), Thusu (1972), Jacobson (1979), Colbath (1980), Dorning (1981), Al-Ameri (1982), Vecoli (2000), Li Jun et al. (2004) and Stricanne et al. (2004).

Jacobson (1979) constituted the first semi-quantitative attempt at palaeoenvironmental interpretation by means of acritarch diversity and abundance. He divided the acritarchs from Middle and Upper Ordovician rocks of the Cincinnati and New York regions into seven morphologically-defined classes. He graphically plotted the relative abundance of the classes in the sections studied, showing that the proportions and composition of the classes relate to facies differences in both regions. Jacobson (1979) concluded that by grouping some of the classes together, three distinct palaeoenvironmental settings could be recognized. The leiosphaerid class represented a shallow, nearshore environment; the peteinosphaerid-Dicommopalla class reflected a shoal environment; and the remainder of the classes (baltisphaerid-veryhachid-Polygonium-micrhystridid) signified an offshore, open-marine situation. Furthermore, the acritarch abundance fluctuations closely mirrored the variations in relative abundances of chitinozoans and conodonts from the same studied sections.

Dorning (1981) adopted a different semi-quantitative technique to establish a relationship between acritarch diversity and morphotype variation vis-à-vis palaeoenvironment. He examined these variables for rocks from the Silurian (Ludlovian) shelf of South Wales and the Welsh borderland, and recognized three assemblages indicative of increasing depth and distance from the palaeoshoreline: viz. a nearshore environment characterized by low diversity and abundant sphaeromorphs; an offshore, shelf assemblage with high diversity and no dominant taxon; and a deeper water assemblage, also of low diversity, and with a preponderance of sphaeromorphs.

Al-Ameri (1983) qualitatively defined 'palynofacies' as being symptomatic of distance from palaeoshorelines in Silurian strata of the Rhadames Basin, Libya. The palynofacies were based on the presence, diversity, abundance and morphologies of miospores, acritarchs and chitinozoans.

Vecoli (2000) applied fluctuations in acritarch diversity, relative abundances and morphotype classes to reconstruct changing palaeoenviromental conditions for Cambrian-Ordovician sedimentary successions of the northern Sahara Platform. He concluded that these three variable factors were influenced by changes in depositional facies; and moreover, that 
Wicander, R. and Playford, G., 2017. Organic-walled microphytoplankton assemblage... Boletín Geológico y Minero, 128 (4): $839-883$

certain stratigraphically important acritarch taxa appeared to be facies-sensitive.

Inshore-offshore models of microphytoplankton distribution have been proposed and applied to palaeonvironmental syntheses of Palaeozoic sedimentary sequences by such authors as Li Jun et al. (2004) and Stricanne et al. (2004). Although recognizing that nearshore-offshore models might be somewhat simplistic and affected by a host of variables, they appear nonetheless to allow a first-order level of analysis. Using the above principles, many authors have applied these models to adduce palaeoenvironmental changes and to recognize transgressive/ regressive cycles (e.g. Wicander and Wood 1997).

Applying the general principles of palaeoenvironmental interpretation, the lithologies and associated shelly faunas (e.g. corals, brachiopods, trilobites, crinoids) of the Arkona, Hungry Hollow and Widder formations, as reported by Mitchell (1967) and Wright and Wright (1961), indicate a normal, low-energy, offshore, marine environment. The prasinophyte and acritarch assemblages reported here, are also clearly in accord with that interpretation.

In terms of relative abundance of the palynomorph taxa recovered from the 14 samples at the Hungry Hollow location (Table 1), the following designations per sample are used: rare (10 or fewer specimens); common (11-50 specimens); abundant (51-100 specimens) and very abundant ( $>100$ specimens).

The diversity of the assemblage ranges from a low of 10 species (sample HH14) to a high of 41 species (samples $\mathrm{HH7}$ and $\mathrm{HH} 8$ ), with five samples each containing between 38 and 40 species per sample (Table 1). As expected, the higher diversities recorded (28 to 41 taxa per sample) correspond to the shale, calcareous shale, and argillaceous, fine-grained limestone lithofacies (samples $\mathrm{HH} 1,3,7,8,9,10,13$ ). Conversely, two of the lower-diversity samples (HH5, 11), both limestones, yielded 23 and 21 species respectively. There were also exceptions to the generally accepted high-diversity/fine-grained sediment and low-diversity/coarser grained or crystalline rocks model. For example, samples $\mathrm{HH} 2,4$ and 12, all collected from limestone layers, had some of the highest diversities $(38,39,40$ respectively), whereas the lowest-diversity sample (10 species) was an argillaceous limestone (HH14).

In terms of morphotypes, the most consistently high-abundance taxa are, in order of decreasing abundance: Multiplicisphaeridium ramusculosum, Leiosphaeridia sp., Navifusa bacilla, Duvernaysphaera tenuicingulata, Polyedryxium pharaone, D. angelae, Exochoderma arca, Micrhystridium stellatum, Veryhachium trispinosum "complex," V. polyaster, Stellinium micropolygonale, Baltisphaeridium distentum and Tunisphaeridium tentaculaferum.

The Arkona/Hungry Hollow/Widder assemblage complies with the baltisphaerid-veryhachidPolygonium-micrhystridid morphological class that Jacobson (1979) associated with an offshore, openmarine environment. Furthermore, Dorning (1981) concluded that offshore, shelf assemblages display high diversity (typically 25-60 species) and moderate abundance with no one taxon dominating. Common genera include: Cymatiosphaera, Diexallophasis, Micrhystridium, Multiplicisphaeridium and Leiosphaeridia. All of Dorning's criteria for an offshore, open-marine environment are exemplified by the palynologic assemblage documented herein.

Various authors (e.g. Hashemi and Playford 1998; Wicander et al. 1999; Vecoli 2000; Stricanne et al. 2004; Playford and Wicander 2006; Yan Kui et al. 2013; Wicander and Playford 2013) have applied similar palynologic criteria - i.e. variation in abundance, diversity and morphotypes of the organic-walled microphytoplankton - to palaeoenvironmental syntheses of marine successions. Our findings and interpretations with respect to the Arkona/Hungry Hollow/Widder assemblage essentially mirror and complement the conclusions reached in those previous studies.

In addition to prasinophytes and acritarchs, chitinozoans were also encountered in the studied samples, although not approaching the abundance or diversity of the organic-walled microphytoplankton taxa. The co-occurring miospores constitute only a very small portion of the overall palynomorph cohort. Their defective preservation very likely reflects degradation during transportation to the offshore environment.

In summary, application of all the factors previously discussed indicate that the sediments of the Arkona, Hungry Hollow and Widder formations accumulated in a well-oxygenated, marine, offshore, shelf environment, as embodied by the fine-grained sediment hosting the palynologic assemblage, with periodic regressions favouring the development of a reeftype environment that produced coarser-grained, coralline limestones.

\section{Comparison with other Middle Devonian organic- walled microphytoplankton assemblages}

Published accounts of Middle Devonian organicwalled microphytoplankton assemblages are not as extensive, stratigraphically definitive, or palaeogeographically widespread as might be expected. Many 
reports, especially early ones, dated the assemblages no more precisely than Middle Devonian (i.e. without attribution to the constituent Eifelian and/or Givetian stages). Most recent papers, however, are better documented stratigraphically, with enhanced emphasis on taxonomic identifications, thereby resulting in more refined biostratigraphic and palaeogeographic interpretations.

In the following two sub-sections, we compare our Givetian prasinophyte/acritarch suite to other Middle Devonian assemblages reported from, and beyond, North America. Because of some differences among authors - in particular, the degree of morphologic variation constituting species - comparison of commonalty between assemblages tends to be rather more qualitative than quantitative.

It is noteworthy that a close similarity between assemblages does not necessarily connote stratigraphic equivalence. It could reflect, in part, mutual presence of long-ranging, cosmopolitan species. On the other hand, a low similarity expressed as a percentage in common between two assemblages might be a consequence of differences in palaeoecologic or palaeoenvironmental conditions, palaeogeographic distribution, or even taxonomic and nomenclatural differences among authors.

In determining the degree of similarity between our acritarch/prasinophyte assemblage and others, we counted the number of named species (including those designated cf.) in the assemblage if we considered them identical to our particular species. Furthermore, we counted as a single species those that a previous author considered as distinct species, but which we regard as conspecific.

Fourteen prasinophyte, 27 acritarch, and one named chitinozoan species comprise the Arkona/Hungry Hollow/Widder assemblage; i.e. a total of 42 identified organic-walled microphytoplankton species. For counting purposes, we excluded from our assemblage or the comparison assemblages, the informal species designations (sp. or sp. A). For purposes of external comparison, we refer only to diverse, well-preserved and well-dated Middle Devonian assemblages. Those papers that include descriptions of only a few selected species, or lack acceptable stratigraphic control, are not incorporated in our analysis (although they are noted in the systematics section).

\section{North American assemblages}

Six microphytoplankton assemblages from North America are comparable to our Arkona/Hungry
Hollow/Widder palynoflora (Fig. 4). Legault (1973) described an assemblage from the Middle Devonian Hamilton Group (which includes the Arkona, Hungry Hollow and Widder formations) in southwestern Ontario. She recorded nine named species, together with a number of informally named species. Not unexpectedly, because of close geographic proximity and lithostratigraphic equivalence, there is a high existential degree of congruence (eight of nine named species, equalling $89 \%$ co-occurrence) between the two assemblages.

Playford (1977) described an Early to Middle Devonian organic-walled microphytoplankton assemblage from the Moose River Basin, Ontario. Counting only those named species that occurred in the Eifelian-Givetian upper two-thirds of the Kwataboahegan Formation, and the overlying Moose River, Murray Island and Williams Island formations, there are 22 species (59\%) shared with the section at Hungry Hollow. Although none of the taxa is restricted to North America, some have only a few extraNorth American occurrences. These include: Cymatiosphaera canadense (late Pragian-late Famennian; predominately Givetian), C. winderi (Emsian-Givetian; most commonly Givetian), Dictyotidium variatum (Lochkovian-Givetian; one doubtful Tournaisian occurrence in Xizang/Tibet), Polyedryxium fragosulum (Pragian-Frasnian; characteristically Givetian) and Baltisphaeridium distentum (Pragian-Famennian).

An extensive study of the Givetian Silica Formation, Ohio (Wicander and Wood 1981) yielded 37 of 48 species $(77 \%)$ co-occurring. Given the nearness of the two locations, and a Givetian age for both formations, close similarity between the two assemblages is hardly unexpected. A number of species known to be restricted stratigraphically (late Eifelian-Givetian) and geographically (North America) are shared with the palynoflora of this study; viz. Gorgonisphaeridium inflatum (late Eifelian-Givetian), Hapsidopalla chela (Eifelian-Givetian), Micrhystridium sp. A (Eifelian-Givetian), Uncinisphaera acantha (Givetian) and Villosacapsula compta (Givetian).

Wicander and Wright (1983) described a Middle Devonian acritarch/prasinophyte assemblage from the Columbus and Delaware limestones of Ohio. Despite poor preservation, 38 species proved identifiable, of which $28(74 \%)$ also occur in our Ontario assemblage. Wicander and Wright (1983) reported that the species from the limestone formations showed a high degree of similarity $(60 \%)$ to the younger Silica Formation (Wicander and Wood, 1981), and also to the Moose River Basin strata (Playford, 1977) and 
the Hamilton Group (Legault, 1973), both of which are in Ontario. Most of the species identified from the Columbus and Delaware limestones, are also components of the Silica Formation and the Arkona, Hungry Hollow and Widder formations, and require no citation here.

A $96 \%$ co-occurrence is evident between our Arkona/Hungry Hollow/Widder phytoplankton assemblage and that of the Middle Devonian (Givetian) Boyle Dolomite, Kentucky (Wood and Clendening, 1985). Of the 23 species reported from the Boyle Dolomite, only Lophosphaeridium ochthos Wicander and Wood, 1981 is unrepresented in our assemblage.

Wicander and Wood (1997) examined the organicwalled microphytoplankton from the upper Givetian Rapid Member of the Cedar Valley Formation, lowa. Although their emphasis was on the use of acritarchs/prasinophytes and chitinozoans for interpreting transgressive/regressive cycles, 33 well-preserved species were identified. Of these, 21 species $(64 \%)$ are shared with the Hungry Hollow sampled section.

As would be expected, very close similarity exists (59-96\% commonalty) between the Middle Devonian phytoplankton assemblage from the Hungry Hollow locale and coeval assemblages described from elsewhere in North America. Of shared occurrences are several stratigraphically long-ranging and palaeogeographically widespread forms such as Micrhystridium stellatum, Multiplicisphaeridium ramusculosum, Navifusa bacilla, Veryhachium europaeum, V. lairdii and V. trispinosum "complex." Also co-represented are many species that combine Devonian stratigraphic-limitation with extensive palaeogeographic distribution; e.g. Duvernaysphaera angelae, D. tenuicingulata, Muraticavea munifica, Polyedryxium embudum, $P$. pharaone, Daillyidium pentaster, Exochoderma arca, Stellinium comptum and S. micropolygonale. Lastly, five Middle Devonian species (all but one confined to the Givetian) occur only in North America: viz. Gorgonisphaeridium inflatum, Hapsidopalla chela, Micrhystridium sp. A, Uncinisphaera acantha and Villosacapsula compta.

\section{Extra-North American assemblages}

As within North America, the Arkona/Hungry Hollow/Widder palynoflora of this study can be compared with assemblages from elsewhere that have been well documented, sufficiently preserved, adequately illustrated and identified and stratigraphically constrained. Comparable South American assemblages include those reported by Barreda (1986), Ottone
(1996), Rubinstein $(1999,2000)$ and Amenábar et al. (2006) from Argentina. Other studies, such as those of Brito (e.g. 1965, 1966, 1967a, b, c, 1976) from Brazil, are not included here because either the stratigraphy was insufficiently defined or the assemblage was not comprehensively or adequately documented. The same applies to the papers by Pöthe de Baldis (1974, 1979; Paraguay), Pöthe de Baldis (1977; Uruguay) and, from Bolivia, Vavrdová et al. (1996) and di Pasquo (2007).

An assemblage of 33 named acritarch/prasinophyte species was documented by Barreda (1986) from subsurface strata, dated as transitional Givetian-Frasnian, of the Salta province, Argentina. Eighteen of the species she identified are represented in the Hungry Hollow sampled collection (55\% commonalty). Several species known hitherto only from North America (Baltisphaeridium distentum, Estiastra rhytidoa, Leiofusa pyrena, Muraticavea munifica and Polyedryxium ambitum) were subsequently reported from Argentina by Ottone (1996), Rubinstein (1999, 2000) and Amenábar et al. (2006), and from Bolivia by Wicander et al. (2011). In addition, the characteristic Middle-Late Devonian Gondwanan species Maranhites brasiliensis and Pterospermella pernambucensis were present, but Umbellasphaeridium deflandrei and U. saharicum were unrecorded.

Ottone (1996) described a palynologic assemblage from the Los Monos Formation (late Givetian-early Frasnian), Tarija Basin, Argentina, consisting of 51 acritarch/prasinophyte species (40 binomially named). Nineteen of the named Los Monos Formation species are also present in the Arkona/Hungry Hollow/Widder assemblage; i.e. a similarity of $48 \%$. It is also noteworthy that Maranhites mosesii and Umbellasphaeridium deflandrei - both components of Ottone's palynoflora have not been encountered in our samples.

Rubinstein (1999) recorded an assemblage of 14 acritarch/prasinophyte species (seven named binomially, three cf. designations and four in open nomenclature) from two palynofloras (Eifelian-Givetian and Givetian-Frasnian boundary beds respectively = Eifelian-early Frasnian herein) of the Punta Negra Formation in the San Juan Precordillera, Argentina. Her subsequent paper (Rubinstein 2000) revised the age of the Punta Negra Formation as transitional Givetian-Frasnian based on additional sampling and chitinozoan data. Although indifferently preserved, seven of the 10 named and cf.-designated microphytoplankton species also occur in our Ontario assemblage (70\%; albeit mostly longranging species). Additionally, Rubinstein recorded the Gondwanan form Maranhites cf. M. mosesii. 
Twenty-eight acritarch/prasinophyte species were reported by Amenábar et al. (2006) from the Chavela Member of the Chigua Formation, Rio Blanco Basin, San Juan Province, Argentina. Three palynologic assemblages were recovered from two locations with an overall proposed age of late Emsian through the Givetian/Frasnian boundary. Of the 16 binomially named species recorded, 11 co-occur in the Arkona/Hungry Hollow/Widder assemblage (69\%). These include such familiar North American taxa as Arkonites bilixus, Cymatiosphaera canadense, Estiastra rhytidoa, Exochoderma arca and Polyedryxium decorum. Amenábar et al. (2006) did not report any representatives of either Maranhites or Umbellasphaeridium.

Certain African locations have yielded well-preserved and diverse Devonian assemblages, several dated wholly, or partially, as Middle Devonian, based on chitinozoan and acritarch content. Anan-Yorke
(1974) described 21 binomially named species from three wells that penetrated Ghana's shelf and coastal region. Twelve of these species are shared with our assemblage (57\% co-occurrence). Most of the Ghanaian species are stratigraphically long ranging and geographically widespread; e.g. Micrhystridium stellatum, Multiplicisphaeridium ramusculosum and Veryhachium lairdii.

Jardiné (1972), Jardiné and Yapaudjian (1968) and Jardiné et al. $(1972,1974)$ described several assemblages from a series of Silurian-Devonian sections and wells in the Algerian Sahara of North Africa. The assemblage that includes Middle Devonian strata, and was reported by Jardiné and Yapaudjian (1968) from the Fort-Polignac Basin, is most representative of the lithostratigraphic units reported in the aforementioned papers. The Fort-Polignac assemblage contains 26 identified species, only eight of which are represented at Hungry Hollow. The shared species

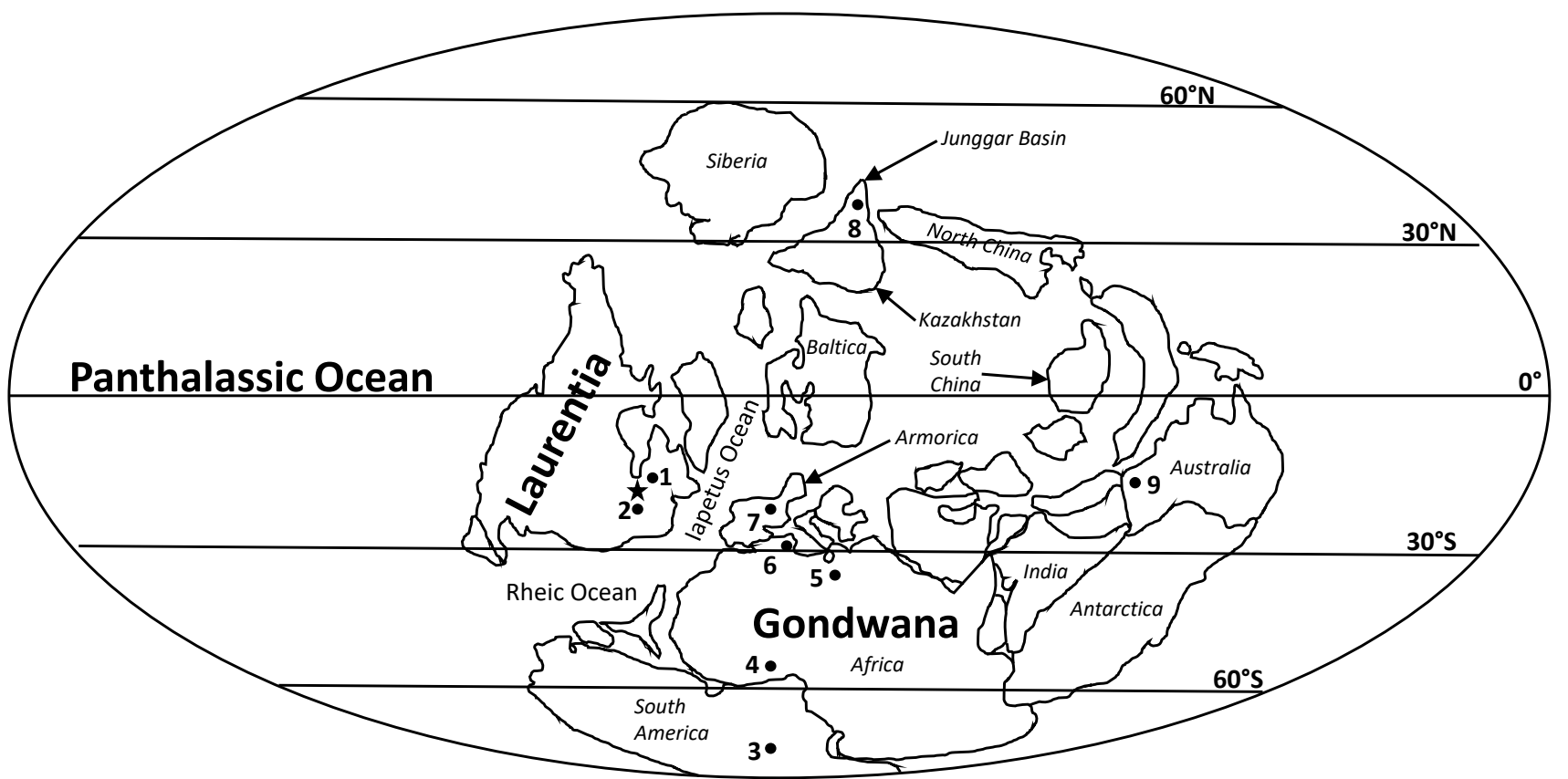

Figure 6. Palaeogeographic map for the Middle Devonian (modified from Scotese and McKerrow, 1990, p. 13, fig. 15 and Molyneux et al., 2013, p. 381, fig. 23.10). Solid star denotes the Hungry Hollow locality (present study). Key to numbered locations (generalized and shown as solid circles) and respective data sources: 1, Moose River Basin, Ontario (Playford, 1977); southwestern Ontario (Legault, 1973); 2, Ohio (Wicander and Wood, 1981; Wicander and Wright, 1983); Kentucky (Wood and Clendening, 1985); lowa (Wicander and Wood, 1997); 3, Argentina (Barreda, 1986; Ottone, 1996; Rubinstein, 1999; Amenábar et al., 2006); 4, Ghana (Anan-Yorke, 1974); 5, Libya (Moreau-Benoit, 1984); 6, Algerian Sahara (Jardiné and Yapaudjian, 1968; Jardiné, 1972; Jardiné et al., 1972, 1974); 7, Armorica (Turnau and Racki, 1999); 8, eastern Junggar Basin, Kazakhstan (Zhu Huaicheng et al., 2008); 9, Canning Basin, Western Australia (Colbath, 1990).

Figura 6. Mapa paleogeográfico para el Devónico Medio (modificado de Scotese and McKerrow, 1990, p. 13, fig. 15 y Molyneux et al., 2013, p. 381, fig. 23.10). La estrella indica la localidad de Hungry Hollow (estudio actual). Clave de localidades (señaladas por círculos) y fuentes de datos: 1, Cuenca del Río Moose, Ontario (Playford, 1977); suroeste de Ontario (Legault, 1973); 2, Ohio (Wicander and Wood, 1981; Wicander and Wright, 1983); Kentucky (Wood and Clendening, 1985); lowa (Wicander and Wood, 1997); 3, Argentina (Barreda, 1986; Ottone, 1996; Rubinstein, 1999; Amenábar et al., 2006); 4, Ghana (Anan-Yorke, 1974); 5, Libia (Moreau-Benoit, 1984); 6, Sahara argelino (Jardiné and Yapaudjian, 1968; Jardiné, 1972; Jardiné et al., 1972, 1974); 7, Armórica, Francia (Turnau and Racki, 1999); 8, Este de la Cuenca de Junggar, Kazakhstan (Zhu Huaicheng et al., 2008); 9, Cuenca de Canning, Oeste de Australia (Colbath, 1990). 
Wicander, R. and Playford, G., 2017. Organic-walled microphytoplankton assemblage... Boletín Geológico y Minero, 128 (4): $839-883$

(31\% from two locations), like those reported by Anan-Yorke (1974), are stratigraphically long ranging and widely distributed palaeogeographically.

Core samples from three wells in western Libya (Moreau-Benoit 1984) yielded 37 species, 17 of which are found at Hungry Hollow (46\%), including such low-latitude, typically northern hemisphere, Middle Devonian species as Cymatiosphaera canadense, $C$. winderi, Polyedryxium decorum and P. fragosulum. These were reportedly associated with a number of stratigraphically long ranging and widely distributed taxa, all of which have previously been mentioned. Additionally represented, are the characteristic Gondwana species Maranhites brasiliensis, Umbellasphaeridium deflandrei and U. saharicum, which do not appear in Laurentia until the Late Devonian.

A number of papers have been published that include Middle Devonian strata in Europe. Except for a Givetian assemblage described byTurnau and Racki (1999) from the Holy Cross Mountains in central Poland, none of the published literature from the European continent contains sufficiently diverse assemblages to warrant discussion in an extra-North American comparative context. Turnau and Racki's acritarch/prasinophyte assemblage contains 23 named species, 12 of which also occur in the Arkona/Hungry Hollow/Widder assemblage (52\% commonalty). Moreover, Arkonites bilixus and Daillydium pentaster are also found at this location.

Colbath (1990) documented a Givetian-Frasnian organic-walled microphytoplankton flora from the Canning Basin, Western Australia. This assemblage is composed of 66 named species, 34 of which were newly proposed and appear to be endemic to the region. Only eight species are common to the Arkona/Hungry Hill/Widder assemblage (12\% shared taxa); all of these, with the exception of Daillydium pentaster, are palaeogeographically and stratigraphically widespread and long ranging.

The final assemblage meriting discussion here is from the Middle Devonian (Eifelian) Ulusubasite Formation, eastern Junggar Basin, Xinjiang, China (Zhu Huaicheng et al. 2008). As noted by those authors, Devonian palynologic studies from China have only been reported from scattered localities. Several reports are from the Upper Devonian, but prior to 2008, there were no published studies for the Middle Devonian. Although the Ulusubasite preservation is less than ideal, a miospore and organic-walled microphytoplankton palynoflora was recognized, consisting of 19 acritarch/prasinophyte species, 13 which were binomially named. There are 10 species in common with our Ontario assemblage, a similarity factor of $77 \%$, and all are stratigraphically long-ranging and cosmopolitan. Thus, the Junggar Basin phytoplankton assemblage evinces a marine connection between Laurentia, Baltica, Kazakhstan (Junggar Basin) and Gondwana.

\section{Palaeogeographic implications}

During the Middle Devonian, Laurentia occupied a low-latitude region, extending from ca $30^{\circ} \mathrm{N}$ to $30^{\circ} \mathrm{S}$, and separated narrowly from Baltica on the east by progressive closure of the lapetus Ocean (Fig. 6). By the end of the Devonian, Baltica and Laurentia effectively became a single landmass (Laurasia). During the Middle and Late Devonian, Laurentia (Laurasia) remained distinct from Gondwana by the intervening Rheic Ocean, which, like the lapetus Ocean, was also decreasing in size, thus bringing the two continents in closer proximity (Fig. 6).

In terms of Devonian microphytoplankton, the Late Devonian has received the most attention, although a sizeable literature exists for the Middle Devonian, as discussed in the previous section. As mentioned elsewhere, a number of early studies involved poorly preserved or inadequately illustrated assemblages that lacked stratigraphic documentation and/or chronologic calibration, thus limiting their applicability to stratal correlation, comparison of palynologic assemblages and palaeogeographic synthesis. Furthermore, the palaeogeographic coverage of microphytoplankton assemblages for the Middle Devonian is uneven (Molyneux et al. 2013).

Despite these limitations, analysis of those well-preserved and stratigraphically constrained Middle Devonian acritarch/prasinophyte assemblages previously discussed connotes a significant degree of cosmopolitanism. Palaeogeograpically widespread taxa include Arkonites bilixus, Cymatiosphaera cornifera, Duvernaysphaera angelae, $D$. tenuicingulata, Polyedryxium embudum, P. pharaone, Daillydium pentaster, Exochoderma arca, Micrhystridium stellatum, Multiplicisphaeridium ramusculosum, Navifusa baciIla, Ozotobrachion furcillatus, Palacanthus ledanoisii, Stellinium comptum, S. micropolygonale, Tunisphaeridium tentaculaferum, Tyligmasoma alarga$d a$, Veryhachium europaeum, V. lairdii, V. polyaster, $V$. trispinosum "complex" and Villosacapsula rosendae.

A number of distinctive and commonly occurring species are seemingly restricted to Laurentia such as: Eisenackidium appendiculum, Gorgonisphaeridium inflatum, Hapsidopalla chela, Uncinisphaera acantha and Villosacapsula compta.

The remainder of the Arkona/Hungry Hollow/Widder phytoplankton assemblage contains 
taxa found predominately in Laurentia, but also reported from several extra-Laurentian localities. With few exceptions, the majority of species recorded from North America show dispersal to other locations during the Middle Devonian. However, certain species were endemic to high-latitude areas of Gondwana, in association with many low- to mid-latitude species. These Gondwanan high-latitude taxa include Maranhites brasiliensis, M. mosesii, Pterospermella pernambucensis, Umbellasphaeridium deflandrei and $U$. saharicum although some of these species may be misidentified (Alain Le Hérissé, personal communication).

Wood (1984) reviewed the palaeobiogeographic dispersal of Umbellasphaeridium deflandrei, U. saharicum and the "Maranhites brasiliensis complex" (the latter informally linking $M$. brasiliensis with $M$. mosesii). He noted that the first appearance in North America of these three taxonomic categories did not occur until the Late Devonian. His conclusion was that the post-Middle Devonian dispersal of these species from the high latitudes of Gondwana to the mid- to low-latitudes closely paralleled a seaway connection inferred previously from the distribution of coral and goniatite taxa. The distribution of Middle Devonian acritarchs/prasinophytes discussed in this paper, supports that scenario.

In summary, the Arkona/Hungry Hollow/Widder organic-walled microphytoplankton represent a lowto mid-palaeolatitude, warm-water, marine assemblage consisting of both stratigraphically short- and long-ranging, cosmopolitan taxa. Although many of the widespread species occur in the mid- to highpalaeolatitudes of Gondwana, a Middle Devonian endemic population of phytoplankton existed in the Gondwanan high latitudes, and did not migrate to Laurasia until the Late Devonian.

\section{Conclusions}

A diverse and well-preserved acritarch/prasinophyte assemblage is profusely represented in a 13.3-m exposure of the Middle Devonian (Givetian) Arkona, Hungry Hollow and Widder formations at Hungry Hollow in southwestern Ontario, Canada.

The palynoflora comprises 49 acritarch, prasinophyte and one chitinozoan species, 42 of which have previously been named, and seven left in open nomenclature. Additionally, other chitinozoans, scolecodonts and miospores also occur, albeit in lesser diversity and abundance, and are not identified taxonomically.

The assemblage's adduced Middle Devonian
(Givetian) age is based on the vertical ranges of certain acritarch and prasinophyte species as reported from biostratigraphically constrained assemblages in North America and elsewhere; and accords with the dating of associated marine invertebrate faunas.

The palynofloral composition signifies deposition in a well-oxygenated, marine, offshore shelf environment, with periodic regressions promoting the development of reef-type environments.

The Arkona/Hungry Hollow/Widder organic-walled microphytoplankton assemblage reflects a high degree of cosmopolitanism, as well as confirming an endemic high-latitude Gondwanan contribution, many species of which did not migrate into the lowmiddle-latitudes until the Late Devonian.

\section{Acknowledgements}

This paper is part of the authors' ongoing studies of Devonian organic-walled microphytoplankton. It was initiated by the first author at the Department of Earth and Atmospheric Sciences, Central Michigan University, and completed in collaboration with the second author at the School of Earth and Environmental Sciences, The University of Queensland (UQ) whilst Reed Wicander was there on a research appointment.

We thank Professor Paulo Vasconcelos for hosting Reed Wicander, as well as staff members Tracy Paroz and Indira Jones for their assistance during the course of this project. Alain Le Hérissé (Brest, France) and Merrell Miller (Tulsa, Oklahoma) provided insightful comments and suggestions that improved this paper. Jeremy Conner (Columbus, Ohio) ably draughted Figures 1, 2 and 4-6.

\section{References}

Al-Ameri, T.K. 1983. Acid-resistant microfossils used in the determination of Palaeozoic palaeoenvironments in Libya. Palaeogeography, Palaeoclimatology, Palaeoecology, 44, 103-116.

Amenábar, C.R. 2009. Middle Devonian microfloras from the Chigua Formation, Precordillera region, northwestern Argentina. In: Königshof, P. (ed.), Devonian Change: Case Studies in Palaeogeography and Palaeoecology. Geological Society of London, Special Publications, 314, 177-192.

Amenábar, C.R., di Pasquo, M., Carrizo, H.A. and Azcuy, C.L. 2006. Palynology of the Chigua (Devonian) and Malimán (Carboniferous) formations in the Volcán Range, San Juan Province, Argentina. Part I. Paleomicroplankton and acavate smooth and ornamented spores. Ameghiniana, 43, 339-375. 
Anan-Yorke, R. 1974. Devonian Chitinozoa and acritarchs from exploratory oil wells on the shelf and coastal region of Ghana, West Africa. Ghana Geological Survey, Bulletin, 37, 1-216.

Armstrong, D.K. and Carter, T.R. 2006. An updated guide to the subsurface Paleozoic stratigraphy of southern Ontario. Ontario Geological Survey, Open File Report, 6191, 1-214.

Audretsch, A.P. 1967. Middle Devonian microflora from the Great Slave Lake area, Northwest Territories, Canada. In: Oswald, D.H. (ed.), Proceedings of the International Symposium on the Devonian System, Calgary (1967), volume 2. Alberta Society of Petroleum Geologists, 837847.

Bain, A. and Doubinger, J. 1965. Etude d'un microplancton (Acritarches) du Dévonien supérieur des Ardennes. Bulletin du Service de la Carte Géologique d'Alsace et de Lorraine, 18, 15-30.

Barreda, V.D. 1986. Acritarcos givetiano-frasnianos de la Cuenca del Noroeste, provincia de Salta, Argentina. Revista Española de Micropaleontología, 18, 229-245.

Bartholomew, A.J. and Brett, C.E. 2007. Correlation of Middle Devonian Hamilton Group-equivalent strata in east-central North America: implications for eustasy, tectonics and faunal provinciality. In: Becker, R.T. and Kirchgasser, W.T. (eds.), Devonian Events and Correlations. Geological Society of London, Special Publications, 278, 105-132.

Baschnagel, R.A. 1942. Some microfossils from the Onondaga Chert of central New York. Buffalo Society of Natural Science, Bulletin, 17, 1-8.

Boneham, R.F. 1967a. Hamilton (Middle Devonian) Chitinozoa from Rock Glen, Arkona, Ontario. American Midland Naturalist, 78, 121-125.

Boneham, R.F. 1967b. Devonian Tasmanites from Michigan, Ontario, and northern Ohio. Papers of the Michigan Academy of Science, Arts, and Letters, 52, 163-173.

Brett, C.E., Baird, G.C., Bartholomew, A.J., DeSantis, M.K. and Ver Straeten, C.A. 2011. Sequence stratigraphy and a revised sea-level curve for the Middle Devonian of eastern North America. Palaeogeography, Palaeoclimatology, Palaeoecology, 304, 21-53.

Brito, I.M. 1965. Nota prèva sôbre os microfósseis Devonianos de Pernambuco. Universidade da Bahia Escola de Geologia, 3, 1-8.

Brito, I.M. 1966. Contribuição ao conhecimento dos Microfósseis Silurianos e Devonianos da Bacia do Maranhão. II. Acritarcha Polygonomorphitae e Pteromorphitae. Publicação Sociedade Brasileira Geologica Nucleo Rio de Janeiro, 1, 78-79.

Brito, I.M. 1967a. Os Acritarcha. Brasileira Divisão de Geologia e Mineralogia, Notas Preliminares e Estududos, 138, 1-21.

Brito, I.M. 1967b. Silurian and Devonian Acritarcha from Maranhão Basin, Brazil. Micropaleontology, 13, 473-482.

Brito, I.M. 1967c. Nôvo Subgrupo de Acritarcha do Devoniano do Maranhão. Anais da Academia Brasileira de Ciências, 39, 163-166.

Brito, I.M. 1969. Un nouveau sous-groupe d'acritarche. Boletim de Geologia, Universidade Federal do Rio de Janeiro, Instituto de Geociências, 4, 11-13.
Brito, I.M. 1976. Contribuição ao conhecimento dos Microfósseis Devonianos de Pernambuco. III-Alguns Acritarcha Comuns aos do Devoniano do Saara. Anais de Academia Brasileira de Ciências, 48, 747-756.

Christensen, T. 1962. Botanik, Bind 2. Systematisk botanic. Nr. 2. Alger. Munksgaard, København, 178 pp.

Colbath, G.K. 1980. Abundance fluctuations in Upper Ordovician organic-walled microplankton from Indiana. Micropaleontology, 26, 97-102.

Colbath, G.K. 1990. Devonian (Givetian-Frasnian) organicwalled phytoplankton from the Limestone Billy Hills reef complex, Canning Basin, Western Australia. Palaeontographica, Abteilung B, 217, 87-145.

Combaz, A., Lange, F.W. and Pansart, J. 1967. Les "Leiofusidae" Eisenack, 1938. Review of Palaeobotany and Palynology, 1, 291-307.

Cramer, F.H. 1963. Nota provisional sobre la presencia de microplankton y esporomorfas en las rocas sedimentarias de Devónico Inferior en las Montañas Cantábricas. Estudios Geológicos, 19, 215-218.

Cramer, F.H. 1964. Microplankton from three Paleozoic formations in the province of Leon, NW-Spain. Leidse Geologische Mededelingen, 30, 253-361.

Cramer, F.H. 1966. Hoegispheres and other microfossils incertae sedis of the San Pedro Formation (Siluro-Devonian boundary) near Valporquero, Leon, NW Spain. Notas y Comunicaciones del Instituto Geológico y Minero de España, 86, 75-94.

Cramer, F.H. 1967. Palynology of Silurian and Devonian rocks in northwest Spain. Boletín del Instituto Geológico y Minero de España, 77, 223-286.

Cramer, F.H. 1968. Palynologic microfossils of the Middle Silurian Maplewood Shale in New York. Revue de Micropaléontologie, 11, 61-70.

Cramer, F.H. 1971. Distribution of selected Silurian acritarchs. Revista Española de Micropaleontología, número extraordinario, 1-203. [Imprinted 1970, published 1971 according to Loeblich and Tappan, 1976, p. 302].

Cramer, F.H. and Díez, M. del C.R. 1968. Consideraciones taxonómicas sobre las acritarcas del Silúrico Medio y Superior del Norte de España. Boletín del Instituto Geológico y Minero de España, 79, 541-574.

Cramer, F.H. and Díez, M. del C.R. 1972. North American Silurian palynofacies and their spatial arrangement: acritarchs. Palaeontographica, Abteilung B, 138, 107-180.

Cramer, F.H. and Díez, M. del C.R. 1976. Acritarchs from the La Vid Shales (Emsian to Lower Couvinian) at Colle, Léon, Spain. Palaeontographica, Abteilung B, 158, 72103.

Cunha, T. and Oliveira, J.T. 1989. Upper Devonian palynomorphs from the Represa and Phylite-Quartzite Formation, Mina de São Domingos region, southwest Portugal. Tectonostratigraphic implications. Bulletin de la Société belge de géologie, 98, 295-309.

Deflandre, G. 1937. Microfossiles des silex crétacés. Deuxième partie. Flagellés incertae sedis. Hystrichosphaeridés. Sarcodinés. Organismes divers. Annales de Paléontologie, 26, 51-103.

Deflandre, G. 1942. Sur les Hystrichospherès des calcaires siluriens de la Montagne Noire. Comptes rendus des séances de l'Académie des sciences, 215, 475-476. 
Deflandre, G. 1945. Microfossiles des calcaires siluriens de la Montagne Noire. Annales de Paléontologie, 31, 39-75.

Deflandre, G. 1946. Fichier micropaléontologique - série 8. Hystrichosphaeridés III. Espèces du Primaire Archives originales. Centre de documentation; Centre national de la recherché scientifique, France, 257, I-V, fiches 10961185.

Deflandre, G. 1954. Systématique des Hystrichosphaeridés: sur I'acception du genre Cymatiosphaera O. Wetzel. Compte rendu sommaire et bulletin de la Société géologique de France, 1954/12, 257-258.

Deflandre, G. 1968. Sur I'existence, dans le Précambrien, d'acritarches du type Acanthomorphitae, Eomicrhystridium nov. gen. Typification du genre Palaeocryptidium Defl. 1955. Comptes rendus des séances de l'Académie des sciences, sér. D, 266, 23852389.

Deunff, J. 1954. Sur un microplancton du Dévonien du Canada recélant des types nouveaux d'Hystrichosphaerides. Comptes rendus des séances de l'Académie des sciences, 239, 1064-1066.

Deunff, J. 1955. Un microplancton fossile Dévonien à Hystrichosphères du Continent Nord-Américain. Bulletin de Microscopie Appliquée, sér. 2, 5, 138-149.

Deunff, J. 1956. Progrès récents de nos connaissances sur les microplanctons fossils à hystrichosphères des mers primaires. Grana Palynologica, n.s. 1, 2, 79-84.

Deunff, J. 1957. Micro-organismes nouveaux (Hystrichosphères) du Dévonien de l'Amérique du Nord. Société géologique et mineralogique de Bretagne, Bulletin, 2, 5-14.

Deunff, J. 1959. Microorganismes planctoniques du Primarie Armoricain. I. Ordoviciens du Veryhac'h (Presqu'ile de Crozon). Bulletin de la Société Géologie Minéralogie, Bretagne, new serie, 14, 1-41. [Imprinted 1958, issued 1959 according to Loeblich and Tappan, 1976, p. 306].

Deunff, J. 1961. Quelques précisions concernant les Hystrichosphaeridées du Dévonien du Canada. Compte rendu sommaire des séances de la Société géologique de France, 8, 216-218.

Deunff, J. 1964. Le genre Duvernaysphaera Staplin. Grana Palynologica, 5, 210-215.

Deunff, J. 1966a. Recherches sur les microplanctons du Dévonien (Acritarches et Dinophyceae). Thèse, Université Rennes, France, 168 pp.

Deunff, J. 1966b. Acritarches du Dévonien du Tunisie. Compte rendu sommaire des séances de la Société géologique de France, 1, 22-24.

Deunff, J. 1967. Présence d'Acritarches dans une série dévonienne du lac Huron (Canada). Compte rendu sommaire des séances de la Société géologique de France, 6, 258260.

Deunff, J. 1971. Le genre Polyedryxium Deunff. Révision et observations. In: Jardiné, S. (ed.), Microfossiles Organiques du Paléozoïque, fasc. 3. Acritarches. Commission Internationale de Microflore du Paléozoïque, Editions du Centre national de las recherché scientifique, Paris, 7-48.

Deunff, J. 1980. Le paléoplancton des Grès de Landévennec
(Gedinnien de la rade de Brest - Finistère) étude biostratigraphique. Geobios, 13, 483-539.

Deunff, J. 1981. Observations preliminaries sur le paléophytoplancton de la coupe de Caffiers (Givétien-Frasnien du Boulonnais, France). Annales de la Société Géologique du Nord, 100, 65-71.

Deunff, J. and Evitt, W.R. 1968. Tunisphaeridium, a new acritarch genus from the Silurian and Devonian. Stanford University Publications, Geological Sciences, 12, 1-13.

di Pasquo, M. 2007. Asociaciones palinológicas en las formaciones Los Monos (Devónico) e Itacua (Carbonífero Inferior) en Balapuca (Cuenca Tarija), sur de Bolivia. Parte 1. Formación Los Monos. Revista Geológica de Chile, 34, 97-137.

Dorning, K.J. 1981. Silurian acritarch distribution in the Ludlovian shelf sea of South Wales and the Welsh Borderland. In: Neal, R.G. and Brasier, M.D. (eds.), Microfossils from Recent and Fossil Shelf Seas. Ellis Horwood Ltd., Chichester, England, 31-36.

Downie, C. 1959. Hystrichospheres from the Silurian Wenlock Shale of England. Palaeontology, 2, 56-71.

Downie, C. 1963. "Hystrichospheres" (acritarchs) and spores of the Wenlock Shales (Silurian) of Wenlock, England. Palaeontology, 6, 625-652.

Driscoll, E.G., Hall, D.D. and Nussman, D.G. 1965. Morphology and paleoecology of the brachiopod Leiorhynchus kelloggi Hall, Middle Devonian, Ohio, Michigan, Ontario. Journal of Paleontology, 38, 916-935. Eisenack, A. 1931. Neue Microfossilien des baltischen Silurs. I. Paläontologische Zeitschrift, 13, 74-118.

Eisenack, A. 1934. Neue Mikrofossilien des baltischen Silurs III und neue Mikrofossilien des böhmischen Silurs I. Paläontologische Zeitschrift, 16, 52-76.

Eisenack, A. 1938. Hystrichosphäerideen und verwandte Formen im baltischen Silur. Zeitschrift für Geschiebeforschung und Flachlandsgeologie, 14, 1-30.

Eisenack, A. 1955. Chitinozoen, Hystrichosphären und andere mikrofossilien aus dem Beyrichia-Kalk. Senckenbergiana Lethaea, 36, 157-188.

Eisenack, A. 1958. Mikroplankton aus dem norddeutschen Apt nebst einigen Bemerkungen über fossile Dinoflagellaten. Neues Jahrbuch für Geologie und Paläontologie, Abhandlungen, 106, 383-422.

Eisenack, A. 1959. Neotypen baltischer SilurHystrichosphären und neue Arten. Palaeontographica, Abteilung A, 112, 193-211.

Eisenack, A. 1965. Die Mikrofauna der Osteekalke. 1. Chitinozoen, Hystrichosphären. Neues Jahrbuch für Geologie und Paläontologie, Abhandlungen, 123, 115148.

Eisenack, A. 1969. Zur Systematik einiger paläozoischer Hystrichosphären (Acritarcha) des baltischen Gebietes. Neues Jahrbuch für Geologie und Paläontologie, Abhandlungen, 133, 245-266.

Eisenack, A. 1972. Beiträge zur Chitinozoen-Forschung. Palaeontographica, Abteilung A, 140, 117-130.

Eisenack, A. 1976. Mikrofossilien aus dem Vaginatenkalk von Hälludden, Öland. Palaeontographica, Abteilung A, 154, 181-203.

Eisenack, A., Cramer, F.H. and Díez, M. del C.R. 1973. Katalog 
Wicander, R. and Playford, G., 2017. Organic-walled microphytoplankton assemblage... Boletín Geológico y Minero, 128 (4): $839-883$

der fossilen Dinoflagellaten, Hystrichosphären und verwandten Mikrofossilien. Band III Acritarcha 1. Teil. E. Schweizerbart'sche Verlagsbuchhandlung, Stuttgart, Germany, 1104 pp.

Erkmen, U. and Bozdogan, N. 1979. Acritarchs from the Dadas Formation in southeast Turkey. Géobios, 12, 445449.

Evitt, W.R. 1961. Observations on the morphology of fossil dinoflagellates. Micropaleontology, 7, 385-420.

Evitt, W.R. 1963. A discussion and proposals concerning fossil dinoflagellates, hystrichospheres, and acritarchs, I, II. Proceedings of the United States National Academy of Sciences, 49, 158-164, 298-302.

Fatka, O. and Brocke, R. 2008. Morphological variability and method of opening of the Devonian acritarch Navifusa bacilla (Deunff, 1955) Playford, 1977. Review of Palaeobotany and Palynology, 148, 108-123.

Gao Lianda. 1986. Late Devonian and Early Carboniferous acritarchs from Nyalam County, Xizang (Tibet), China. Review of Palaeobotany and Palynology, 47, 17-30.

Ghavidel-syooki, M. 1994. Upper Devonian acritarchs and miospores from the Geirud Formation in central Alborz Range, northern Iran. Journal of Sciences, Islamic Republic of Iran, 5, 103-122.

Ghavidel-syooki, M. 1995. Palynostratigraphy and palaeogeography of a Palaeozoic sequence in the Hassanakdar area, central Alborz Range, northern Iran. Review of Palaeobotany and Palynology, 86, 91-109.

González, F., Playford, G. and Moreno, C. 2005. Upper Devonian biostratigraphy of the Iberian Pyrite Belt, southwest Spain. Part one: miospores. Palaeontographica, Abteilung B, 273, 1-51.

Górka, H. 1969. Microorganismes de l'Ordovicien de Pologne. Palaeontologia Polonica, 22, 1-102.

Górka, H. 1974. Les acritarches de concretions calcaires du Famennien supérieur de Lagów (Monts de Sainte Croix, Pologne). Acta Palaeontologica Polonica, 19, 225-250.

Gray, J. and Boucot, A.J. 1972. Palynologic evidence bearing on the Ordovician-Silurian paraconformity in Ohio. Geological Society of America, Bulletin, 83, 1299-1314.

Hashemi, H. and Playford, G. 1998. Upper Devonian palynomorphs of the Shishtu Formation, Central Iran Basin, east-central Iran. Palaeontographica, Abteilung B, 246, 115-212.

Heal, S. and Clayton, G. 2008. The palynology of the Hannibal Shale (Mississippian) of northeastern Missouri, U.S.A. and correlation with Western Europe. Palynology, 32, 27-37.

Huysken, K.T., Wicander, R. and Ettensohn, F.R. 1992. Palynology and biostratigraphy of selected Middle and Upper Devonian black-shale sections in Kentucky. Michigan Academician, 24, 355-368.

Jacobson, S.R. 1979. Acritarchs as paleoenvironmental indicators in Middle and Upper Ordovician rocks from Kentucky, Ohio and New York. Journal of Paleontology, 53, 1197-1212.

Jansonius, J. 1962. Palynology of Permian and Triassic sediments, Peace River area, western Canada. Palaeontographica, Abteilung B, 110, 35-98.

Jansonius, J. 1964. Morphology and classification of some
Chitinozoa. Bulletin of Canadian Petroleum Geology, 12, 901-918.

Jardiné, S. 1972. Microplancton (Acritarches) et limites stratigraphiques du Silurien terminal au Dévonien supérieur. Comptes rendus, Septième Congres International de Stratigraphie et de Géologie du Carbonifère, Krefeld, August 1971, 1, 313-323.

Jardiné, S. and Yapaudjian, L. 1968. Lithostratigraphie et palynology du Dévonien-Gothlandien gréseux du Bassin de Polignac (Sahara). Revue de I'Institut Français du Pétrole, 23, 439-469.

Jardiné, S., Combaz, A., Magloire, L., Peniguel, G. and Vachey, G. 1972. Acritarches du Silurien terminal et du Dévonien du Sahara Algérien. Comptes rendus, Septième Congres International de Stratigraphie et de Géologie du Carbonifère, Krefeld, August 1971, 1, 295-311.

Jardiné, S., Combaz, A., Magloire, L., Peniguel, G. and Vachey, G. 1974. Distribution stratigraphique des Acritarches dans le Paléozoïque du Sahara Algérien. Review of Palaeobotany and Palynology, 18, 99-129.

Johnson, M.D., Armstrong, D.K., Sanford, B.V., Telford, P.G. and Rutka, M.A. 1992. Paleozoic and Mesozoic geology of Ontario. In: Thurston, P.C., Williams, H.R., Sutcliffe, R.H. and Stott, G.M. (eds.), Geology of Ontario. Ontario Geological Survey Special Volume 4, Part 2, 907-1008.

Jux, U. 1975. Phytoplankton aus dem mittleren Oberdevon (Nehden-Stuff) des südwestlichen Bergischen Landes (Rheinisches Schiefergebirge). Palaeontographica, Abteilung B, 149, 113-138.

Kimpe, W.F.M., Bless, M.J.M., Bouckaert, J., Conil, R., Grossens, E., Meessen, J.P.M.T., Poty, E., Streel, M., Thorez, J. and Vanguestaine, M. 1978. Paleozoic deposits east of the Brabant Massif in Belgium and the Netherlands. Mededelingen Rijks Geologische Dienst, 30, 37-103.

Kimyai, A. 1983. Paleozoic microphytoplankton from South America. Revista Española de Micropaleontología, 15, 415-426.

Landing, E. and Brett, C.E. 1987. Trace fossils and regional significance of a Middle Devonian (Givetian) disconformity in southwestern Ontario. Journal of Paleontology, 61, 205-230.

Lanzoni, E. and Magloire, L. 1969. Associations palynologiques et leurs applications stratigraphiques dans le Dévonien supérieur et Carbonifère inférieur du Grand Erg occidental (Sahara Algérien). Revue de I'Institut Français du Pétrole, 24, 441-469.

Legault, J.A. 1973. Chitinozoa and Acritarcha of the Hamilton Formation (Middle Devonian), southwestern Ontario. Geological Survey of Canada, Bulletin, 221, 1-103.

Le Hérissé, A. 1989. Acritarches et kystes d'algues Prasinophycés du Silurien de Gotland, (Suède). Palaeontographia Italica, 76, 57-298.

Le Hérissé, A. and Deunff, J. 1988. Acritarches et prasinophycees (Givétien supérieur-Frasnian moyen) de Ferques (Boulonnais-France). In: Brice, D. (ed.), Le Dévonien de Ferques, Bas-Boulonnais (N. France). Biostratigraphie du Paleozoïque. Université de Bretagne Occidentales, 7, 103-152.

Le Hérissé, A., Servais, T. and Wicander, R. 2000. Devonian 
acritarchs and related forms. Courier Forschungsinsitut Senckenberg, 220, 195-205.

Li Jun, Servais, T., Yan Kui and Zhu Huaicheng. 2004. A nearshore-offshore trend in acritarch distribution from the Early-Middle Ordovician of the Yangtze Platform, South China. Review of Palaeobotany and Palynology, 130, 141-161.

Lister, T.R. 1970. A monograph of the acritarchs and Chitinozoa from the Wenlock and Ludlow series of the Ludlow and Millichope areas, Shropshire, Part 1. Palaeontographical Society (London) Monograph, 124, 1-100.

Loeblich, A.R., Jr. 1970. Morphology, ultrastructure and distribution of Paleozoic acritarchs. North American Paleontological Convention, Chicago (1969), Proceedings, Part G, 705-788.

Loeblich, A.R., Jr. and Drugg, W.S. 1968. New acritarchs from the Early Devonian (late Gedinnian) Haragan Formation of Oklahoma, U.S.A. Tulane Studies in Geology, 6, 129-137.

Loeblich, A.R., Jr. and Tappan, H. 1976. Some new and revised organic-walled phytoplankton microssil genera. Journal of Paleontology, 50, 301-308.

Loeblich, A.R., Jr. and Wicander, E.R. 1976. Organic-walled microplankton from the Lower Devonian late Gedinnian Haragan and Bois d'Arc Formations of Oklahoma, U.S.A. Part 1. Palaeontographica, Abteilung B, 159, 1-39.

Lu Li-chang and Wicander, R. 1988. Upper Devonian acritarchs and spores from the Hongguleleng Formation, Hefeng district in Xinjiang, China. Revista Española de Micropaleontología, 20, 109-148.

Martin, F. 1967. Les Acritarches du parc de Neuvile-sous-Huy (Silurien belge). Bulletin de la Sociéte belge de géologie, de paléontologie et d'hydrologie, 74, 306-335.

Martin, F. 1981. Acritarches du Famennien inférieur à Villerssur-Lesse (Belgique). Bulletin de I'Institut royal des Sciences naturelles de Belgique, Sciences de la Terre, no. 2, 52, 1-49.

Martin, F. 1985. Acritarches du Frasnien supérieur et du Famennien inférieur du bord méridional du Bassin de Dinant (Ardenne belge). Bulletin de I'Institute royal des Sciences naturelles de Belgique, Sciences de la Terre, no. 2, 55, 1-57.

Massa, D. and Moreau-Benoit, A. 1985. Apport de nouvelles donnés palynologiques a la biostratigraphie et a la paléogéographie du Dévonien de Libye (Sud du Bassin de Rhadamès). Sciences Geologiques, Bulletin, 38, 5-18.

McNeill, J., Barrie, F.R., Buck, W.R., Demoulin, V., Greuter, W., Hawksworth, D.L., Herendeen, P.S., Knapp, S., Marhold, K., Prado, J., Prud'homme Van Reine, W.F., Smith, G.F., Wiersema, J.H. andTurland, N.J. (eds.). 2012. International Code of Nomenclature for algae, fungi, and plants (ICN; Melbourne Code) adopted by the Eighteenth International Botanical Congress Melbourne, Australia, July 2011. Regnum Vegetabile, 154, Koeltz Scientific Books, Koenigstein, Germany, 1-240.

McNestry, A. 1988. The palynostratigraphy of two uppermost Devonian-Lower Carboniferous borehole sections in South Wales. Review of Palaeobotany and Palynology, 56, 69-87.
Mitchell, S.W. 1967. Stratigraphy of the Silica Formation of Ohio and the Hungry Hollow Formation of Ontario, with paleogeographic interpretations. Papers of the Michigan Academy of Science, Arts, and Letters, 52, 175-196.

Moczydłowska, M. 1998. Cambrian acritarchs from the Upper Silesia, Poland - biochronology and tectonic implications. Fossils and Strata, 46, 1-121.

Molyneux, S.G., Manger, W.L. and Owens, B. 1984. Preliminary account of Late Devonian palynomorph assemblages from the Bedford Shale and Berea Sandstone formations of central Ohio, U.S.A. Journal of Micropalaeontology, 3, 41-51.

Molyneux, S.G., Delabroye, A., Wicander, R. and Servais, T. 2013. Biogeography of early to mid Palaeozoic (Cambrian-Devonian) marine phytoplankton. In: Harper, D.A.T. and Servais, T. (eds.), Early Palaeozoic Biogeography and Palaeogeography, Chapter 23. Geological Society, London, Memoirs, 38, 365-397.

Moreau-Benoit, A. 1974. Recherches de palynologie et de planctologie sur le Dévonien et quelques formations siluriennes dans le sud-est du Massif Armoricain. Mémoires de la Société géologique et minéralogique de Bretagne, 18, 1-248.

Moreau-Benoit, A. 1984. Acritarches et chitinozoaires du Dévonien moyen et superieur de Libye Occidentale. Review of Palaeobotany and Palynology, 43, 187-216.

Nautiyal, A.C. 1975. Occurrence of microplankton in the Middle Devonian rocks of Saskatchewan and Alberta, Canada. Current Science, 44, 851-853.

Nautiyal, A.C. 1976. Devonian acritarch distribution and paleolatitudes. Proceedings of the Indian National Science Academy, 42, 297-302.

Nautiyal, A.C. 1977. The paleogeographic distribution of Devonian acritarchs and biofacies belts. Journal of the Geological Society of India, 18, 53-64.

Newton, E.T. 1875. On "Tasmanite" and Australian "white coal." Geological Magazine, 12, 337-342.

Ottone, E.G. 1996. Devonian palynomorphs from the Los Monos Formation, Tarija Basin, Argentina. Palynology, 20, 105-155.

Paris, F. 1981. Les Chitinozoaires dans le Paléozoïque du sud-ouest de l'Europe (cadregéologique-étude systématique-biostratigraphie). Mémoire de la Société géologique et minéralogique de Bretagne, Rennes, 26, 1-496.

Paris, F., Yngve, G., Nestor, V. and Lakova, I. 1999. A revised chitinozoan classification. Journal of Paleontology, 73, 549-570.

Pascher, A. 1914. Über Flagellaten und Algen. Deutsche Botanische Gesellschaft, Berichte, 32, 136-160.

Peppers, R.A. and Damberger, H.H. 1969. Palynology and petrography of a Middle Devonian coal in Illinois. Illinois State Geological Survey, Circular, 445, 1-36.

Pereira, Z., Clayton, G. and Oliveira, J.T. 1994. Palynostratigraphy of the Devonian-Carboniferous boundary in southwest Portugal. Annales de la Société Géologique de Belgique, 117, 189-199.

Pereira, Z., Matos, J., Fernandes, P. and Oliveira, J.T. 2008. Palynostratigraphy and systematic palynology of the Devonian and Carboniferous successions of the South Portuguese Zone, Portugal. Memórias Geológicas do 
Wicander, R. and Playford, G., 2017. Organic-walled microphytoplankton assemblage... Boletín Geológico y Minero, 128 (4): $839-883$

Instituto Nacional de Engenharia, Tecnologia e Inovação, $34,1-181$.

Playford, G. 1977. Lower to Middle Devonian acritarchs of the Moose River Basin, Ontario. Geological Survey of Canada, Bulletin, 279, 1-87.

Playford, G. 1981. Late Devonian acritarchs from the Gneudna Formation in the western Carnarvon Basin, Western Australia. Géobios, 14, 145-171.

Playford, G. and Dring, R.S. 1981. Late Devonian acritarchs from the Carnarvon Basin, Western Australia. Special Papers in Palaeontology, 27, 1-78.

Playford, G. and McGregor, D.C. 1993. Miospores and organic-walled microphytoplankton of DevonianCarboniferous boundary beds (Bakken Formation), southern Saskatchewan: a systematic and stratigraphic appraisal. Geological Survey of Canada, Bulletin, 445, 1107.

Playford, G. and Wicander, R. 2006. Organic-walled microphytoplankton of the Sylvan Shale (Richmondian: Upper Ordovician), Arbuckle Mountains, southern Oklahoma, U.S.A. Oklahoma Geological Survey, Bulletin, 148, 1-116.

Pöthe de Baldis, E.D. 1974. El microplancton del Dévonico medio de Paraguay. Revista Española de Micropaleontología, 6, 367-379.

Pöthe de Baldis, E.D. 1975. Microplancton de la formacion Los Espejos provincia de San Juan, Republica Argentina. Revista Española de Micropaleontología, 7, 507-518.

Pöthe de Baldis, E.D. 1977. Paleomicroplancton adicional del Devonico Inferior de Uruguay. Revista Española de Micropaleontología, 9, 235-250.

Pöthe de Baldis, E.D. 1979. Acritarcos y quitinozoos del Devónico superior de Paraguay. Palinología, número extraordinario, 1, 161-177.

Reaugh, A.B. 1978. A new species of Cymatiosphaera (Acritarcha) with constant field tabulation from the Devonian of Tennessee. Palaeontology, 21, 835-846.

Rubinstein, C.V. 1999. Primer registro palinológico de la Formación Punta Negra (Devónico Medio-Superior), de la Precordillera de San Juan, Argentina. $10^{\circ}$ Simposio Argentino de Paleobotánica y Palinología (Buenos Aires), Publicación Especial, 6, 13-18.

Rubinstein, C.V. 2000. Middle Devonian palynomorphs from the San Juan Precordillera, Argentina: biostratigraphy and paleobiogeography. Internationale Congresso Ibérico de Paleontologia/XVI Jornadas de la Sociedad Española de Paleontología VIII International Meeting of IGCP 421, 274-275.

Sandford, B.V. 1967. Devonian of Ontario and Michigan. In: Oswald, D.H. (ed.), Proceedings of the International Symposium on the Devonian System, Calgary (1967), volume 1. Alberta Society of Petroleum Geologists, 973999.

Sarjeant, W.A.S. 1968. Microplankton from the Upper Callovian and Lower Oxfordian of Normany. Revue de Micropaléontologie, 10, 221-242.

Sarjeant, W.A.S. and Stancliffe, R.P.W. 1994. The Micrhystridium and Veryhachium complexes (Acritarcha: Acanthomorphitae and
Polygonomorphitae): a taxonomic reconsideration. Micropaleontology, 40, 1-77.

Sarjeant, W.A.S. and Stancliffe, R.P.W. 1996. The acritarch genus Polygonium Vavrdová emend Sarjeant and Stancliffe 1994: a reassessment of its constituent species. Annales de la Société géologique de Belgique, 117, 355-369.

Sarjeant, W.A.S. and Stancliffe, R.P.W. 2000. Acritarch taxonomy: certain controverted questions. Modern Geology, 24, 159-176.

Sarmiento, R. 1957. Microfossil zonation of Mancos Group. American Association of Petroleum Geologists, Bulletin, 41, 1683-1693.

Scotese, C.R. and McKerrow, W.S. 1990. Revised world maps and introduction. In: McKerrow, W.S. and Scotese, C.R. (eds.), Palaeozoic Palaeogeography and Biogeography. Geological Society of London, Memoirs, $12,1-21$.

Servais, T., Vecoli, M., Jun Li, Molyneux, S.G., Raevskaya, E.G. and Rubinstein, C.V. 2007. The acritarch genus Veryhachium Deunff 1954: taxonomic evaluation and first appearance. Palynology, 31, 191-203.

Sheshegova, L.I. 1971. Akritarkhi paleozoya. In: Vozzhennikova,T.F. (ed.), Vodozosli Paleozoya i Mezozoya Sibiri. K III Mezhdunarodnai Palinologicheskai Konferentsii Novosibirsk. Izdatelstvo Nauka, Moskva, 935.

Smith, N.D. and Saunders, R.S. 1970. Paleoenvironments and their control of acritarch distribution in the Silurian of east-central Pennsylvania. Journal of Sedimentary Petrology, 40, 324-333.

Staplin, F.L. 1961. Reef-controlled distribution of Devonian microplankton in Alberta. Palaeontology, 4, 392-424.

Staplin, F.L., Jansonius, J. and Pocock, S.A.J. 1965. Evaluation of some acritarchous hystrichosphere genera. Neues Jahrbuch für Geologie und Paläontologie, Abhandlungen, 123, 167-201.

Stockmans, F. and Willière, Y. 1960. Hystrichosphères du Dévonien belge (Sondage de l'Asile d'aliénés à Tournai). Senckenbergiana Lethaea, 41, 1-11.

Stockmans, F. and Willière, Y. 1962a. Hystrichosphères du Dévonien belge (sondage de l'Asile d'aliénés à Tournai). Bulletin de la Société belge de géologie, de paléontologie et d'hydrologie, 71, 41-77.

Stockmans, F. and Willière, Y. 1962b. Hystrichosphères du Dévonien belge (Sondage de Wépion). Bulletin de la Société belge de géologie, de paléontologie et d'hydrologie, 71, 83-99.

Stockmans, F. and Willière, Y. 1963. Les Hystrichosphères ou mieux les Acritarches du Silurien belge. Sondage de la Brasserie Lust à Courtrai (Kortrijk). Bulletin de la Société belge de géologie, de paléontologie et d'hydrologie, 71, 450-481.

Stockmans, F. and Willière, Y. 1969. Acritarches du Famennien inférieur. Académie royale de Belgique, Classe des sciences, Memoires, 38, 1-63.

Stockmans, F. and Willière, Y. 1974. Acritarches de la "Tranché de Senzeille" (Frasnien supérieur et Famennien inférieur). Académie royale de Belgique, Classe des sciences, Memoires, 41, 1-79. 
Stricanne, L., Munnecke, A., Pross, J. and Servais, T. 2004. Acritarch distribution along an inshore-offshore transect in the Gorstian (lower Ludlow) of Gotland, Sweden. Review of Palaeobotany and Palynology, 130, 195-216.

Stumm, E.C., Kellum, L.B. and Wright, J.D. 1956. Devonian strata of the London-Sarnia area southwestern Ontario. Michigan Geological Society, Annual Field Trip Guidebook.

Thusu, B. 1972. Depositional environments of the Rochester Formation in southern Ontario, Canada. Journal of Sedimentary Petrology, 42, 930-934.

Thusu, B. 1973a. Acritarchs of the Middle Silurian Rochester Formation of southern Ontario. Palaeontology, 16, 799826.

Thusu, B. 1973b. Acritarches provenant de I'llion Shale (Wenlockien), Utica, New York. Revue de Micropaléontologie, 16, 137-146.

Thusu, B. and Zenger, D.H. 1974. Middle Silurian acritarchs in the upper type Clinton Group, east-central New York. Journal of Paleontology, 48, 840-843.

Turnau, E. and Racki, G. 1999. Givetian palynostratigraphy and palynofacies: new data from the Bodzentyn Syncline (Holy Cross Mountains, central Poland). Review of Palaeobotany and Palynology, 106, 237-271.

Upshaw, C.F. 1964. Palynological zonation of the Upper Cretaceous Frontier Formation near Dubois, Wyoming. In: Cross, A.T. (ed.), Palynology in Oil Exploration. Society of Economic Paleontologists and Mineralogists, Special Publication, 11, 153-168.

Urban J.B. 1972. A reexamination of Chitinozoa from the Cedar Valley Formation of lowa with observations on their morphology and distribution. Bulletins of American Paleontology, 1-43.

Uyeno, T.T., Telford, P.G. and Sanford, B.V. 1982. Devonian conodonts and stratigraphy of southwestern Ontario. Geological Survey of Canada, Bulletin, 332, 1-32.

Vavrdová, M. 1966. Palaeozoic microplankton from Central Bohemia. Asopis pro Mineralogii a Geologii, 11, 409-414.

Vavrdová, M., Isaacson, P.E., Díaz, E. and Bek, J. 1993. Devonian-Carboniferous boundary at Lake Titikaka, Bolivia: Preliminary palynological results. XII Congrès International de la Stratigraphie et Géologie du Carbonifère et Permien, Comptes rendus, 1, 127-160.

Vavrdová, M., Bek, J., Dufka, P. and Isaacson, P.E. 1996. Palynology of the Devonian (Lochkovian to Tournaisian) sequence, Madre de Díos Basin, northern Bolivia. Vêstnik Ceského geologického ústavu, 71, 333-350.

Vecoli, M. 2000. Palaeoenvironmental interpretation of microphytoplankton diversity trends in the Cambrian-Ordovician of the northern Sahara Platform. Palaeogeography, Palaeoclimatology, Palaeoecology, 160, 329-346.

Wetzel, O. 1933. Die in organischer Substanz erhltenen Mikrofossilien des baltischen Kreide-Feuersteins mit einem Sedimentpetrographischen und stratigraphischen Anhang. Palaeontographica, Abteilung B, 78, 1-110.

Wicander, E.R. 1974. Upper Devonian-Lower Mississippian acritarchs and prasinophycean algae from Ohio, U.S.A. Palaeontographica, Abteilung B, 148, 9-43.

Wicander, E.R. and Loeblich, A.R., Jr. 1977. Organic-walled microphytoplankton and its stratigraphic significance from the Upper Devonian Antrim Shale, Indiana, U.S.A. Palaeontographica, Abteilung B, 160, 129-165.

Wicander, R. 1983. A catalog and biostratigraphic distribution of North American Devonian acritarchs. American Association of Stratigraphic Palynologists Contributions Series, 10, 1-133.

Wicander, R. 1984. Middle Devonian acritarch biostratigraphy of North America. Journal of Micropaleontology, 3, 19-24.

Wicander, R. 1986. Lower Devonian (Gedinnian) acritarchs from the Haragan Formation, Oklahoma, U.S.A. Review of Palaeobotany and Palynology, 47, 327-365.

Wicander, R. and Playford, G. 1985. Acritarchs and spores from the Upper Devonian Lime Creek Formation, lowa, U.S.A. Micropaleontology, 31, 97-138.

Wicander, R. and Playford, G. 2013. Marine and terrestrial palynofloras from transitional Devonian-Mississippian strata, Illinois Basin, U.S.A. Boletín Geológico y Minero, 124, 589-637.

Wicander, R. and Wood, G.D. 1981. Systematics and biostratigraphy of the organic-walled microphytoplankton from the Middle Devonian (Givetian) Silica Formation, Ohio, U.S.A. American Association of Stratigraphic Palynologists Contributions Series, 8, 1-137.

Wicander, R. and Wood, G.D. 1997. The use of microphytoplankton and chitinozoans for interpreting transgressive/regressive cycles in the Rapid Member of the Cedar Valley Formation (Middle Devonian), lowa. Review of Palaeobotany and Palynology, 98, 125-152.

Wicander, R. and Wright, R.P. 1983. Organic-walled microphytoplankton abundance and stratigraphic distribution from the Middle Devonian Columbus and Delaware Limestones of the Hamilton Quarry, Marion County, Ohio. Ohio Journal of Science, 83, 2-13.

Wicander, R., Playford, G. and Robertson, E.B. 1999. Stratigraphic and paleogeographic significance of an Upper Ordovician acritarch flora from the Maquoketa Shale, northeastern Missouri, U.S.A. Journal of Paleontology, Memoir, 51, 1-38.

Wicander, R., Clayton, G., Marshall, J.E.A., Troth, I. and Racey, A. 2011. Was the latest Devonian glaciation a multiple event? New palynological evidence from Bolivia. Palaeogeography, Palaeoclimatology, Palaeoecology, 305, 75-83.

Winder, C.G. and Sanford, B.V. 1972. Stratigraphy and paleontology of the Paleozoic rocks of southern Ontario: Excursion. XXIV International Geological Congress, Montreal, Québec. Excursion A45-C45.

Wood, G.D. 1974. Chitinozoa of the Silica Formation (Middle Devonian, Ohio): vesicle ornamentation and paleoecology. Publications of the Museum - Michigan State University Paleontological Series, 1, 127-162.

Wood, G.D. 1984. A stratigraphic, paleoecologic and paleobiogeographic review of the acritarchs Umbellasphaeridium deflandrei and Umbellasphaeridium saharicum. In: Sutherland, P.K. and Manger, W.L. (eds.), Biostratigraphy, Ninth International Congress on Carboniferous Stratigraphy and Geology. 
Southern Illinois University Press, Urbana, Illinois, 191211.

Wood, G.D. 1986. Some Middle Devonian (Givetian) chitinozoans and acritarchs from New York State: preliminary results. In: Miller, M.A. (ed.), A field excursion to Trenton Group (Middle and Upper Ordovician) and Hamilton Group (Middle Devonian) localities in New York, and a survey of their chitinozoans. American Association of Stratigraphic Palynologists Field Trip Guidebook, 104114.

Wood, G.D. and Clendening, J.A. 1985. Acritarchs and chitinozoans from the Middle Devonian (Givetian) Boyle Dolomite of Kentucky, U.S.A. Palynology, 9, 133-145.

Wright, J.D. and Wright, E.P. 1961. A study of the Middle
Devonian Widder Formation of southwestern Ontario. University of Michigan Museum of Paleontology, Contribution, 16, 287-300.

Yan Kui, Li Jun and Servais, T. 2013. An Early-Middle Ordovician acritarch and prasinophyte assemblage from Houping, Chongqing city, South China: biostratigraphical and palaeonvironmental implications. Review of Palaeobotany and Palynology, 198, 110-133.

Zhu Huaicheng, Wicander, R. and Marshall, J.E.A. 2008. Biostratigraphic and paleogeographic significance of a palynological assemblage from the Middle Devonian Ulusubasite Formation, eastern Junggar Basin, Xinjiang, China. Review of Palaeobotany and Palynology, 152, 141-157.

Recibido: septiembre 2016

Revisado: noviembre 2016

Aceptado: enero 2017

Publicado: diciembre 2017 
Wicander, R. and Playford, G., 2017. Organic-walled microphytoplankton assemblage... Boletín Geológico y Minero, 128 (4): $839-883$

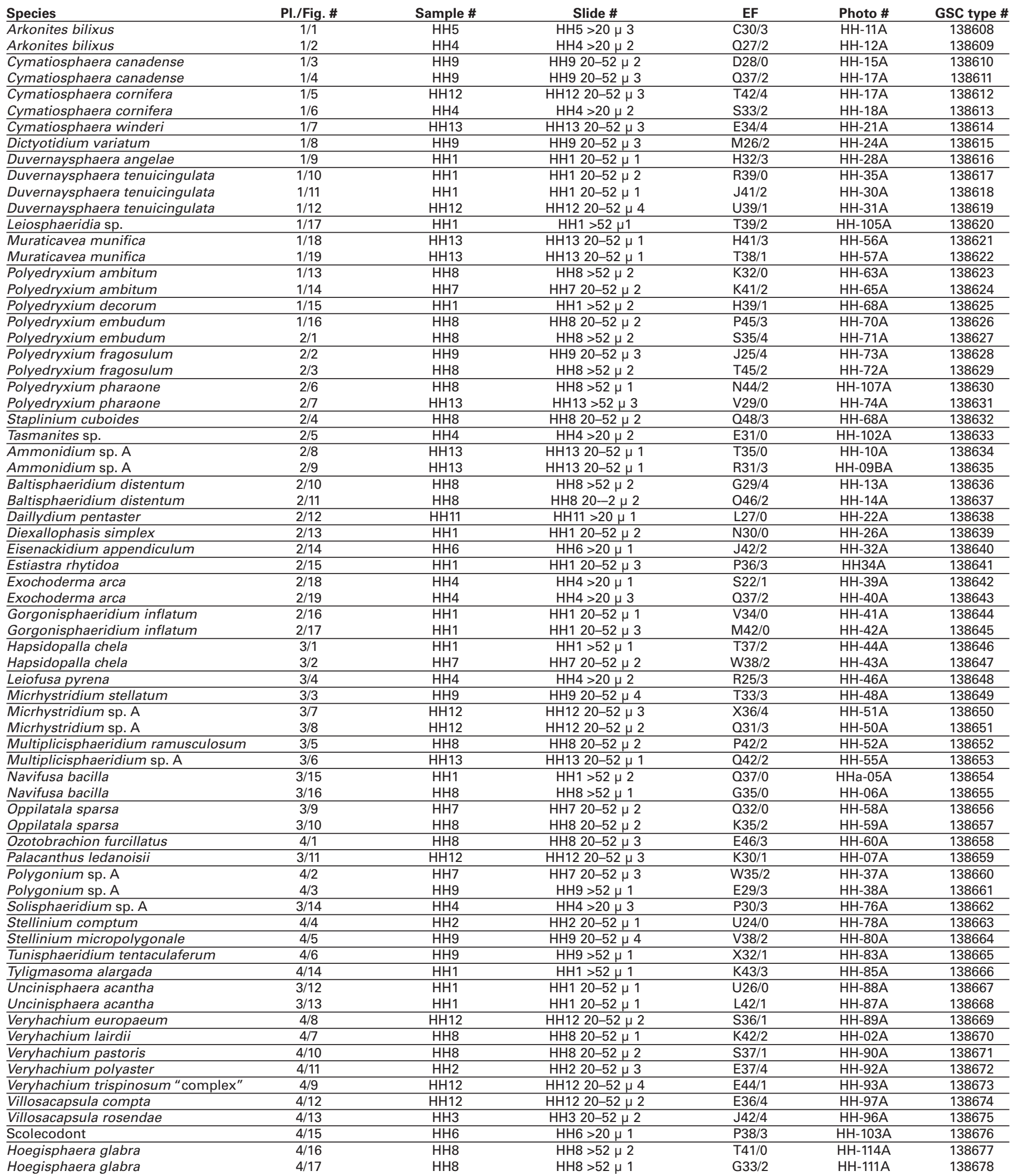

Appendix 1. Inventory of illustrated specimens (hypotypes). Slide locations of individual specimens are specified by coordinates derived from a standard England Finder ${ }^{\mathrm{TM}}$ (EF) slide. Specimen catalogue numbers (GSC Type 138608 to GSC Type 138678 inclusive) are those of the permanent repository: Geological Survey of Canada, National Invertebrate and Plant Type Fossil Collection, 601 Booth Street, Ottawa, Ontario, Canada. 